\title{
WPS3548
}

\section{Wage Determination in Northeast Brazil}

\author{
By
}

\section{Dorte Verner ${ }^{1}$}

World Bank Policy Research Working Paper 3548, March 2005

The Policy Research Working Paper Series disseminates the findings of work in progress to encourage the exchange of ideas about development issues. An objective of the series is to get the findings out quickly, even if the presentations are less than fully polished. The papers carry the names of the authors and should be cited accordingly. The findings, interpretations, and conclusions expressed in this paper are entirely those of the authors. They do not necessarily represent the view of the World Bank, its Executive Directors, or the countries they represent. Policy Research Working Papers are available online at http://econ.worldbank.org.

\footnotetext{
${ }^{1}$ I would like to thank Norbert M. Fiess for helpful comments and Nicolei Kristensen for excellent research assistance. The views, findings, interpretations, and conclusions expressed here are those of the author only, and should not be associated with the World Bank or its member countries.
} 


\begin{abstract}
This paper analyzes the labor markets in the states of Pernambuco, Bahia, Ceará, and the Northeast region of Brazil. The findings show a rather heterogeneous impact pattern of individual characteristics on monthly wages across the wage distribution. That is, the magnitude of the affect of a wage determinant is different depending on whether the worker is placed in the lower, median or top of the wage distribution. The findings reveal that education is key. Basic schooling matters for all four geographical areas and across the income distribution. However, poor workers are awarded lower returns than their richer peers and in Bahia and Ceará, the poor do not obtain any returns to basic schooling. Furthermore, the impact of 5-8 or 9-11 years of education is larger than that of 1-4 years of completed education. The returns obtained by a median worker are higher in Ceará and Pernambuco than in Bahia. Finally, completed tertiary education offers the largest returns of all levels of education; the median worker receives a premium of 105, 249, and 216 percent in Ceará, Pernambuco, and Bahia, respectively. Hence, one direct policy implication is to increase the quality of education, in particular in poorer neighborhoods.

Experience impacts positively on wages and it is increasing with age until workers reach 50 years of age. However, returns to experience are falling significantly across the wage distribution. For the poor and younger generations, experience contributes more to wages than education. The occupation of workers is important for wage determination; all workers in the included occupational groups are paid more than workers engaged in agricultural activities. Workers employed as technicians or administrators obtain the highest returns. The white/non-white wage disparity reveals that white workers are paid 17 percent more than their non-white co-workers, taking into account other characteristics. Gender disparities are large in the Northeast and heterogeneous across the wage distribution. The time spent in the current state impacts adversely on wages. That is, those that have stayed earn, on average, less than the newcomers. There are no considerable differences between male and female workers. Union membership has a positive impact on workers' wages.
\end{abstract}




\section{Introduction}

The Northeast Brazil is home to most of Brazil's poor people. It is well known that the main determining factors of the level of poverty of a state, region, or country lie in the way it uses and remunerates available human resources. Moreover, the more efficient the society is in allocating resources to economic activities, the lower the level of poverty. This allocation is mainly taking place in the labor markets, and, therefore, payment is highly dependent on the functioning of these markets. In Brazil the two most important labor market inefficiencies are: (1) the economy cannot supply employment to all in the active population, thus creating unemployment or underemployment (employment in low-quality jobs); and (2) discrimination manifested by under-compensation and underutilization of certain groups of employed workers.

This paper looks at changing ideas on how to analyze the factors behind, and the impact of such wages, or more precisely, what determines wages in Northeast Brazil. Furthermore, the paper investigates whether there is a difference between low and highpaid workers. These questions are analyzed by comparison of the wage determination process in four areas: the Northeast region as a whole, and three individual states, namely, Pernambuco, Ceará, and Bahia. The wage determination model is gauged by household data (PNAD) throughout the analysis and the quantile regression methodology is applied. This methodology characterizes the distribution of wages in more detail than traditional ordinary least squares (OLS) and two stage least squares (2SLS) regressions, as it makes it possible to break down the wage determination process across the entire wage distribution. Additionally, workers are allocated in different groups with different characteristics. Wages are compared across workers organized by gender, education, race, and geographical location.

So far, very little research has been done on labor markets in Northeast Brazil and even less so at the state level. Barros and Mendonça (1997) study wages in the Northeast and find that the average impact on wages of completed basic education is lower than that of secondary and superior education in 1987 and 1990. Furthermore, the comparison of the Northeast to São Paulo reveals that the effect on wages is lower for the second part of primary education and higher for the secondary and tertiary in the Northeast. The tendency shows increasing returns over time for secondary and tertiary education. Finally, the paper shows that returns are higher for whites than non-whites, controlling for education, age, gender, and residence area.

This paper analyzes for each quantile, each state and for the Northeast region, whether the impact of various individual characteristics on wages is homogeneous both across the wage distribution in a particular state or region, and across states and regions. The findings indicate that wages are by no means determined in the same way across states and regions, and for high and low-paid workers. Moreover, the data sample reveals substantial heterogeneity among Nordestinos and, hence, different impacts of the explanatory variables exist across the samples and wage distributions. For example, the return to education is far larger in the upper-income quantiles than in the lower ones. Furthermore, the findings reveal that large differences also exist across the Northeastern states. For example, for the median worker the impact on wages of being employed in the formal sector is higher in Pernambuco and Bahia than in Ceará. 
The paper is organized as follows: Section 2 outlines labor market developments in the Northeast region. Section 3 describes the methodology and data used in this study. Section 4 presents descriptive analyses, and Section 5 presents the regression results. The last section concludes with a summary of findings. The appendices include the tables mentioned in the text, for example, A1 refers to the table 1 in Appendix A. .

\section{The Northeast Labor Market}

In the Northeast of Brazil, the labor market tendencies over the past decade indicate that: first, real wages fell; second, formal employment decreased; third, open unemployment increased; and, fourth, precarious and informal sector employment augmented. In the Northeast, formal employment declined 5.4 percent over the $1990 \mathrm{~s}$, which is about half of the national average of 10.0 percent (Oliveira and Guimarães Neto 1999). According to these authors the total number of lost jobs in the Northeast was 185,000. There exists a large degree of heterogeneity with in the Northeast, for example, in Pernambuco and Ceará, 10.0 and 1.1 percent, respectively, of the jobs were lost. The number of jobs lost is by far the largest in Pernambuco $(72,000)$, Bahia $(54,000)$ follows fairly close and Ceará lost 4,000 positions. These figures also reveal that the Pernambucan economy is far more formalized than other states in the Northeast region. Ceará grew faster than Pernambuco in the 90s, which may explain the relative low reduction in formal employment in the state.

In Pernambuco, industries hit the hardest in terms of jobs lost were food and beverages including sugar production (45,900 workers lost their jobs in the 1989-94 period, see Oliveira and Guimarães Neto 1999). The deregulation and the halt in the use of Proálcool as automobile fuel dramatically damaged the sugar industry. Despite the smaller dimensions, Pernambuco experienced a reduction in positions in other industrial sectors. In textiles the job loss (around 9,000), was mainly caused by increased competition and a reduction in aliquotas. Metal sectors were affected less than the previous two, but the sector still experienced a 5,300 job cut, mainly attributable to deregulation of steel prices, which set in motion a number of firm closings. In electronics and communications, 3,700 jobs were eliminated.

The reduction in the number of formal jobs did not cause a comparable increase in open unemployment in the Northeast as a whole or in the states individually. Rather the decline in formal jobs has set in motion job creation in the informal sector. The indicators for informal job creation show a 7, 1, and 1 percentage point increase in Pernambuco, Ceará, and Bahia, respectively, in the first half of the 1999s. Furthermore, in Pernambuco, urban open unemployment fell 28 percentage points in the same period, compared to 12 percentage points in Bahia and 0 percentage points in Ceará (Oliveira and Guimarães Neto 1999).

To obtain coverage by the Brazilian labor code, workers need a formal contract or signed working card (carteira assinada). In Brazil, as a whole, as well as in the Northeast states, the proportion of workers with a signed working card has fallen considerably in the 1990s. In Pernambuco, around 50 percent of workers had a signed 
card in 1990. In 1997, the number has dropped substantially and reached 30 percent: 25 percent for men and 36 percent for women.

One of the main labor market problems in the Northeast seems not to be the lack of job creation - the rate is around 2.5 percent in Recife, 3.0 percent in Fortaleza, and 2.4 percent in Salvador (Paes de Barros et al. 1999) — but rather the number of poor quality jobs that are being created in the states. These jobs are largely informal in nature and characterized by low pay, low productivity, bad working conditions, and high turnover.

\section{Methodology and Data}

This section is organized in three sub-sections addressing the economic model applied in the analysis, quantile regression techniques, and data.

\section{Economic model}

The underlying economic model used in the analysis will simply follow Mincer's (1974) human capital earnings function extended to control for a number of other variables that relate to location. In particular, we apply a semi-logarithmic framework that has the form:

$\ln y_{i}=\varphi\left(x_{i}, z_{i}\right)+u_{i}$

where $\ln \mathrm{y}_{\mathrm{i}}$ is the $\log$ of earnings or wages for an individual; $i, \mathrm{x}_{\mathrm{i}}$ is a measure of a number of personal characteristics, including human capital variables, ethnicity, etc.; and $\mathrm{Z}_{\mathrm{i}}$ represents location specific variables-for instance, metropolitan living. The functional form is left unspecified in equation (1). The empirical work makes extensive use of dummy variables in order to catch non-linearities in returns to years of schooling, tenure, and other quantitative variables. The last component, $\mathrm{u}_{\mathrm{i}}$, is a random disturbance term that captures unobserved characteristics.

\section{Quantile regressions}

Labor market studies usually make use of conditional mean regression estimators, such as ordinary least squares. This technique is subject to criticism because of several, usually heroic, assumptions underlying the approach. One is the assumption of homoskedasticity in the distribution of the error terms. If the sample is not completely homogenous, this approach, by forcing the parameters to be the same across the entire distribution of individuals may be too restrictive and may hide important information.

The method applied in this paper is quantile regression. The idea is that one can choose any quantile and thus obtain many different parameter estimates on the same variable. In this manner the entire conditional distribution can be explored. By testing whether coefficients for a given variable across different quantiles are significantly different, one implicitly also tests for conditional heteroskedasticity across the wage distribution. This is in particular interesting for developing countries such as Brazil 
where wage disparities are huge and returns to, for example, human capital may vary across the distribution.

The method has many other virtues apart from being robust to heteroskedasticity. When the error term is non-normal, for instance, quantile regression estimators may be more efficient than least square estimators. Furthermore, since the quantile regression objective function is a weighted sum of absolute deviations, one obtains a robust measure of location and, as a consequence; the estimated coefficient vector is not sensitive to outlier observations on the dependent variable. ${ }^{2}$

The main advantage of quantile regressions is the semi-parametric nature of the approach, which relaxes the restrictions on the parameters to be fixed across the entire distribution. Intuitively, quantile regression estimates convey information on wage differentials arising from non-observable characteristics among individuals otherwise observationally equivalent. In other words, by using quantile regressions, we can determine if individuals that rank in different positions in the conditional distribution (i.e., individuals that have higher or lower wages than predicted by observable characteristics) receive different premiums to education, tenure, or to other relevant observable variables.

Formally the method, first developed by Koenker and Basset (1978), can be formulated $\mathrm{as}^{3}$

$\mathrm{y}_{\mathrm{i}}=\mathrm{x}_{\mathrm{i}}^{\prime} \beta_{\theta}+\mathrm{u}_{\theta \mathrm{i}}=\operatorname{Quant}_{\theta}\left(\mathrm{y}_{\mathrm{i}} \mid \mathrm{x}_{\mathrm{i}}\right)=\mathrm{x}_{\mathrm{i}}^{\prime} \beta_{\theta}$

where Quant $\mathrm{\theta}_{\theta}\left(\mathrm{y}_{\mathrm{i}} \mid \mathrm{x}_{\mathrm{i}}\right)$ denotes the $\theta^{\text {th }}$ conditional quantile of $\mathrm{y}$ given $\mathrm{x}$, and $i$ denotes an index over all individuals, $i=1, \ldots, \mathrm{n}$.

In general, the $\theta^{\text {th }}$ sample quantile $(0<\theta<1)$ of $y$ solves

$$
\min _{\beta}=\frac{1}{n}\left\{\sum_{i: y_{i} \geq x_{i}^{\prime} \beta} \theta\left|y_{i}-x_{i}^{\prime} \beta\right|+\sum_{i: y_{i}<x_{i}^{\prime} \beta}(1-\theta)\left|y_{i}-x_{i}^{\prime} \beta\right|\right\}
$$

Buchinsky (1998) examines various estimators for the asymptotic covariance matrix and concludes that the design matrix bootstrap performs the best. In this paper, the standard

2 That is, if $y_{i}-x_{i}^{\prime} \hat{\beta}_{\theta}>0$, then $\mathrm{y}_{\mathrm{i}}$ can be increased toward $+\infty$, or if $y_{i}-x_{i}^{\prime} \hat{\beta}_{\theta}<0$, $\mathrm{y}_{\mathrm{i}}$ can be decreased toward $-\infty$, without altering the solution $\hat{\beta}_{\theta}$. In other words, it is not the magnitude of the dependent variable that matters but on which side of the estimated hyperplane the observation is. This is most easily seen by considering the first-order-condition, which can be shown to be given as (see Buchinsky 1998) $\frac{1}{n} \sum_{i=1}^{n}\left(\theta-\frac{1}{2}+\frac{1}{2} \operatorname{sgn}\left(y_{i}-x_{i}^{\prime} \hat{\beta}_{\theta}\right)\right) x_{i}=0$.

This can be seen both as a strength and weakness of the method. To the extent that a given outlier represents a feature of "the true" distribution of the population, one would prefer the estimator to be sensitive to such an outlier - at least to a certain degree.

${ }^{3}$ See Buchinsky (1998). 
errors are obtained by bootstrapping using 200 repetitions. This is in line with the literature.

\section{Data}

The analysis in this paper uses micro data from Pesquisa Nacional por Amostra de Domicilios - PNAD (the Brazilian annual National Household Survey) for 1997. This survey is an annual national household survey performed in the third quarter that interviews around 100,000 households every year. It is conducted by IBGE, the Brazilian Census Bureau, and began at national level in 1971 and underwent major revision between 1990 and 1992. The survey contains extensive information on personal characteristics, including information on income, labor force participation and educational attainment and attendance.

The wage is spatially deflated to compensate for differences in the average cost-ofliving across the country, according to the spatial price index by Ferreira and Barros (1999).

\section{Descriptive Analysis and Background Information}

This section presents background information on key variables for wage determination used in this study. The analysis considers different elements contributing to the wage determination: (1) human capital accumulation such as formal education, and experience; (2) ethnic background; (3) gender; (4) metropolitan, rural or urban living; (5) union membership; and, (6) occupation and sector of employment.

\section{Wages}

This subsection discusses unconditional wages and wage inequality. The individuals included in the analysis are those who reported that they were employed during the interview period and reported the amount earned. ${ }^{4}$ The applied wage data is calculated on a monthly basis. Table A1 supplies information on the number of observations and distribution of the different groups of variables for the four data samples - the Northeast, Bahia, Ceará, and Pernambuco. The number of observations varies over the samples; for example, the sample of workers in each of the three Northeastern states is below 2000.

The unconditional average monthly wages in Pernambuco is larger than in Bahia, Ceará and the Northeast as a whole (table A1 and A2). This may be due to higher average age and accumulated human capital of the sample workers in Pernambuco. The average number of years schooling calculated from the data studied are, by and large, in line with other data sources; namely, that the average is higher in Pernambuco (5.8 years) than in Bahia (5.3 years), Ceará (5.4 years) and in the Northeast region (5.6 years).

\footnotetext{
${ }^{4}$ Individuals that answered yes to question $\mathrm{v} 4705$ and reported a monthly prime income, that is, question v9532.
} 
The entire distribution of monthly wages for the four regions is shown in figures 1A-10A in appendix F. The plots indicate that the wage distribution follows a similar pattern in all four areas. Furthermore, the variation at each percentile is small (see figure 1A). In the following, the impact on the wage distribution of individual characteristics is discussed.

The wage distribution of workers belonging to different tenure groups is given in figure 2A. The plot reveals large differences from the median to the top of the distribution among tenure groups. As expected, workers with the highest tenure earn significantly more than other tenure groups, not accounting for any other individual characteristics as accounted or in the analysis. This is the case for all four areas. The wage dispersion for each percentile above the median is lower in Pernambuco than in Ceará and Bahia, indicating that tenure may be less important in the former state in the wage determination process than elsewhere. When comparing the level of earnings for each of the four samples, it turns out that workers placed above the 70 percentile in Pernambuco with 13 years or more of tenure, earn less than do workers in other states.

General experience seems to be an important factor in explaining wage differentials among workers, when only considering the experience level as the sole wage gap explanatory factor (see figure 3A). In particular, less experienced workers (below 20 years of age) are clearly being paid less than their older and more experienced peers. At the top of the distribution the wage gap is huge between workers with different experience levels.

Education plays an important role in the wage-setting process in all four regions (figure 4A). In particular, workers who have completed between 9 and 11 years of education and more than 12 years of education obtain a substantially higher wage than their less educated peers. The figures show that wages in Ceará for women with more than 9 years of completed education clearly exceed those obtained in Pernambuco and Bahia.

Trade-union members are clearly paid more than non-members all across the wage distributions. This finding holds for all samples (figure 5A). However, the data does not take into consideration that this group may also be more educated.

By occupational sector, the figures reveal that agricultural workers earn far less than non-agricultural sector workers. This finding holds for all states and all along the wage distributions (figures 6A-1 and 6A-2). Surprisingly, there does not seem to be much difference between secondary and tertiary sectors in any of the four samples. Hence, the earnings in industry and service are at the same level.

The wage distributions of the gender and racial groups are plotted in figures 9A and 10A. A gender gap is very pronounced from around the $20^{\text {th }}$ percentile and above, and favors males. This finding is homogeneous and of similar magnitude in all the four samples. By racial origin-white versus non-whites - the wage differential is less marked in Pernambuco than in other states. The racial gap is smaller in Pernambuco and tends to widen less rapidly across the wage distribution than elsewhere in the region. However, it still indicates that racial may be an important explanatory factor in the wage determination process. 


\section{Wage inequality}

For 1997, the percentiles for monthly wages are reported in table A3 for different groups of workers (union and non-union members, males and females, and whites and non-whites). Additionally, table A3 reports on wage inequality. The wage inequality measured by the 10 percent richest relative to the 10 percent poorest $(90 / 10)$ is very heterogeneous across the four regions - the Northeast, Bahia, Ceará, and Pernambuco. The wage inequality ratio 90/10 indicates how much more workers placed in the $90^{\text {th }}$ percentile earn relative to workers placed in the $10^{\text {th }}$ percentile of the wage distribution. The 90/10 ratio of 10 reveals that the richest 10 percent of the workers earn 10 times more than the poorest 10 percent, which is the case in the Northeast and Pernambuco. The number is slightly higher in Ceará (12.1) and a little lower in Bahia (8.6). The 99/10 ratio shows the most variation of the reported ratios. It is as high as 40 in Ceará, and 24 and 33 in Bahia and Pernambuco, respectively. The median worker $\left(50^{\text {th }}\right)$ earns around 300 percent more than the poor workers placed in the $10^{\text {th }}$ percentile in all the states and regions analyzed here. Furthermore, the 10 percent richest earn 3.6, 3.0, 3.8, and 3.3 times more than the median worker in the Northeast, Bahia, Ceará, and Pernambuco, respectively.

In Pernambuco and Bahia, the wage inequality, measured by the top of the distribution $\left(90^{\text {th }}\right)$ and the median $\left(50^{\text {th }}\right)$ relative to the 10 percent poorest, is larger among males than females and whites than non-whites. The results are different for Ceará where the wage dispersion is larger among women than men. Table A4 shows that in the Northeast education is an important wage-equalizing variable. The ratio of the $90^{\text {th }}$ percentile to the median falls from 3.5 for workers with non-completed education to 3.1 for workers with 12 or more years of completed education. In Bahia, Pernambuco, and Ceará, the ratio drops to $2.7,2.8$, and 3.1, respectively. Furthermore, the 90/50 ratio reveals that wages are more unequal in urban than in rural areas.

\section{Formal education and training}

Table A1 gives the distribution of completed education for workers in the four regions. In 1997, a large share of workers in the sample did not complete any level of formal education. In the Northeast region, 19 percent of the males and 14 percent of the females did not complete any level of education. For the individual states the pictures show that 16 percent in Bahia and Pernambuco, and 21 percent in Ceará did not complete any level of formal education. Again, in Pernambuco there are fewer people than elsewhere with no completed education. Thirty-one percent finished between one and four years (except 36 percent in Bahia). Only 9 percent in Ceará and Pernambuco, and 6 percent in Bahia completed more than 12 years of education. The data do not indicate any large discrepancies in the level of education between female and male workers.

Furthermore, non-white workers obtained a lower level of education than did white co-workers in all four samples. In the Northeast, the percentage of the population with higher education is 7 percentage points higher for whites than for non-whites. 


\section{Wage Quantile Regression Findings}

This section presents findings of the mean and quantile regressions for 1997. We use standard quantiles, namely the $10^{\text {th }}, 25^{\text {th }}, 50^{\text {th }}, 75^{\text {th }}$, and $90^{\text {th }}$ quantiles. The same wage equation is estimated for each of the four samples: (1) Pernambuco; (2) Bahia; (3) Ceará; and, (4) the Northeast. Furthermore, we analyze subgroups at different levels of education, of different genders, races, and urban-rural living.

Wages are modeled by using log monthly wages as the dependent variable. The general wage model contains explanatory variables in levels and allows for nonlinearities in the data. For example, the log wage equation is found to be non-linear in education and experience. This way of modeling wages indicates that returns to education and experience are not constant but decreasing over the life cycle. In addition, the model contains dummy variables that take the value of one if, for example, a worker holds a job in the formal sector, and zero otherwise. Such a dummy variable may reveal whether there is a wage premium related to the formal sector employment. Appendix C presents the estimated wage equations. The median regression specification explains between 31 and 35 percent of the variance in wages in the quantile regressions for the Northeast, Pernambuco, Bahia, and Ceará, see table D1 that shows the pseudo- $\mathrm{R}^{2}{ }^{5}$ In all samples the pseudo- $\mathrm{R}^{2}$ is rising with the increasing quantile; that is, more is being explained in the high-income quantiles than in the low-income quantiles of the wage distribution. ${ }^{6}$

In the four samples, all included explanatory variables have the expected signs. Very few included variables are not statistically significantly different from zero for all quantiles. Each explanatory variable will now be discussed in turn: (1) education; (2) experience; (3) labor market association; (4) occupation and sector; (5) gender and ethnicity; (6) state, metropolitan, rural versus urban living; and, (7) union membership.

\section{Education}

Human capital has proven to be important in enhancing long-term economic growth. ${ }^{7}$ A more educated workforce is likely to increase worker productivity, to be flexible and innovative, and to facilitate the adoption and use of new technologies. The increasing speed of technological change faced by firms today and international economic integration means that workers need to have more skills at higher levels in order for firms to be competitive. One reason for this is that more skilled employees can adjust more easily to changes in their firm's economic and technological environment than less skilled workers. ${ }^{8}$ Hence, low returns, or the complete lack of returns, are an

\footnotetext{
${ }^{5}$ The standard $\mathrm{R}^{2}$, which is based on the breakdown of the entire variation between the fitted and residual values, is incorrect for quantile regressions. Therefore, the so-called pseudo- $\mathrm{R}^{2}$ is used and it is defined as the squared correlation between original and fitted observations.

${ }^{6}$ The OLS regressions explain between 53 (Ceará) and 46 (Bahia) percent (see Table D2).

${ }^{7}$ See, for example, Barro (1991) and Mankiw, Romer, and Weil (1992).

${ }^{8}$ One issue that needs to be mentioned relates to the endogeneity of education in the regressions. There is vast evidence of a positive correlation between earnings and education. However, social scientists are
} 
obstacle to economic growth in the Northeast and its states. Furthermore, findings may indicate that large differences in the quality of education across regions within the Northeast are important. ${ }^{9}$

Knowledge about educational wage differentials or wage gaps serves at least three different purposes. First, wage differentials reveal the magnitude of incentives or returns obtained by workers acquiring education, and, hence, individual educational demand. Second, knowing the extent of economic returns to human capital makes it possible to access whether it is worth making this kind of investment instead of others. Third, wage differentials disclose how the labor market translates educational inequalities into wage inequalities, which is important information in the process of reducing the latter. Furthermore, educational returns link to some extent education to labor productivity and indicate the magnitude of the contribution of education to economic growth. Therefore, it is of interest to estimate the impact of different levels of education and experience on money wages. Furthermore, this analysis may indicate areas of education scarcity and hence areas for policy intervention.

This study confirms the findings of hundreds of other studies, namely that education plays an important role in the wage determination process. Better-educated individuals earn higher wages and work in more prestigious jobs than their less-educated peers.

Are returns to education homogeneous across the states and regions and constant over income distributions? According to the findings presented in table $\mathrm{C} 1$ and figures 1 to 4 , the answer is no to both questions. ${ }^{10}$ In this analysis, findings allow comparison for workers with no completed level of education (the reference group) or compared with their co-workers who have completed first part of primary school (1-4), second part of primary school (5-8), secondary school (9-11), and with those who completed tertiary school (12 or more years of education). ${ }^{11}$

In the Northeast of Brazil, I found that returns to $1-4,5-8,9-11$, and 12 or more years of completed education were statistically significantly different from zero and positive for all at the analyzed quantiles, controlling for other individual characteristics.

cautious to draw strong inference about the causal effect of education. In the absence of experimental evidence, it is tricky to recognize whether higher earnings observed for better educated employees are caused by their higher level of completed education, or whether employees with greater earnings capacity have chosen to acquire more education. Card (1998) surveys the literature on the causal relationship between education and earnings and finds that the average marginal returns to education is not much below the estimate that emerges from standard human capital earnings function studies. The PNAD data does not supply information which can be used to solve this problem.

${ }^{9}$ Measurement errors in schooling would be expected to lead to a downward bias in the OLS estimator of the relationship between schooling and wages, see Griliches (1979).

${ }^{10}$ Unmeasured ability and measurement error problems have been dealt with in the literature applying data on twins, see for example Card (1998) and Arias, Hollack, and Sosa (1999).

11 The so-called "sheepskin effect" states the existence of wage premiums for completing the final year of elementary school, high school, or university. Therefore, it has been argued that credentials such, as a school diploma or university degree are more important than years of schooling per se. That is one reason for not having a continuous education variable in the regressions. 
This finding means that having completed at least a few years of education contributes more to wages than not having completed any education at all. Moreover, the premium is: first, rapidly increasing with attained education. In the Northeast, a median worker experience an impact on wages of 24, 37, 55, and 197 percent for completed 1-4, 5-8, 911 , or 12 or more years of education, respectively. ${ }^{12}$ Better-educated individuals in the Northeast earn dramatically higher wages than do their less-educated counterparts. Second, the premium is increasing across quantiles. That is clearly seen by the following example. A poor worker $\left(10^{\text {th }}\right.$ quantile $)$ receives a 103 percent return to 12 years or more of completed education while a rich worker obtains 252 percent return, both relative to those who had not completed any level of education. Furthermore, this indicates that in the determination of returns to education there are other mechanisms at play than pure individual characteristics. One explanation for the difference in returns could be found in the quality of education achieved, i.e., that poor attended schools where teaching was of lower quality than schools attended by richer people; which the regression analysis does not capture. Another explanation relates to social capital, that is, who you know. Poor people do not benefit to the same degree as richer people from connections, recommendations, etc.

In the following, we look at returns to each level of completed education:

Basic schooling, having four years or less completed years of education, matters for all four geographical areas and across the income distribution except for the poorest in Bahia and Ceará (see figure 1$)$. The poor $\left(10^{\text {th }}\right.$ quantile) in Bahia and Ceará do not receive a wage premium when completing first part of primary education. One explanation may be the low number of observations since for the Northeast as a whole findings reveal that four years of completed education generate a return of 16 percent for the poorest. In the Northeast as a whole, the findings reveal a large degree of heterogeneity in returns to education across the wage distribution (see table F1 and figure $1)$. Workers in the low end of the wage distribution $\left(10^{\text {th }}\right.$ and $25^{\text {th }}$ quantiles $)$ obtain lower returns than workers in the top end $\left(75^{\text {th }}\right.$ and $90^{\text {th }}$ quantiles). Hence, workers with the same level of education are not compensated equally. In Pernambuco, a worker at the median receives a 43 percent return, and findings reveal that the poor $\left(10^{\text {th }}\right.$ quantile $)$ ) and also workers in the $75^{\text {th }}$ quantile receive the same return to $1-4$ years of completed education. But, workers placed in the $10^{\text {th }}, 50^{\text {th }}$ and $75^{\text {th }}$ quantile receive statistically significant higher returns than co-workers in the top end $\left(90^{\text {th }}\right.$ quantile $)$ where the returns are only 31 percent. In Bahia and Ceará, no statistically significant wage heterogeneity is present for workers with 1-4 years of education, except that the poor do not obtain any returns (see above).

${ }^{12}$ The percentage return is calculated as $(\exp ($ coefficient estimate $)-1) * 100$. 
Figure 1

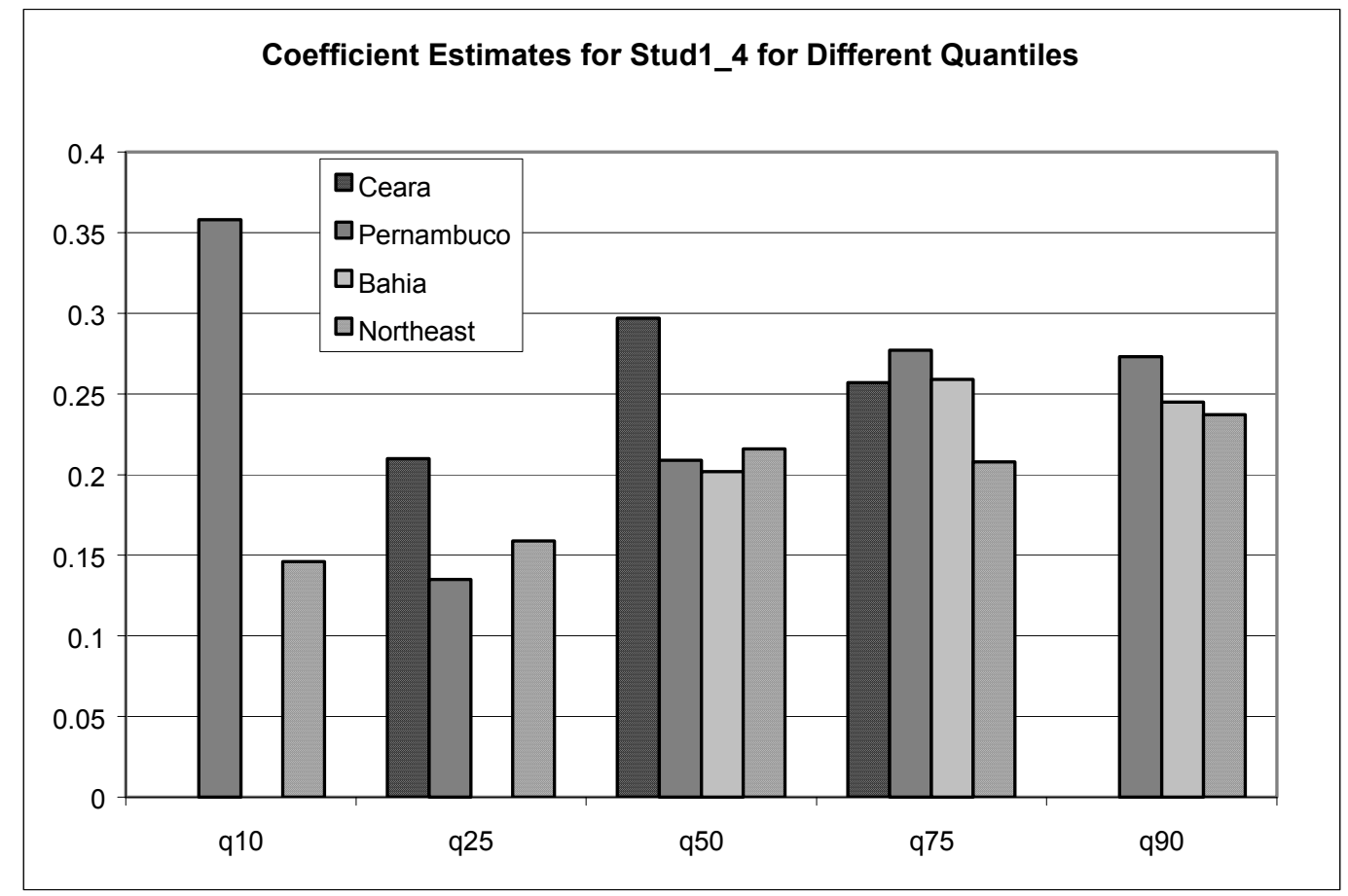

Data source: Author's calculation.

Second part of primary school also impacts wages significantly in Pernambuco and the Northeast region. The returns are larger in Pernambuco than elsewhere, and the poor are compensated similarly to the rich. The returns are higher for 5-8 years of education than for 1-4 years of education for all quantiles (see figure 2). This is also the case in Ceará and Bahia.

Secondary education impacts significantly on the wage distribution in all samples. Furthermore, in Pernambuco, Ceará, Bahia and the Northeast returns to secondary education (9-11 years) are present at all quantiles. The returns obtained by a median worker are higher in Ceará (84 percent) and Pernambuco (66 percent) than in Bahia (48 percent) (see figure 3). In Ceará returns are rapidly increasing across the distribution and the poor $\left(10^{\text {th }}\right.$ quantile) receive a 35 percent return and the rich $\left(90^{\text {th }}\right.$ quantile) a much higher, namely 93 percent return to completed secondary education. The same is true in Bahia. In Pernambuco, there is less variation across the distribution, and returns are high also in the low end of the wage distribution ( 80 percent) and in the high end returns are 92 percent. 
Figure 2

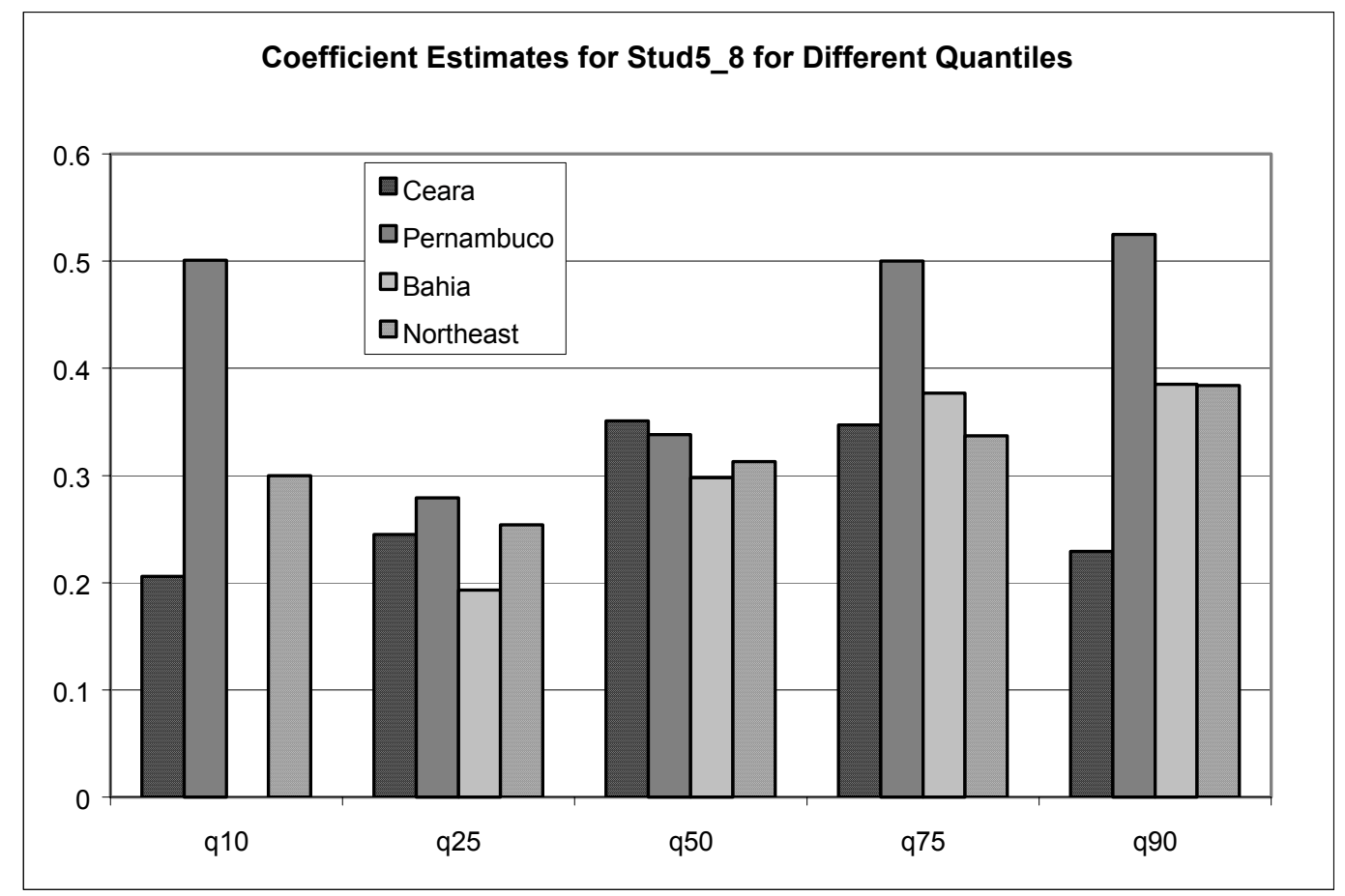

Data source: Author's calculation.

\section{Figure 3}

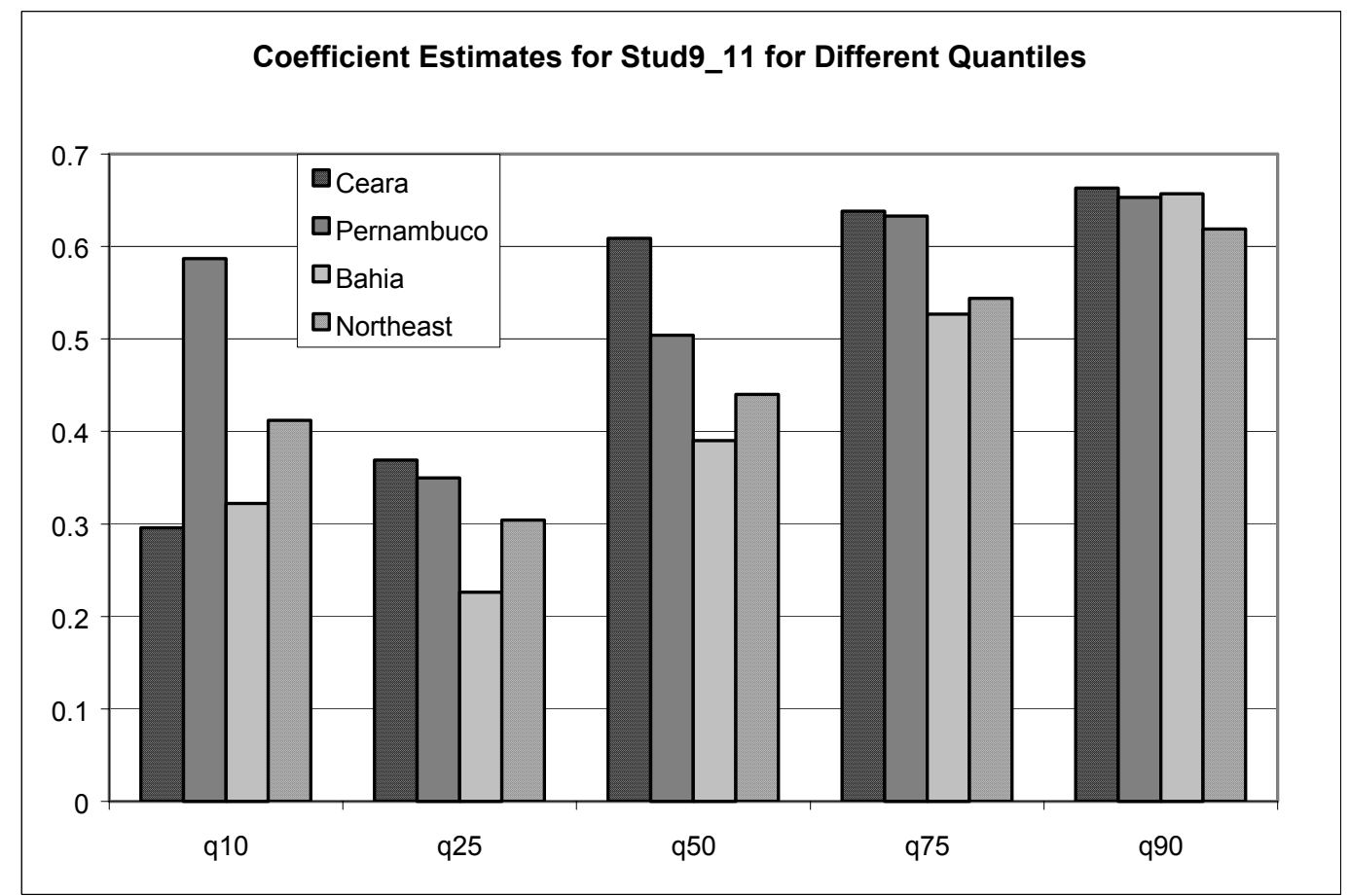

Data source: Author's calculation. 
For tertiary education (12 years or more of completed education), the findings show that the median worker receives a premium of 105, 249, and 216 percent in Ceará, Pernambuco, and Bahia, respectively (see figure 4). The test for equality of returns at various quantiles (which is also a test for homogeneity) is presented in Table F1. The findings reveal that workers placed in the $90^{\text {th }}$ quantile earn significantly higher returns to secondary and tertiary education than workers in the $10^{\text {th }}, 50^{\text {th }}$ and $75^{\text {th }}$ quantiles. One explanation for the lower returns at lower quantiles may relate to social capital. It is easier to obtain a "good" job when richer, since richer workers generally socialize with richer people that have better connections and information than poor people. Hence, poor people do not have the same access to high quality jobs as rich people. In addition, the findings reveal that Pernambuco pays higher returns than Bahia for all levels of education and Ceará and Pernambuco alternate for different quantiles and level of education.

Figure 4

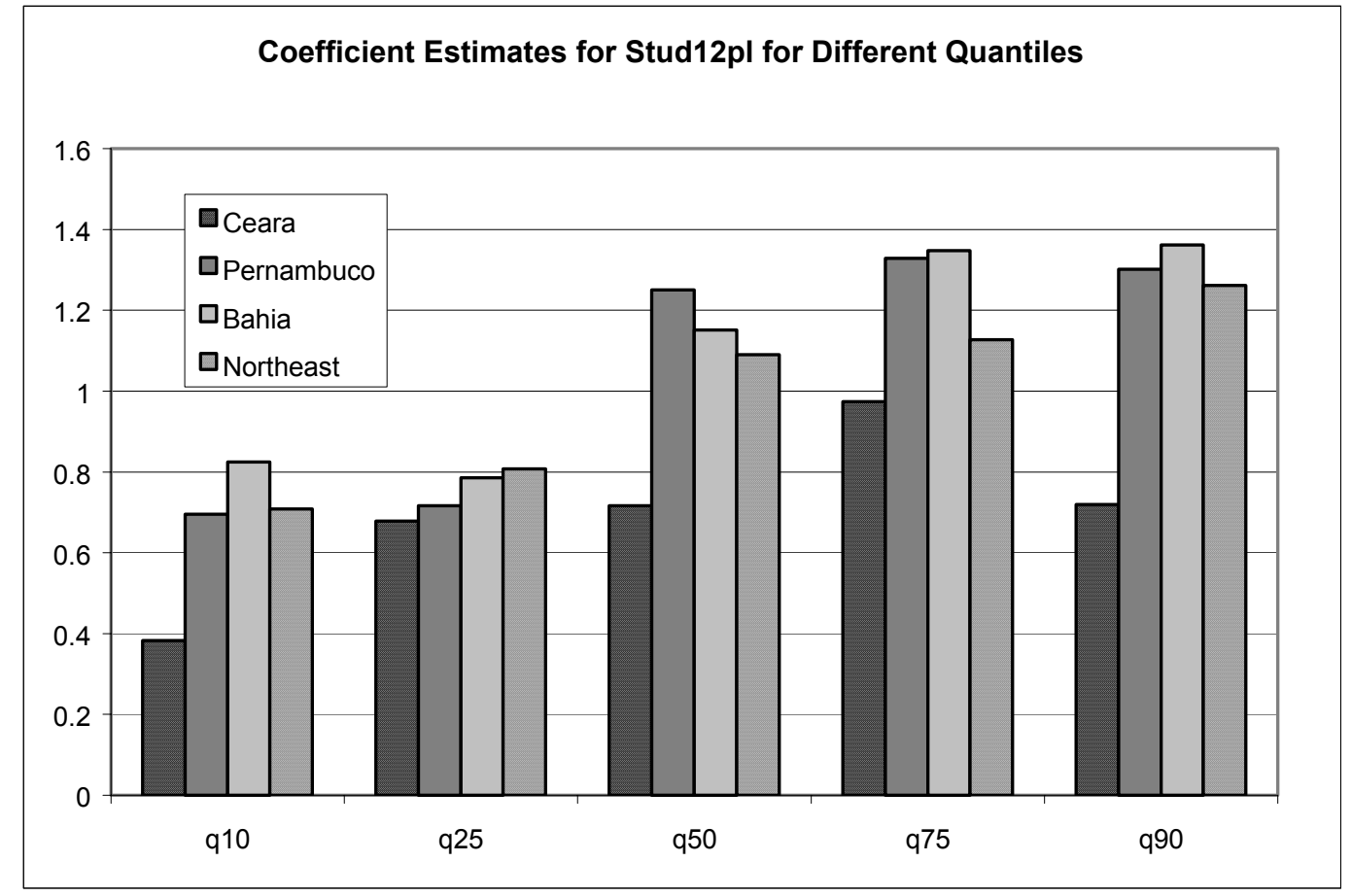

Data source: Author's calculation.

Gender differences related to education. In the following, the sample is disaggregated into two sub-samples: one for male and one for female workers (see tables $\mathrm{C} 2$ and $\mathrm{C} 3$ ). Education plays a very important role in determining income for both genders. For all four geographical samples the determinants of income differ substantially between the two groups. The income of male workers increases more rapidly than dies income of females with the level of completed education and experience. For instance in the Northeast, a median $\left(50^{\text {th }}\right)$ male worker who has completed between 9 and 11 years of education (secondary education) obtains returns of 65 percent while a female worker with the same characteristics only receives a 34 percent. The exception being that females with more than 12 years of studies (university education) receive a return at least equal to that obtained by their male colleagues. In the Northeast as a whole, encouraging or facilitating females to continue beyond the $11^{\text {th }}$ year 
of completed education will more than double the impact on wage. These findings suggest that, for all quantiles, university education delinks gender from wages.

\section{Experience}

There are several reasons for including experience characteristics in the analysis. One such reason is that a trained and educated workforce provides flexibility in adapting to changes in technology or other economic changes. Experience and years of schooling are widely used in analyses of wage determination (see Welch 1969, Mincer 1974, and Levy and Murnane 1992). Two measures of experience are included in this analysis, namely general and job-specific experience. The former is measured by the age of the worker and the latter by years of experience on the current job that is tenure.

Are returns to experience homogeneous across the population and over the life cycle? According to the findings presented in table $\mathrm{C} 1$, the answer is no to both questions.

General experience. The reference experience group is workers between 10 and 20 years old. The five age groups included in the regression models are 21-30, 31-40, 4150 , and 51 and above.

For Pernambuco, Ceará, Bahia and the Northeast region, the experience variables are statistically significantly different from zero and positive for all five reported quantiles and experience groups, controlling for other individual characteristics. These findings highly indicate that returns to experience are not constant throughout the life cycle. The impact of experience on wages is positive and increases with age until workers reach 50 years of age. Thereafter, the returns fall dramatically at all quantiles (table C1). One explanation may be that older workers adapt less easily to new technologies than do younger workers. Returns to experience are falling significantly across the wage distribution in Pernambuco, Ceará, Bahia, and the Northeast. Hence, the experience wage gap is largest at the lower quantiles. Workers located in the middle of the distribution $\left(50^{\text {th }}\right)$ and between 21 and 30 years of age receive premia ranging from 21 percent (Pernambuco) to 38 percent (Ceará) and 40 percent (Bahia). The variation within an age group and across quantiles is huge, and, in particular in Bahia, where the gap ranges from 67 percent in the $10^{\text {th }}$ quantile to 28 percent in the $90^{\text {th }}$ quantile. The variation in returns across the distribution decreases in all samples with increased experience. For the high age groups (51-70 year olds), the impact of experience on wages for a median worker range from 67 percent in Ceará to 56 percent in Bahia and 34 percent in Pernambuco. Interestingly, the general experience contributes more to wages than education in the younger generations placed in the lower end of the wage distribution in Pernambuco, Ceará, and Bahia. This compares to workers in the higher end of the wage distribution where the education impact on wages is by far larger than the experience impact.

Job-specific experience. The findings for experience or tenure obtained on-the-job differ from the findings for general experience (see table $\mathrm{C} 1$ ). The comparison group in this case is workers with less than one year of experience on-the-job. The four other groups included in the analysis are workers with more than 13 years, between 12 and 7, 6 and 3 , and 2 and 1 years of experience in their current job. 
In the Northeast the impact on wages of increased on-the-job experience is statistically significantly different from zero and positive. Furthermore, returns are monotonically increasing with on-the-job experience. This is the case in all quantiles in the wage distribution. A median worker in the Northeast receives a 34, 21, 15, and 4 percent premium for more than 13 years, between 12 and 7, 6 and 3, and 2 and 1 years of experience on-the-job, respectively, compared to a worker with less than one year of experience. In Pernambuco and Bahia, the job specific experience variable is insignificant for the lowest quantile $\left(10^{\text {th }}\right)$. This indicates that in these states the poor do not receive any premium for job-specific experience.

Workers with more than 13 years, between 12 and 7, and 6 and 3 years of experience in their current jobs earn a constant return across the wage distribution, except for between 3 and 6 years of experience and in the $10^{\text {th }}$ quantile in Bahia and in the $90^{\text {th }}$ quantile in Pernambuco, where it is insignificantly different from zero. The Pernambucan worker placed in the $50^{\text {th }}$ quantile earns for, more than 13 years, between 12 and 7, and 6 and 3 years of experience 53,28, and 17 percent more than a co-worker with less than a year on-the-job, respectively. The findings are similar for Bahia, but lower for Ceará (24, 28 and 13 percent, respectively).

Gender differences related to experience. To measure differences between men and women in the effect of experience on the determination of wages, I divide the sample into two sub-samples: one for males and one for females (see tables C2 and C3). The impact on wages of medium and high levels of experience (measured both by age and tenure in the job) is positive for both men and women, and significantly different from zero for all quantiles. Returns to experience, general as well as on-the-job, are higher for males than for females. Furthermore, returns to general experience increases faster for men than for women.

\section{Labor market association}

Labor market association is measured by the formality of a worker's job status. That is, whether a worker is engaged in the formal or informal sector. Workers with a signed working card (carteira assinada) I allocate to be in the formal sector.

In the Northeast region, workers who held a signed working card obtain statistically significant higher pay than their peers without a signed working card (see table C1). This finding appears in all four samples. For Pernambuco and Bahia, a median worker with a signed working card obtains a 34 percent higher wage premium than a non-signed working cardholder. The premium is generally lower for Ceará where a median worker with a signed working card only earns 18 percent more than a worker without a signed working card. For all samples, the premium declines across the wage distribution (see figure 5). That is, low wage earners benefit more in terms of wages from a signed working card than do high wage earners. In the Northeast, a worker placed in the $10^{\text {th }}$ quantile obtains a wage premium of 55 percent whereas a worker in the $90^{\text {th }}$ quantile only receives a 16 percent premium. These findings indicate that returns to formality in job position are not constant across states or across the wage distributions. The formal sector generally supplies higher quality jobs than the informal sector. Since higher quality may require more skills, the signed workbook may capture skill differences between the two groups of workers, which the other included variables do not capture. The wage gap 
between the formal and informal sector may also be caused by lower productivity in the informal sector relative to the formal sector, which is not captured by human capital or job specific information. Hence, workers in the informal sector are disadvantaged in at least two ways: first, they do not have access to social security or alike; and second, they obtain lower wages, which evidently does not compensate informal workers for the absence of social security. The informal sector workers are not only disfavored in terms of wages and social security, but they may also work in an environment where they are more exposed to the risk for accidents occurring, etc.

\section{Figure 5}

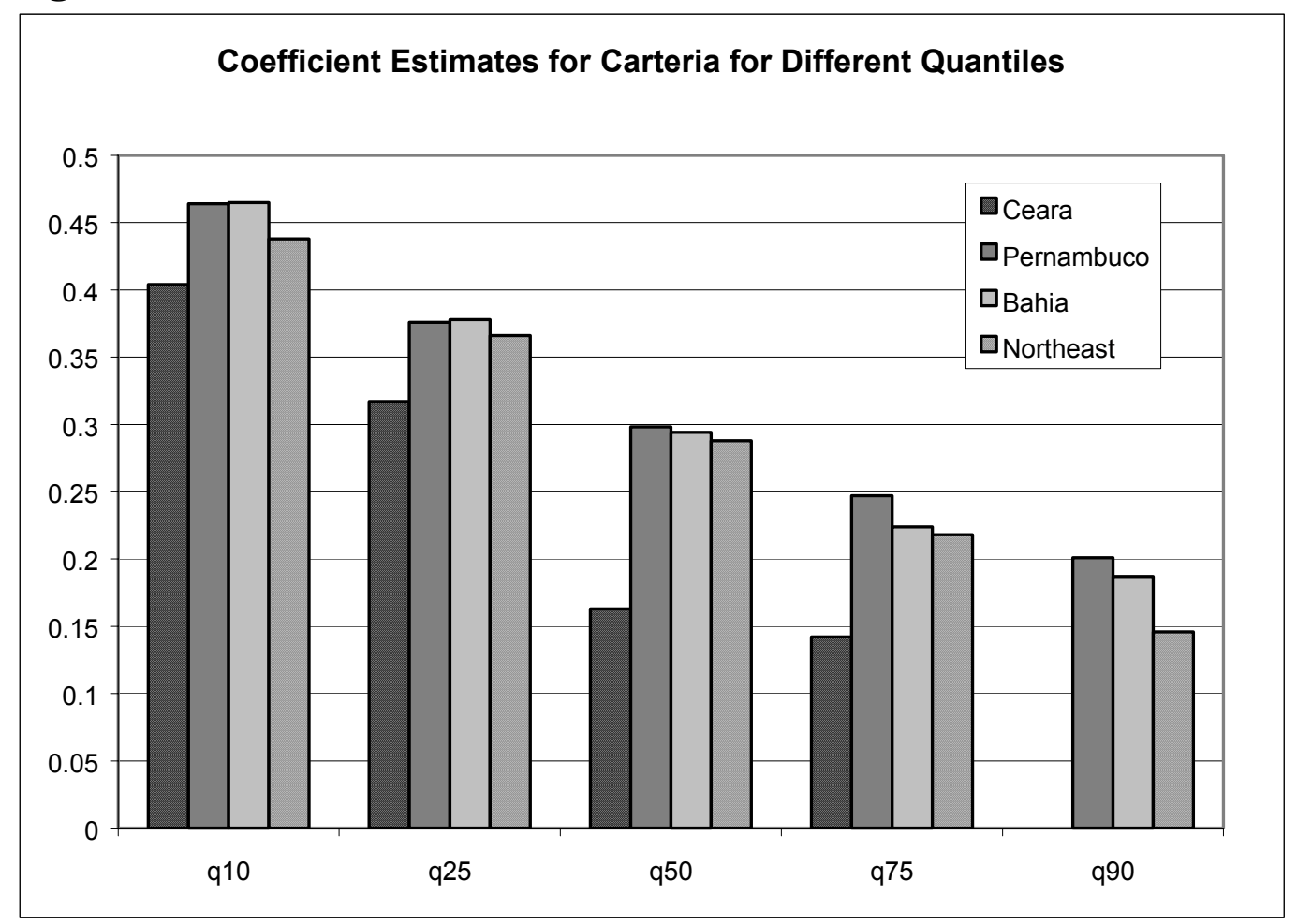

Data source: author's calculation.

Gender differences related to labor market association. In the Northeast, a worker in the lowest income quantile $\left(10^{\text {th }}\right)$ experiences an impact on wages of being in the formal sector of 68 and 44 percent for male and female, respectively. Returns are significantly different from zero at all quantiles. Both returns and gender difference are falling as income increases. This also holds in Bahia and Ceará. In Pernambuco females placed in the lowest end of the income distribution $\left(10^{\text {th }}\right)$ employed in the formal sector obtain a higher premium than their male colleagues. 


\section{Occupation and Sector}

The occupation of workers is also included in the determination of wages. Six occupation groups are introduced: (1) agriculture and agricultural products; (2) technician or administration; (3) transformation industry/manufacturing; (4) transport, communication, commerce, or trade; (5) service; and (6) other. The reference group in the analysis is agriculture and agricultural products.

In the Northeast all the included occupational groups are statistically significant and different from zero and positive. This indicates that workers in the above-mentioned occupation groups are paid more than workers engaged in agricultural activities. Workers employed as technician or as administrators obtain the highest return (for the median worker it is 93 percent), and workers in transport, communication, commerce, or trade receive the second highest return (64 percent), controlling for other factors such as level of human capital. Workers in the transformation industry or manufacturing obtain a 54 percent premium, and in service a 49 percent premium. Furthermore, the wage gap is constant across the distribution for all occupational groups. In Bahia, technicians and administrators obtain lower wage premium than colleagues in Pernambuco or Ceará. For the $90^{\text {th }}$ quantile, the premium is 54, 134 and 243 percent for Bahia, Pernambuco and Ceará, respectively. Hence, regarding occupation there exist substantial regional differences in the wage determination process.

Sector. The findings reveal that the sector of employment of a worker is important in the wage determination process. The agricultural sector (the primary sector) is compared to industry (the secondary sector) and services (the tertiary sector). Workers employed in industry in the Northeast are paid significantly less than their colleagues in the agricultural sector (except at the $90^{\text {th }}$ quantile). The wage gap is largest at the $50^{\text {th }}$ quantile (18 percent) and lowest at the $10^{\text {th }}$ quantile ( 3 percent).

The picture changes substantially when considering Pernambuco, Ceará, and Bahia separately. Here, there is no measurable difference between wages in the agricultural and industrial sectors, controlling for occupation and other individual characteristics. The same holds for the agricultural and service sectors (except for workers placed in the $25^{\text {th }}$ quantile who earn significantly more when employed in the agricultural sector in Bahia and Ceará).

Gender differences related to sector and occupation. A decomposition of the geographical sample into two sub-samples; one for males and one for females (see tables C2 and C3), discloses interesting differences with regard to sector of employment. For all geographical areas considered, the sector has no statistically insignificant impact on the wages for males. Conversely, the sector of employment impacts statistically significantly on female wages. In the Northeast, a median female worker in the tertiary sector receives 30 percent less than a female worker in the primary (agricultural) sector. The sector coefficients show a similar pattern for the individual regions (Pernambuco, Bahia, and Ceará), but are rarely statistically significant, which probably is due to the lower number of observations compared to the Northeast as a whole.

The impact of occupation also differs across gender. In the Northeast as a whole, Pernambuco and Ceará, working as a technician or administrator increases wages both 
for males and females. The coefficient is statistically significant for all quantiles in these three areas, except for the $10^{\text {th }}$ quantile in Pernambuco and Ceará (male and female) and in Pernambuco the $25^{\text {th }}$ quantile for female and $50^{\text {th }}$ quantile for male. The female premium clearly exceeds the premium obtained by males. For instance, in the Northeast, the median female administrator receives a premium of 142 percent while her male peers obtain a 65 percent premium.

\section{Race and Gender}

Discrimination at an individual level is said to arise if an otherwise identical person is treated differently by virtue of that person's ethnicity or gender, and ethnicity or gender by themselves have no direct effect on productivity. Under perfect competition in the capital and labor markets, equivalent employees in equivalent jobs are compensated equally, that is, there is no discrimination.

The estimation of discrimination is difficult. Worker productivity is seldom observed directly, so data must be used to proxy for the relevant productivity characteristics. The main debate occurs over whether relevant omitted characteristics differ between ethnicity, and between gender, and whether certain included characteristics capture productivity differences or instead are a proxy for ethnicity or gender. The following section reports findings on gender and ethnic differences in data.

Race. The quantile regression findings indicate that the racial background of an employee is important in Brazil, but less so in the Northeast and the three states (see table $\mathrm{C} 1$ ); this is measured by the size of the estimated coefficients on the variable white. These findings hold across quantiles, controlling for the level of human capital and other worker characteristics.

The wages of white relative to non-white workers are statistically significantly different from zero and positive for all quantiles in the Northeast and the three states, except in two cases: the $10^{\text {th }}$ quantile in Ceará and the $75^{\text {th }}$ quantile in Bahia (table C1). ${ }^{13}$ Furthermore, the white/non-white wage gap is constant across the distributions (see table F1 that presents statistical tests thereof and figure 6). Differences in wages are hence at play in both the upper and lower quantiles in the wage distribution. This indicates that white Brazilians workers generally are paid more than their non-white co-workers. The ethnic wage gap is 17 percent in the Northeast. It is measured at 15 percent in Pernambuco, 16 percent in Ceará; and 11 percent in Bahia. The analysis cannot reveal whether the wage disparate is due to discrimination or unmeasured skills, which are not included in the analysis. However, the findings should not be interpreted, as white workers are necessarily more productive than others.

${ }^{13}$ There are very few indigenous people covered by the survey in the Northeast. 
Figure 6

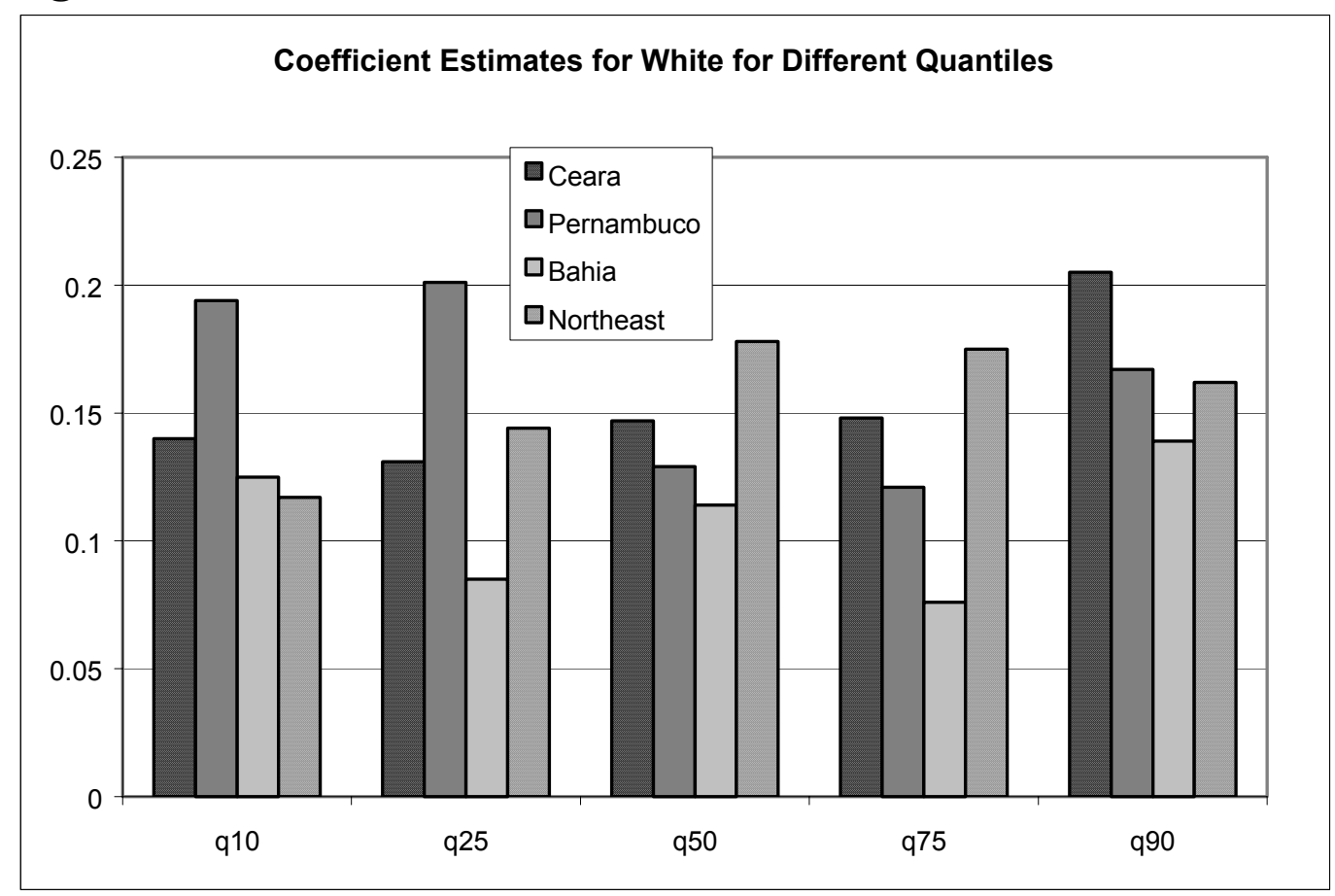

Data source: Author's calculation.

The data set used in this analysis did not include many relevant characteristics actually used by employers in their hiring and promotion choices. Nor is it idle speculation to conjecture that difference in family and schooling environments may account for any systematic variation in unmeasured characteristics between racial groups.

Is labor market discrimination by race a first-order problem in the Northeast and Brazil? Undoubtedly, there are employers and employees with discriminatory intentions in Brazil and in its states as well as in other countries. In most countries, the goal of achieving economic progress for racial minorities is better served by policies that promote skill formation, and not necessarily by strengthening the content and enforcement of civil rights laws.

Gender with regard to ethnicity. When the sample is divided in two sub-samplesone for males and one for females - there are no major differences to the above findings between the samples. The white workers are paid more and the premium to race is constant across the distribution in Northeast (tables C2 and C3). In Pernambuco, race plays a role in the wage determination process. In the female sample, returns are decreasing across the sample. Hence, in the low end of the distribution, white women are paid 28 percent more than non-whites while in the top; the wage gap is 15 percent. This contrasts the findings for the males where the wage disparity is fairly constant across the distribution (around 18 percent).

Gender. Are returns to gender homogeneous across the population living in a region and across regions? The regression findings show signs of large measurable inequalities between men and women and they suggest that the gender gap is 
heterogeneous across the quantiles but to a less extent heterogeneous across regions (table C1).

Female wages are statistically significantly different from male wages at all quantiles, and this holds for all three states and the Northeast region, adjusting for human capital and other worker characteristics. Furthermore, the gender gap is large (see figure 7). The Northeast sample reveals that women placed at the median (50 ${ }^{\text {th }}$ quantile) are paid around 29 percent less than their male colleagues. Additionally, the wage disparity increases with income group. For the $10^{\text {th }}$ quantile the gender gap is 29 percent. It increases to 36 and 34 percent for the $75^{\text {th }}$ and $90^{\text {th }}$ quantiles, respectively. The wage difference in Pernambuco and Bahia is pretty much in line with the rest of the Northeast. In Ceará, the gender wage differentials are larger than in the other Northeastern states. Furthermore, the wage differential between rich and poor is huge. For the rich the gender gap is almost double the size of the poor. Female workers in the $75^{\text {th }}$ and $90^{\text {th }}$ quantiles are paid 44 and 48 percent less, respectively, than their male peers.

\section{Figure 7}

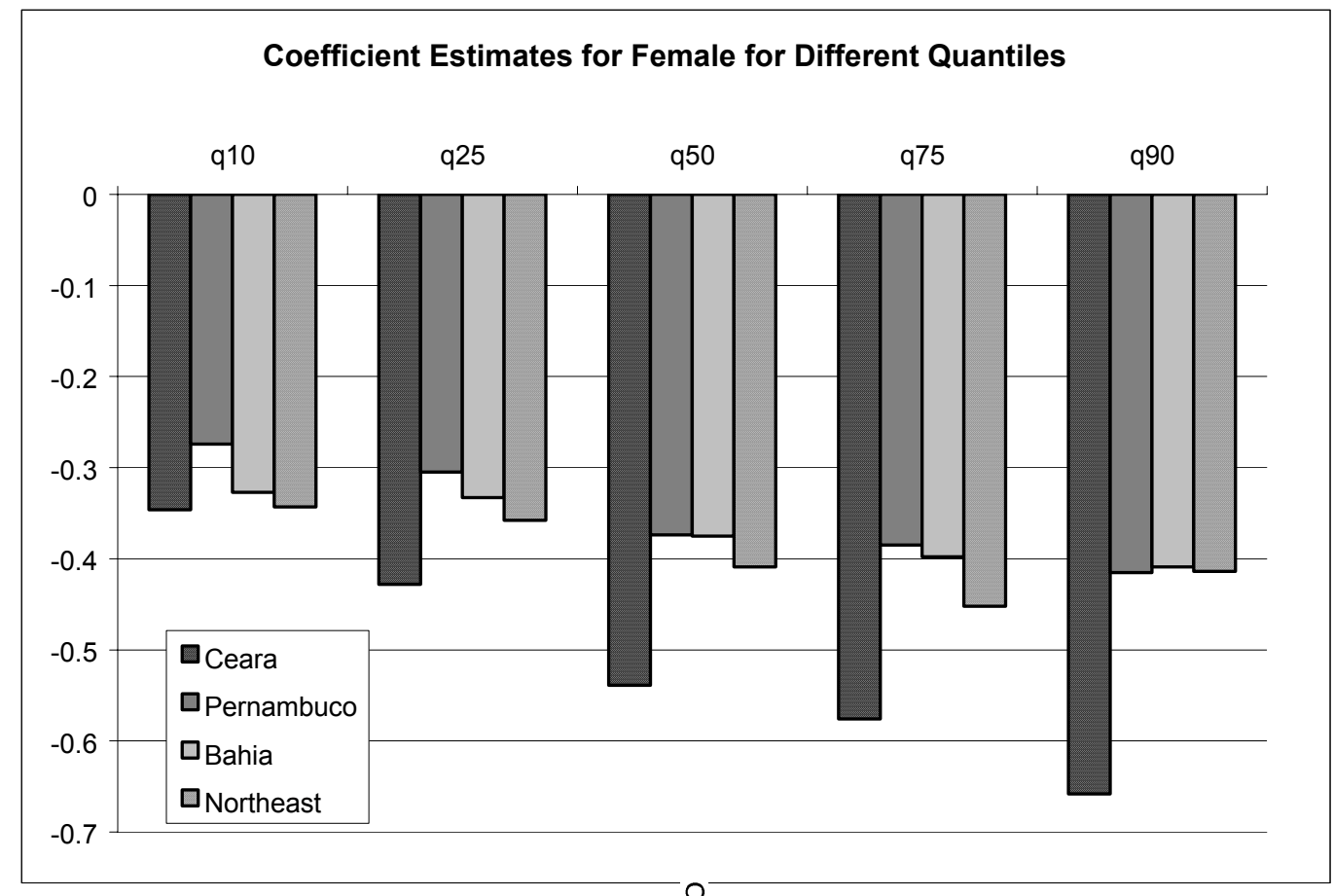

Data source: Author's calculation.

These findings, together with the findings presented in other sub-sections, suggest large differences in the wage determination process for men and women. The genderearning gap may to some degree be explained by choice of jobs chosen by women. Women are more likely than men to select jobs, which are more flexible in nature. For example, women may choose part time jobs or jobs with lower working hours than men as they wish to spend more time minding children and the like. A second factor that influences wages is that, the sector variables included in these regressions are very broad. For example, women employed in the service sector work as maids as well as bankers. 
This may influence the gender parameter estimates as relatively more women than men will be working in low skill jobs such as the former. A third explanation may be gender differences in unmeasured skills. The education levels are taken into account, but women's skill levels may be lower than men's. Hence, the data reveals that women are under capitalized not in terms of education, as they have more completed education than males (see table A1), but they may well be in terms of experience. Additionally, many women choose professions where they are less forced to capitalize, for example, they work more often in teaching than male peers. Hence, the data is not able to give a clearcut answer as to whether the wage disparity is due to pure discrimination in an economic sense or omitted information. It is very likely that including a larger set of very finely separated occupational variables would reduce the size of the estimated gender impacts.

\section{State, Metropolitan, Rural, and Urban living}

This subsection analyzes wage premia related to three variables on location and time lived in a state. The first variable, urban, quantifies the wage effect of living in urban versus rural areas. The second variable, metropol, measures the impact on wages of living in a metropolitan versus a non-metropolitan area. The third variable, liveten, determines the effect of having lived in the state for 10 years or more compared to having spent less than 10 years in the current state.

Urban areas exist because it is an advantage to pursue production and consumption activities in a spatially concentrated fashion. This, combined with the high population density, drives up prices of, for example, land. To compensate for higher prices the workers in urban areas require recompense. Findings show that in the Northeast and the three states, workers do receive compensation (table $\mathrm{C} 1$ ). Urban workers are paid statistically significantly more than workers in rural areas, when other characteristics are controlled for. These findings show that there are asymmetries in some areas of Brazil, and urban living delinks wages for some quantiles in, for example, Pernambuco.

The urban-rural wage gap for the Northeast is significantly different from zero for three quantiles (the $25^{\text {th }}, 50^{\text {th }}$ and $90^{\text {th }}$ ) and declining across the wage distribution, controlling for other covariates. In the Northeast, the urban premium is seven percent for the median worker. In the individual states, the urban variable is not statistically significantly different from zero. This is probably due to a combination of factors. First, a low number of observations are available for the three individual states, and, secondly, a metropolitan variable is included in the regressions. The expected higher wages in the urban area may, therefore, be captured by the metropolitan variable.

Workers living in the metropolitan areas in the Northeast, Bahia, Ceará, and Pernambuco are compensated in the form of a significant and positive wage premium at all quantiles. Hence, metropolitan living is more important in the wage determination than living in an urban area. The metropolitan variable estimates reveal that the wage premium differs across the wage distribution and samples. The median worker receives a 38 percent premium in the Northeast. This finding is constant across the distribution. In Pernambuco, Ceará, and Bahia, the compensation is 40, 47, and 44 percent, respectively, and heavily decreasing across the wage distribution. The difference in wages, which can be attributed to location, may capture more, for example, unmeasured skills than the difference in the cost of living in the urban and rural areas. 
Gender differences related to Metropolitan living. Splitting up the sample into two sub-groups, one for male and one for female, reveals that gender impacts the wage determination process also with regarding to habitation. Females in metropolitan areas obtain a substantial higher wage premium, almost the double, than their male co-workers in metropolitan areas. This is the case for all samples. The habitation contributes 51, 46, 56, and 65 percent for the median female in the Northeast, Pernambuco, Bahia and Ceará, respectively, while males obtain $28,33,29$, and 36 percent, respectively.

The time spent in the current state proves statistically significant in the wage determination process for the Northeast as a whole, Pernambuco and Ceará. Having spent more than 10 years in the same state impacts adversely on wages. That is, those that have stayed earn, on average, less than the newcomers. For a median worker in the Northeast, the impact of having lived more than 10 years in a state implies a 9 percent decrease in the wage. Furthermore, the magnitude is not constant across samples. For Pernambuco and Ceará, the time-in-state wage gap is larger; namely 17 and 20 percent, respectively, for the $90^{\text {th }}$ quantile. For Bahia, the time spent in the state has no influence on the wage obtained, except for the $50^{\text {th }}$ quantile where the time spent in the state is marginally significant and negative ( 8 percent). There are no considerable differences between male and female workers (tables $\mathrm{C} 2$ and $\mathrm{C} 3$ ). This negative gap is rather puzzling. One explanation may be that many educated and skilled workers left the region to move to the South expecting a higher wage premium and higher returns to their skills, leaving behind, as a consequence, their less-skilled and less-educated peers in, for example, Pernambuco. The newcomers to the Northeastern states may, therefore, on average be more skilled (of a kind not included in the analysis) and that could explain the wage difference. Also, the return of Nordestinos who moved to the South and obtained new skills that now return to the region could be another explanatory factor. Further analysis is needed to uncover the whole migration story behind the above findings.

\section{Union membership}

Union membership has an important impact on workers' wages. Trade union membership appears statistically significant and positive in all four samples, even when all the above-mentioned factors are taken into account.

For the Northeast as a whole, a union member in the low end of the wage distribution obtains a higher premium than a worker at the top. A worker placed in the $10^{\text {th }}$ and $90^{\text {th }}$ quantiles receives a 24 and 17 percent premium, respectively. Hence, returns are not constant but rather falling across the wage distribution.

In Pernambuco, union members are benefiting relative to non-union members in the wage process (except in the $90^{\text {th }}$ quantile, where union membership impact wages insignificantly). The return to union membership is around 18 percent and constant across the distribution. For Ceará and Bahia, the union wage gap is declining across the distribution and the median worker obtains 22 and 3 percent premia, respectively.

These findings are very much in line with the premium that European labor markets pay union members. For the poorest region in Brazil, these results are surprising due to high levels of underemployment and unemployment. The findings are different from other studies on developing countries and unions where the wage differential between 
members and non-union members often are negative, for example, in Africa or insignificant as in Mexico. ${ }^{14}$

In the theoretical literature on unions, it has long been recognized that unions may influence factors other than wages, such as security in employment (tenure).

Hence, union members are favored in terms of wages by the unions, given measured characteristics. It could be due to more successful bargaining over firm rents by this group of workers or insider power. Another explanation could be missing nonobservable characteristics in the analysis; for example, union members could have an exceptionally high motivation and are reliable or have unmeasured skills, which are captured by the union variable. If the union wage gap is indeed truly caused by unions, it may indicate lack of social awareness among the union members since this will secure neither the Pernambucan nor other Northeast states' competitiveness and their own future employment in a world of rapid technological change.

Gender differences related to union membership. Estimating the wage determination process for each gender separately shows no consistent difference between male and female workers.

\section{Conclusion}

The mean and quantile wage regression analyses for Pernambuco, Bahia, Ceará and the Northeast region as a whole for 1997 show a rather heterogeneous impact pattern of individual characteristics on monthly wages. This is also the case across the wage distribution, that is, the magnitude of the affect of a wage determinant is different depending on the worker being rich, poor or placed in the median of the wage distribution. In the following each of the wage determinants are discussed in turn.

Basic schooling matters for all four geographical areas and across the income distribution. However, poor workers are awarded lower returns than their rich peers. A striking finding shows that in Bahia and Ceará, the poor do not obtain any returns to basic schooling. Completed second part of primary school impacts wages significantly in the Northeast. The returns are larger in Pernambuco than elsewhere, and the poor are compensated similarly to the rich. Furthermore, the impact of 5-8 years of education is larger than of 1-4 years of completed education. Also, completed secondary education affects significantly wages in all samples. The returns obtained by a median worker are higher in Ceará and Pernambuco than in Bahia. In Ceará the returns are rapidly increasing across the distribution, and the poor people receive a 35 percent return and the rich a much higher, namely 93 percent return to completed secondary education. The same is true in Bahia. In Pernambuco, there is less variation across the distribution. Finally, completed tertiary education offers the largest returns of all levels of education;

14 See Maloney and Ribeiro (1999) on Mexico and Rama (1998), Verner (1999a), and Kristensen and Verner (2000) on Africa. 
the median worker receives a premium of 105, 249, and 216 percent in Ceará, Pernambuco, and Bahia, respectively.

Explanations for the lower returns that the poor obtain may relate to quality of supplied education and lack of social capital. Labor market capital is more abundant for richer workers. It is easier to obtain a "good" job when richer, since richer workers generally socialize with people that have connections, information and power. Hence, poor people do not have the same access to well paid jobs as rich people. The findings reveal that Pernambuco pays higher returns than Bahia for all levels of education and Ceará and Pernambuco alternate for different quantiles and levels of education. Hence, one direct policy implication is to increase the quality of education, in particular, in poorer neighborhoods. Additionally, launching of mentoring programs where wellheeled workers help less well off peers could aid and reduce the labor market capital disparities. These findings indicate that education tends to reduce the risk of poverty. The less education you have, the more likely it is that you move into poverty (also see Verner 2000).

General experience impacts positively on wages and it is increasing with age until workers reach 50 years of age. Returns to experience are falling significantly across the wage distribution. Hence, the poor experience a larger wage gap than richer workers. For the poor and younger generations, experience contributes more to wages than education. However, for workers in high end of the wage distribution, the educational impact is by far larger than the experience impact. Job-specific experience or tenure affects wages positively and returns are monotonically increasing with experience.

Labor market association is measured by the formality of one's job status. For Pernambuco and Bahia, a median worker with a signed working card obtains a 34 percent higher wage premium than a non-signed working cardholder and the premium declines across the wage distribution. That is, low-wage earners benefit more in term of wages from formal sector employment than high wage earners. Higher-quality jobs may require more skills; hence the signed workbook factor may partly capture unmeasured skills. The wage gap may also be caused by lower productivity in the informal sector compared to the formal sector, which is not picked up by education and other human capital or job specific information. Hence, workers in the informal sector are disadvantaged in at least two ways: first, they are less protected and second, they obtain lower wages, which evidently does not compensate informal workers for the absence of the protection which goes along formal sector work.

Sector of employment of a worker is included in the analysis and the agricultural sector is compared to industry and services and no measurable differences are revealed. The occupation of workers is important for wage determination; all workers in the included occupational groups are paid more than workers engaged in agricultural activities. Workers employed as technicians or administrators obtain the highest returns. Furthermore, the wage gap is constant across the distribution for all occupational groups.

The white/non-white wage disparity is significant for both the poor and rich workers. White workers are paid 17 percent more than their non-white co-workers, taking into account human capital, etc. 
Gender disparities are large in the Northeast and heterogeneous across the quantiles. For the poor the gender gap is 29 percent and it increases to 34 percent for the rich. In Ceará, the gender wage differentials are larger than in the other Northeastern states. Furthermore, the income of male workers increases more rapidly than income of females with the level of completed education and experience. Moreover, the returns to experience, in general as well as on-the-job, are higher for males than for females.

Urban area workers are compensated at higher prices. The urban-rural wage gap for the Northeast is 7 percent for the median worker and declining across the distribution. Workers living in the metropolitan areas are compensated in the form of a positive wage premium at all quantiles and metropolitan living is more important in the wage determination than living in an urban area.

The time spent in the current state impacts adversely on wages. That is, those that have stayed earn, on average, less than the newcomers. There are no considerable differences between male and female workers.

Union membership has an important impact on workers' wages. For the Northeast as a whole, a union member in the low end of the wage distribution obtains a higher premium than a peer at the top. A worker placed in the $10^{\text {th }}$ and $90^{\text {th }}$ quantiles receives a 24 and 17 percent premium, respectively.

The analysis shows that education has an important effect on wages and, therefore, on well being in the Northeast and the three states. The findings show the importance of improving the quality of obtained education, in particular, that of primary education. It is important to reduce dropout rates, so that more children continue and complete their secondary education. One direct action plan for the government would be to work with the private sector in order to expand the Bolsa de Escola program to the entire region and, furthermore, supply education credits so more children can complete secondary education.

One observation, which appears from this study, is a lack of skills. The reason may be that, in general, investing in training is risky for a firm, since the return is unclear, as the human capital obtained is not fixed in the firm. The trained workers own their brains, and can leave with the human capital and work in another firm. High labor turnover (47 percent) in Brazil increases this risk (see Gonzaga (1996)), resulting in too little investment in training by firms. The state can assist in the process of moving from a lowtraining equilibrium to a higher equilibrium with better jobs and more skills. Policy makers can facilitate the access to training for workers--both with and without a working card, in collaboration with the private sector. This would also increase the competitiveness of the workers when they have to compete with workers in other states and countries. In a world of increased globalization, job-saving technologies are widely being applied. 


\section{References}

Arias, O., K.F. Hollack, and W. Sosa (1999). "Individual Heterogeneity in the Returns to Schooling: Instrumental Variables Quantile Regression Using Twins Data,” Mimeo, university of Illinois

Barro, R.J. (1991) "Economic Growth in a Cross Section of Countries", Quarterly Journal of Economics, Vol. 106, No. 2.

Barros Paes de, R., S. Firpo, P. Leite, M. Bahia, and R. Barrete (1999) "Identificado do padres espaciais do processo de criação, destruição e realocação do emprego no Brasil" IPEA.

Barros R. and R. Mendonça (1997) "A Educação e o Processo de Determinação dos Salários no Nordeste Brasileiro", IPEA.

Buchinsky, M. (1998). "Recent Advances in Quantile Regression Models - A Practical Guideline for Empirical Research", The Journal of Human Resources, Vol. XXXIII, No. 1, pp. 88-126.

Card, D. (1998) "The Causal Effect of Education on Earnings", forthcoming in Handbook of Labor Economics, Vol. 3, Ashenfelter, O. and Card, D. (eds.)

Deaton, A. (1997) "The Analysis of household Surveys - A Microeconometric Approach to Development Policy", Johns Hopkins University Press, Baltimore.

Ferreira, F. and R. Paes de Barros (1999)

Gonzaga, M. G. (1996) “The Effect of Openness on Industrial Employment in Brazil” IPEA, Serie Seminarios No 27/96.

Juhn, C., K.M. Murphy, and Pierce, B. (1993) "Wage Inequality and the Rise in Returns to Skills", Journal of Political Economy, Vol. 101, No. 3.

Koenker, R. and Basset, G. Jr. (1978) "Regression Quantiles”, Econometrica, Vol. 46, No. 1, pp. 33-50.

Koenker and D’Orey (1993) “Computing Regression Quantiles”, Applied Statistics, 36, pp. 383-393, and 43, pp. 410-414.

Koenker, R. and Portnoy (1997) “Quantile Regression”, Office of Research Working Paper, No. 97-0100, College of Commerce and Business Administration, University of Illinois at Urbana-Champaign.

Kristensen, N. and D. Verner, (2000) "Labor Market Distortions in Côte d'Ivoire: A Quantile Regression Analysis on Employer-Employee Data", Mimeo, The World Bank, Washington, DC.

Levey, F. and R. J. Murnane, (1992) "U.S. Earnings Levels and Earnings Inequality: A Review of Recent Trends and Proposed Explanations", Journal of Economic Literature, Vol. 30, pp. 1333-1381. 
Maloney, W. F. and Ribeiro, E.P. (1999) "Efficiency Wage and Union Effects in Labor Demand and Wage Structure in Mexico: An Application of Quantile Analysis", Working Paper, The World Bank.

Mankiw, N.G., Romer, D., and Weil, D.N. (1992) "A Contribution to the Empirics of Economic Growth, Quarterly Journal of Economics, Vol. 107, No. 2."

Mincer, J. (1974) "Schooling, Experience and Earnings", NBER Working Paper, New York.

Oliveira C. W. de Albuquerque and L. Guimarães Neto (1999) "Emprego Organizado e Regiões Nos Anos 90: Quem Perdeu Mais?” Memio.

Rama, M. (1998). "Wage Misalignment in CFA Countries: Are Labor Market Policies to Blame?”, Policy Research Working Paper, No. 1873, The World Bank,

Washington DC.

Verner, D. (1999a) "Are Wages and productivity in Zimbabwe Affected by Human Capital Investment and International trade?", Policy Research Working Paper, No. 2101, The World Bank, Washington, DC.

Verner (1999b) "The Macro Wage-curve in Zimbabwe", Policy Research Working Paper, No. 2052, The World Bank, Washington, DC.

Verner, D. (1999c) "Wage and Productivity Gaps: Evidence from Ghana", Policy Research Working Paper, No. 2168, The World Bank, Washington, DC.

Verner, D. (2000) "The Dynamics of Poverty and its Determinants: The Case of Pernambuco and the Northeast Brazil" 


\title{
Appendixes
}

\author{
Wage determination in \\ Pernambuco, Bahia, Ceará amd the Northeast: \\ An Application of Quantile Regression
}

\begin{abstract}
Appendix A: Summary Statistics
Appendix B: Definition of Variables

Appendix C: Quantile Regression Findings

Appendix D: R? for Quantile Regression and OLS Regressions

Appendix F: ?
\end{abstract}


Appendix A. TABLE A1-BRAZIL. BASIC DESCRIPTIVE STATISTICS

\begin{tabular}{|c|c|c|c|c|c|c|c|c|c|c|c|c|c|c|}
\hline \multirow[t]{2}{*}{ variable } & \multicolumn{2}{|c|}{ all } & \multicolumn{2}{|c|}{ union } & \multicolumn{2}{|c|}{ nonunion } & \multicolumn{2}{|c|}{ males } & \multicolumn{2}{|c|}{ females } & \multicolumn{2}{|c|}{ white } & \multicolumn{2}{|c|}{ non-white } \\
\hline & freq & perc & freq & perc & freq & perc & freq & perc & freq & perc & freq & perc & freq & perc \\
\hline All & 106,282 & 100.0 & 18,024 & 100.0 & 88,258 & 100.0 & 62,574 & 100.0 & 43,708 & 100.0 & 56,971 & 100.0 & 49,311 & 100.0 \\
\hline male & 62,574 & 58.9 & 11,300 & 62.7 & 51,274 & 58.1 & na & na & na & na & 32,711 & 57.4 & 29,863 & 60.6 \\
\hline female & 43,708 & 41.1 & 6,724 & 37.3 & 36,984 & 41.9 & na & na & na & na & 24,260 & 42.6 & 19,448 & 39.4 \\
\hline white & 56,971 & 53.6 & 11,141 & 61.8 & 45,830 & 51.9 & 32,711 & 52.3 & 24.260 & 55.5 & na & na & na & na \\
\hline non-white & 49,311 & 46.4 & 6,883 & 38.2 & 42,428 & 48.1 & 29,863 & 47.7 & 19,448 & 44.5 & na & na & na & na \\
\hline non union & 88,258 & 83.0 & na & na & na & na & 51,274 & 81.9 & 36,984 & 84.6 & 45,830 & 80.4 & 42,428 & 86.0 \\
\hline age10_20 & 15,433 & 14.5 & 760 & 4.2 & 14,673 & 16.6 & 9,626 & 15.4 & 5,807 & 13.3 & 7,260 & 12.7 & 8,173 & 16.6 \\
\hline age21_30 & 30,885 & 29.1 & 4,462 & 24.8 & 26,423 & 29.9 & 17,974 & 28.7 & 12,911 & 29.5 & 16,181 & 28.4 & 14,704 & 29.8 \\
\hline age31_40 & 28,613 & 26.9 & 5,923 & 32.9 & 22,690 & 25.7 & 15,891 & 25.4 & 12,722 & 29.1 & 15,988 & 28.1 & 12,625 & 25.6 \\
\hline age41-50 & 19,308 & 18.2 & 4,297 & 23.8 & 15,011 & 17.0 & 11,012 & 17.6 & 8,296 & 19.0 & 10,887 & 19.1 & 8,421 & 17.1 \\
\hline age 51_70 & 12,043 & 11.3 & 2,582 & 14.3 & 9,460 & 10.7 & 8,071 & 12.9 & 3,972 & 9.1 & 6,655 & 11.7 & 5,388 & 10.9 \\
\hline stud0 & 10,886 & 10.2 & 1,307 & 7.3 & 9,579 & 10.9 & 7,555 & 12.1 & 3,331 & 7.6 & 3,292 & 5.8 & 7,594 & 15.4 \\
\hline stud5-8 & 29,886 & 28.1 & 3,907 & 21.7 & 25,979 & 29.4 & 18,194 & 29.1 & 11,692 & 26.8 & 15,891 & 27.9 & 13,995 & 28.4 \\
\hline stud9_11 & 23,772 & 22.4 & 4,961 & 27.5 & 18,811 & 21.3 & 11,927 & 19.1 & 11,845 & 27.1 & 14,452 & 25.4 & 9,320 & 18.9 \\
\hline stud12 $\mathrm{pl}$ & 12,420 & 11.7 & 4,672 & 25.9 & 7,748 & 8.8 & 5,813 & 9.3 & 6,607 & 15.1 & 9,845 & 17.3 & 2,575 & 5.2 \\
\hline primary sector & 12,433 & 12.0 & 2,111 & 12.3 & 10,322 & 11.9 & 10,943 & 17.9 & 1,490 & 3.5 & 5,214 & 9.4 & 7,219 & 14.9 \\
\hline second. sector & 22,831 & 22.0 & 4,148 & 24.2 & 18,683 & 21.5 & 18,137 & 29.7 & 4,694 & 11.0 & 12,281 & 22.2 & 10,550 & 21.7 \\
\hline tertiary sector & 68,585 & 66.0 & 10,854 & 63.4 & 57,731 & 66.6 & 32,007 & 52.4 & 36,578 & 85.5 & 37,786 & 68.4 & 30,799 & 63.4 \\
\hline married & 81,762 & 76.9 & 14,305 & 79.4 & 67,457 & 76.4 & 51,004 & 81.5 & 30,758 & 70.4 & 44,692 & 78.5 & 37,070 & 75.2 \\
\hline not married & 24,520 & 23.1 & 3,719 & 20.6 & 20,801 & 23.6 & 11,570 & 18.5 & 12,950 & 29.6 & 12,279 & 21.5 & 12,241 & 24.8 \\
\hline tenure 0 & 14,754 & 13.9 & 973 & 5.4 & 13,781 & 15.6 & 8,492 & 13.6 & 6,262 & 14.3 & 6,845 & 12.0 & 7,909 & 16.0 \\
\hline tenure 12 & 32,076 & 30.2 & 3,702 & 20.5 & 28,374 & 32.2 & 18,252 & 29.2 & 13,824 & 31.6 & 16,923 & 29.7 & 15,153 & 30.7 \\
\hline tenure 36 & 25,442 & 23.9 & 4,254 & 23.6 & 21,188 & 24.0 & 14,754 & 23.6 & 10,688 & 24.5 & 14,092 & 24.7 & 11,350 & 23.0 \\
\hline tenure $7-12$ & 16,207 & 15.3 & 3,803 & 21.1 & 12,404 & 14.1 & 9,573 & 15.3 & 6,634 & 15.2 & 9,076 & 15.9 & 7,131 & 14.5 \\
\hline tenure $13 \mathrm{pl}$ & 17,803 & 16.8 & 5,292 & 29.4 & 12,511 & 14.2 & 11,503 & 18.4 & 6,300 & 14.4 & 10,035 & 17.6 & 7,768 & 15.8 \\
\hline
\end{tabular}


Appendix A. TABLE A1-NORTH-EAST. BASIC DESCRIPTIVE STATISTICS

\begin{tabular}{|c|c|c|c|c|c|c|c|c|c|c|c|c|c|c|}
\hline \multirow[t]{2}{*}{ variable } & \multicolumn{2}{|c|}{ all } & \multicolumn{2}{|c|}{ union } & \multicolumn{2}{|c|}{ nonunion } & \multicolumn{2}{|c|}{ males } & \multicolumn{2}{|c|}{ females } & \multicolumn{2}{|c|}{ white } & \multicolumn{2}{|c|}{ non-white } \\
\hline & freq & perc & freq & perc & freq & perc & freq & perc & freq & perc & freq & perc & freq & perc \\
\hline All & 8,802 & 100.0 & 1,417 & 100.0 & 7,385 & 100.0 & 5,242 & 100.0 & 3,560 & 100.0 & 3,865 & 100.0 & 4,937 & 100.0 \\
\hline male & 5,242 & 59.6 & 955 & 67.4 & 4,287 & 58.1 & na & na & na & na & 2,257 & 58.4 & 2,985 & 60.5 \\
\hline female & 3,560 & 40.4 & 462 & 32.6 & 3,098 & 41.9 & na & na & na & na & 1,608 & 41.6 & 1,952 & 39.5 \\
\hline white & 3,865 & 43.9 & 693 & 48.9 & 3,172 & 42.9 & 2,257 & 43.1 & 1,952 & 54.8 & na & na & na & na \\
\hline non-white & 4,937 & 56.1 & 724 & 51.1 & 4,213 & 57.1 & 2,985 & 56.9 & 1,608 & 45.2 & na & na & na & na \\
\hline union & 1,417 & 16.1 & na & na & na & na & 955 & 18.2 & 462 & 13.0 & 693 & 17.9 & 724 & 14.7 \\
\hline non union & 7,385 & 83.9 & na & na & na & na & 4,287 & 81.8 & 3,098 & 87.0 & 3,172 & 82.1 & 4,213 & 85.3 \\
\hline age10_20 & 741 & 8.4 & 31 & 2.2 & 710 & 9.6 & 427 & 8.2 & 314 & 8.8 & 264 & 6.8 & 477 & 9.7 \\
\hline age21_30 & 2,253 & 25.6 & 301 & 21.2 & 1,952 & 26.4 & 1,331 & 25.4 & 922 & 25.9 & 983 & 25.4 & 1,270 & 25.7 \\
\hline age31_40 & 2,430 & 27.6 & 428 & 30.2 & 2,002 & 27.1 & 1,333 & 25.4 & 1,097 & 30.8 & 1,100 & 28.5 & 1,330 & 26.9 \\
\hline age41_50 & 1,933 & 22.0 & 393 & 27.7 & 1,540 & 20.9 & 1,143 & 21.8 & 790 & 22.2 & 873 & 22.6 & 1,060 & 21.5 \\
\hline age51_70 & 1,445 & 16.4 & 264 & 18.6 & 1,181 & 16.0 & 1,008 & 19.2 & 437 & 12.3 & 645 & 16.7 & 800 & 16.2 \\
\hline stud5_8 & 2,362 & 26.8 & 331 & 23.4 & 2,031 & 27.5 & 1,346 & 25.7 & 1,016 & 28.5 & 1,081 & 28.0 & 1,281 & 26.0 \\
\hline stud9_11 & 1,489 & 16.9 & 327 & 23.1 & 1,162 & 15.7 & 758 & 14.5 & 731 & 20.5 & 760 & 19.7 & 729 & 14.8 \\
\hline stud12-pl & 702 & 8.0 & 282 & 19.9 & 4,201 & 5.7 & 354 & 6.8 & 348 & 9.8 & 445 & 11.5 & 257 & 5.2 \\
\hline primary sector & 713 & 8.3 & 132 & 9.7 & 581 & 8.0 & 631 & 12.3 & 82 & 2.3 & 180 & 4.8 & 533 & 11.0 \\
\hline second. sector & 2,000 & 23.2 & 344 & 25.3 & 1,656 & 22.8 & 1,668 & 32.5 & 332 & 9.5 & 843 & 22.4 & 1,157 & 23.8 \\
\hline tertiary sector & 5,921 & 68.6 & 884 & 65.0 & 5,037 & 69.3 & 2,834 & 55.2 & 3,087 & 88.2 & 2,747 & 72.9 & 3,174 & 65.3 \\
\hline married & 6,782 & 23.0 & 1,105 & 22.0 & 5,677 & 76.9 & 4,3 & 82.2 & 2,471 & 69.4 & 2,991 & 77.4 & 3,791 & 76.8 \\
\hline not married & 2,020 & 77.0 & 312 & 78.0 & 1,708 & 23.1 & $\begin{array}{c}11 \\
931\end{array}$ & 17.8 & 1,089 & 30.6 & 874 & 22.6 & 1,146 & 23.2 \\
\hline tenure0 & 1,160 & 13.2 & 68 & 4.8 & 1,092 & 14.8 & & 12.6 & 502 & 14.1 & 418 & 10.8 & 742 & 15.0 \\
\hline tenure1_2 & 2,662 & 30.2 & 309 & 21.8 & 2,353 & 31.9 & 658 & 28.4 & 1,172 & 32.9 & 1,169 & 30.3 & 1,493 & 30.2 \\
\hline tenure3_6 & 2,118 & 24.1 & 340 & 24.0 & 1,778 & 24.1 & 1,490 & 24.2 & 850 & 23.9 & 961 & 24.9 & 1,157 & 23.4 \\
\hline tenure7-12 & 1,411 & 16.0 & 302 & 21.3 & 1,109 & 15.0 & 1,268 & 16.8 & 528 & 14.8 & 666 & 17.2 & 745 & 15.1 \\
\hline tenure $1 \overline{3} \mathrm{pl}$ & 1,451 & 16.5 & 398 & 28.1 & 1,053 & 14.3 & $\begin{array}{l}883 \\
943\end{array}$ & 18.0 & 508 & 14.3 & 651 & 16.8 & 800 & 16.2 \\
\hline
\end{tabular}


Appendix A. TABLE A1-BAHIA. BASIC DESCRIPTIVE STATISTICS

\begin{tabular}{|c|c|c|c|c|c|c|c|c|c|c|c|c|c|c|}
\hline \multirow[t]{2}{*}{ variable } & \multicolumn{2}{|c|}{ all } & \multicolumn{2}{|c|}{ union } & \multicolumn{2}{|c|}{ nonunion } & \multicolumn{2}{|c|}{ males } & \multicolumn{2}{|c|}{ females } & \multicolumn{2}{|c|}{ white } & \multicolumn{2}{|c|}{ non-white } \\
\hline & freq & perc & freq & perc & freq & perc & freq & perc & freq & perc & freq & perc & freq & perc \\
\hline all & 1988 & 100.0 & 279 & 14.0 & 1709 & 86.0 & 1153 & 58.0 & 835 & 42.0 & 755 & 100 & 1233 & 100 \\
\hline male & 1153 & 58.0 & 187 & 67.0 & 966 & 56.5 & na & na & na & na & 440 & 58.3 & 713 & 57.8 \\
\hline female & 835 & 42.0 & 92 & 33.0 & 743 & 43.5 & na & na & na & na & 315 & 41.7 & 520 & 42.2 \\
\hline white & 755 & 38.0 & 121 & 43.4 & 634 & 37.1 & 440 & 38.2 & 315 & 37.7 & na & na & na & na \\
\hline non-white & 1233 & 62.0 & 158 & 56.6 & 1075 & 62.9 & 713 & 61.8 & 520 & 62.3 & na & na & na & na \\
\hline union & 279 & 14.0 & na & na & na & na & 187 & 16.2 & 92 & 11.0 & 121 & 16.0 & 158 & 12.8 \\
\hline non union & 1709 & 86.0 & na & na & na & na & 966 & 83.8 & 743 & 89.0 & 634 & 84.0 & 1075 & 87.2 \\
\hline age10_20 & 195 & 9.8 & 10 & 3.6 & 185 & 10.8 & 115 & 10.0 & 80 & 9.6 & 61 & 8.1 & 134 & 10.9 \\
\hline age21_30 & 534 & 26.9 & 70 & 25.1 & 464 & 27.2 & 304 & 26.4 & 230 & 27.5 & 200 & 26.5 & 334 & 27.1 \\
\hline age31_40 & 518 & 26.1 & 69 & 24.7 & 449 & 26.3 & 273 & 23.7 & 245 & 29.3 & 192 & 22.4 & 326 & 26.1 \\
\hline age41_50 & 413 & 20.8 & 86 & 30.8 & 327 & $19 . .1$ & 227 & 19.7 & 186 & 22.3 & 168 & 22.3 & 245 & 19.9 \\
\hline age 51_70 & 328 & 16.5 & 44 & 15.8 & 284 & 16.6 & 234 & 20.3 & 94 & 11.3 & 134 & 17.8 & 194 & 15.7 \\
\hline stud5_8 & 562 & 28.3 & 71 & 25.5 & 491 & 28.7 & 307 & 26.6 & 255 & 30.5 & 214 & 28.3 & 348 & 28.2 \\
\hline stud9_11 & 263 & 13.2 & 57 & 20.4 & 206 & 12.1 & 143 & 12.4 & 120 & 14.4 & 125 & 16.6 & 138 & 11.2 \\
\hline stud12 $\mathrm{pl}$ & 121 & 6.1 & 53 & 19.0 & 68 & 4.0 & 61 & 5.3 & 60 & 7.2 & 67 & 8.9 & 54 & 4.4 \\
\hline primary sector & 159 & 8.1 & 16 & 5.7 & 143 & 8.4 & 143 & 12.6 & 16 & 2.0 & 44 & 6.0 & 115 & 9.4 \\
\hline second. sector & 541 & 27.6 & 81 & 29.0 & 460 & 26.9 & 458 & 40.2 & 83 & 10.1 & 192 & 26.0 & 349 & 28.6 \\
\hline tertiary sector & 1259 & 64.3 & 173 & 62.0 & 1086 & 63.6 & 538 & 47.2 & 721 & 87.9 & 504 & 68.1 & 755 & 61.9 \\
\hline married & 1508 & 75.9 & 212 & 76.0 & 1296 & 75.8 & 930 & 80.7 & 578 & 69.2 & 577 & 76.4 & 931 & 75.5 \\
\hline not married & 480 & 24.1 & 67 & 24.0 & 413 & 24.2 & 223 & 19.3 & 257 & 30.8 & 178 & 23.6 & 302 & 24.5 \\
\hline tenure 0 & 292 & 14.7 & 13 & 4.7 & 279 & 16.3 & 150 & 13.0 & 142 & 17.0 & 85 & 11.3 & 207 & 16.8 \\
\hline tenure1_2 & 633 & 31.8 & 72 & 25.8 & 561 & 32.8 & 354 & 30.7 & 279 & 33.4 & 247 & 32.7 & 386 & 31.3 \\
\hline tenure3_6 & 481 & 24.2 & 66 & 23.7 & 415 & 24.3 & 287 & 24.9 & 194 & 23.2 & 177 & 23.4 & 304 & 24.7 \\
\hline tenure7_12 & 286 & 14.4 & 58 & 20.8 & 228 & 13.3 & 171 & 14.8 & 115 & 13.8 & 127 & 16.8 & 159 & 12.9 \\
\hline tenure $13 \mathrm{pl}$ & 296 & 14.9 & 70 & 25.1 & 226 & 13.2 & 191 & 16.6 & 105 & 12.6 & 119 & 15.8 & 177 & 14.4 \\
\hline
\end{tabular}


Appendix A. TABLE A1-PERNAMBUCO. BASIC DESCRIPTIVE STATISTICS

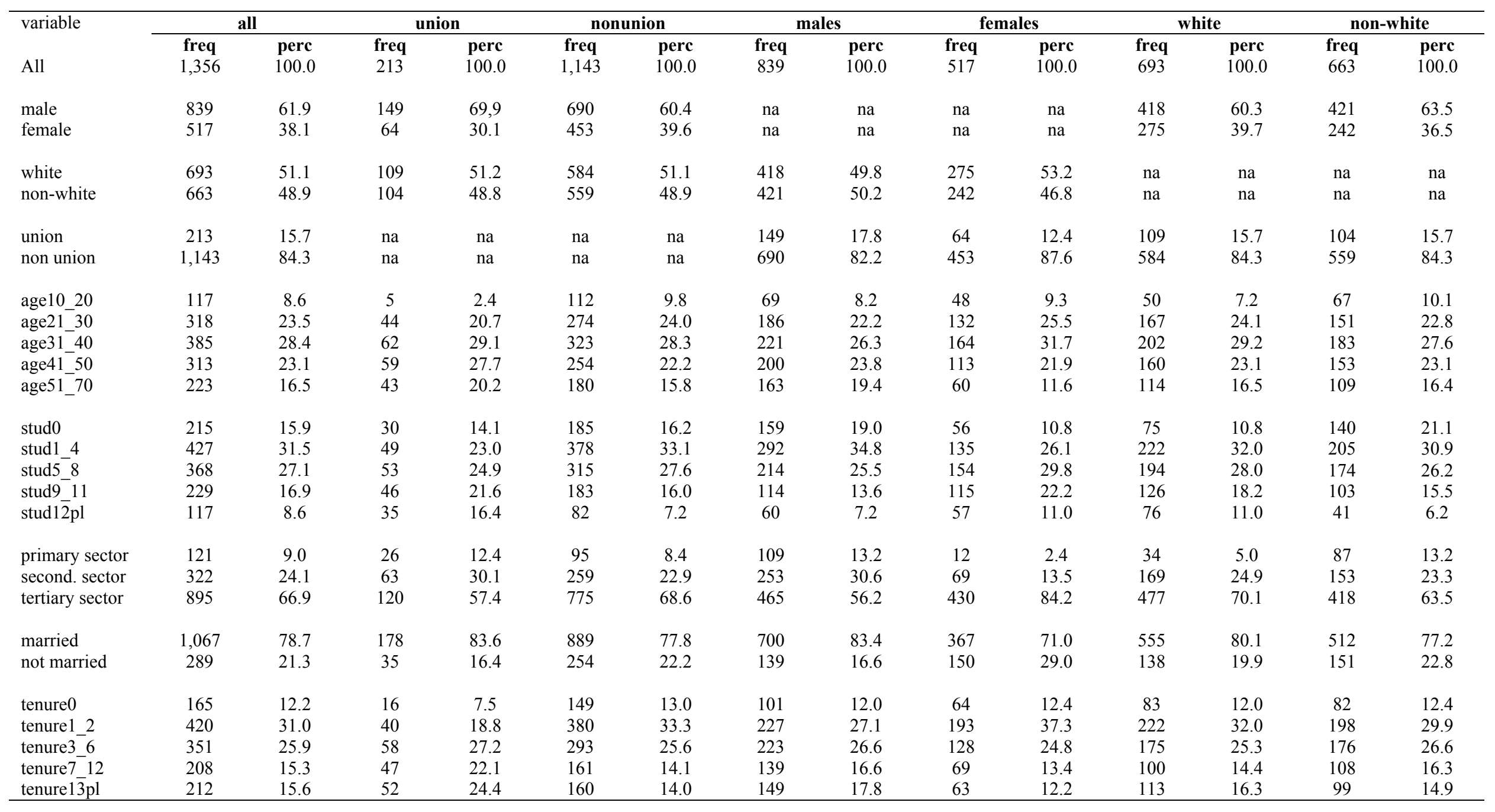




\section{Appendix A. TABLE A1-CEARA. BASIC DESCRIPTIVE STATISTICS}

\begin{tabular}{|c|c|c|c|c|c|c|c|c|c|c|c|c|c|c|}
\hline \multirow[t]{2}{*}{ variable } & \multicolumn{2}{|c|}{ all } & \multicolumn{2}{|c|}{ union } & \multicolumn{2}{|c|}{ nonunion } & \multicolumn{2}{|c|}{ males } & \multicolumn{2}{|c|}{ females } & \multicolumn{2}{|c|}{ white } & \multicolumn{2}{|c|}{ non-white } \\
\hline & freq & perc & freq & perc & freq & perc & freq & perc & freq & perc & freq & perc & freq & perc \\
\hline All & 1275 & 100.0 & 229 & 100.0 & 1046 & 100.0 & 802 & 100.0 & 473 & 100.0 & 652 & 100.0 & 623 & 100.0 \\
\hline male & 802 & 62.9 & 156 & 68.1 & 646 & 61.8 & na & na & na & na & 391 & 58.0 & 411 & 66.0 \\
\hline female & 473 & 37.1 & 73 & 31.9 & 400 & 38.2 & na & na & na & na & 261 & 40.0 & 212 & 34.0 \\
\hline white & 652 & 51.1 & 128 & 55.9 & 524 & 50.1 & 391 & 48.8 & 261 & 55.2 & na & na & na & na \\
\hline non-white & 623 & 48.9 & 101 & 44.1 & 522 & 49.9 & 411 & 51.2 & 212 & 44.8 & na & na & na & na \\
\hline non union & 1046 & 82.0 & na & na & na & na & 646 & 80.5 & 400 & 84.6 & 524 & 80.4 & 522 & 83.8 \\
\hline age10_20 & 95 & 7.5 & 0 & 0.0 & 95 & 9.1 & 55 & 6.9 & 40 & 8.5 & 36 & 5.5 & 59 & 9.5 \\
\hline age 2130 & 312 & 24.5 & 48 & 21.0 & 264 & 25.2 & 195 & 24.3 & 117 & 24.7 & 177 & 27.2 & 135 & 21.7 \\
\hline age $31-40$ & 337 & 26.4 & 64 & 28.0 & 273 & 26.1 & 196 & 24.4 & 141 & 29.8 & 172 & 26.4 & 165 & 26.5 \\
\hline age $41-50$ & 306 & 24.0 & 60 & 26.2 & 246 & 23.5 & 195 & 24.3 & 111 & 23.5 & 169 & 25.9 & 137 & 22.0 \\
\hline age 51_70 & 225 & 17.7 & 57 & 24.9 & 168 & 16.1 & 161 & 20.1 & 64 & 13.5 & 98 & 15.0 & 127 & 20.4 \\
\hline stud0 & 264 & 20.7 & 45 & 19.7 & 219 & 20.9 & 188 & 23.4 & 76 & 16.1 & 90 & 13.8 & 174 & 27.9 \\
\hline stud5_8 & 316 & 24.8 & 53 & 23.1 & 263 & 25.1 & 189 & 23.6 & 127 & 26.9 & 182 & 27.9 & 134 & 21.5 \\
\hline stud9_11 & 184 & 14.4 & 34 & 14.9 & 150 & 14.3 & 95 & 11.9 & 89 & 18.8 & 120 & 18.4 & 64 & 10.3 \\
\hline stud12 $\mathrm{pl}$ & 111 & 8.7 & 47 & 20.5 & 64 & 6.1 & 70 & 8.7 & 41 & 8.7 & 84 & 12.7 & 27 & 4.3 \\
\hline primary sector & 114 & 9.1 & 32 & 14.6 & 82 & 8.0 & 97 & 12.5 & 17 & 3.6 & 22 & 3.5 & 92 & 15.0 \\
\hline second. sector & 288 & 23.1 & 53 & 24.2 & 235 & 22.9 & 237 & 30.4 & 51 & 10.9 & 140 & 22.2 & 148 & 24.1 \\
\hline tertiary sector & 845 & 67.8 & 134 & 61.2 & 711 & 69.2 & 445 & 57.1 & 400 & 85.5 & 470 & 74.4 & 375 & 61.0 \\
\hline married & 1024 & 80.3 & 183 & 79.9 & 841 & 80.4 & 673 & 83.9 & 351 & 74.2 & 523 & 80.2 & 501 & 80.4 \\
\hline not married & 251 & 16.7 & 46 & 20.1 & 205 & 19.6 & 129 & 16.1 & 122 & 25.8 & 129 & 19.8 & 122 & 19.6 \\
\hline tenure 0 & 138 & 10.8 & 9 & 3.9 & 129 & 12.3 & 83 & 10.4 & 55 & 11.6 & 49 & 7.5 & 89 & 14.3 \\
\hline tenure1_2 & 368 & 28.9 & 49 & 21.4 & 319 & 30.5 & 220 & 27.4 & 148 & 31.3 & 187 & 28.7 & 181 & 29.1 \\
\hline tenure3_6 & 311 & 24.4 & 50 & 21.8 & 261 & 25.0 & 188 & 23.4 & 123 & 26.0 & 168 & 25.8 & 143 & 23.0 \\
\hline tenure7_12 & 237 & 18.6 & 57 & 24.9 & 180 & 17.2 & 157 & 19.6 & 80 & 16.9 & 145 & 22.2 & 92 & 14.8 \\
\hline tenure $1 \overline{3} \mathrm{pl}$ & 221 & 17.3 & 64 & 28.0 & 157 & 15.0 & 154 & 19.2 & 67 & 14.2 & 103 & 15.8 & 118 & 18.9 \\
\hline
\end{tabular}


Appendix A. TABLE A2. MEAN AND STANDARD DEVIATIONS

\begin{tabular}{|c|c|c|c|c|c|c|c|c|c|c|}
\hline \multirow[t]{2}{*}{ variable } & \multicolumn{2}{|c|}{ Brazil } & \multicolumn{2}{|c|}{ North-East } & \multicolumn{2}{|c|}{ Bahia } & \multicolumn{2}{|c|}{ Pernambuco } & \multicolumn{2}{|c|}{ Ceara } \\
\hline & mean & std & mean & std & mean & std & mean & std & mean & std \\
\hline income & 523.87 & 1013.40 & 515.85 & 780.69 & 511.30 & 778.94 & 548.39 & 926.16 & 539.58 & 811.45 \\
\hline age & 34.12 & 12.45 & 37.22 & 12.61 & 36.72 & 12.90 & 37.63 & 12.69 & 38.03 & 12.51 \\
\hline tenure & 6.40 & 7.95 & 6.45 & 7.94 & 5.89 & 7.36 & 6.40 & 8.05 & 6.81 & 7.91 \\
\hline $\begin{array}{l}\text { years } \\
\text { studied }\end{array}$ & 6.76 & 4.38 & 5.64 & 4.34 & 5.25 & 4.06 & 5.77 & 4.35 & 5.37 & 4.46 \\
\hline
\end{tabular}

Appendix A. TABLE A3-BRAZIL. PERCENTILES AND RATIO'S OF PERCENTILES FOR MONTHLY WAGES

\begin{tabular}{|c|c|c|c|c|c|c|c|}
\hline $\begin{array}{l}\text { percentiles and } \\
\text { ratio's }\end{array}$ & all & union & non-union & males & females & white & non-white \\
\hline \multicolumn{8}{|l|}{ percentiles } \\
\hline 10 & 87.20 & 144.52 & 77.52 & 104.34 & 66.32 & 116.27 & 62.98 \\
\hline 50 & 265.28 & 497.39 & 232.55 & 309.49 & 221.06 & 339.13 & 193.79 \\
\hline 90 & 1105.31 & 1989.57 & 906.36 & 1326.38 & 884.25 & 1627.27 & 663.19 \\
\hline 99 & 4421.26 & 5747.63 & 3391.29 & 4644.70 & 3094.88 & 5526.57 & 2232.44 \\
\hline \multicolumn{8}{|l|}{ ratio's } \\
\hline $50 / 10$ & 3.04 & 3.44 & 3.00 & 2.97 & 3.33 & 2.92 & 3.08 \\
\hline $90 / 10$ & 12.67 & 13.77 & 11.69 & 12.71 & 13.33 & 14.00 & 10.53 \\
\hline $99 / 10$ & 50.70 & 39.77 & 43.75 & 46.43 & 46.67 & 47.53 & 35.45 \\
\hline $90 / 50$ & 4.17 & 4.00 & 3.90 & 4.29 & 4.00 & 4.80 & 3.42 \\
\hline $99 / 50$ & 16.67 & 11.56 & 14.58 & 15.65 & 14.00 & 16.30 & 11.52 \\
\hline $99 / 90$ & 4.00 & 2.89 & 3.74 & 3.65 & 3.50 & 3.40 & 3.37 \\
\hline
\end{tabular}


Appendix A. TABLE A3-NORTH-EAST. PERCENTILES AND RATIO'S OF PERCENTILES FOR MONTHLY WAGES

\begin{tabular}{|c|c|c|c|c|c|c|c|}
\hline $\begin{array}{l}\text { percentiles and } \\
\text { ratio's }\end{array}$ & all & union & non-union & males & females & white & non-white \\
\hline \multicolumn{8}{|l|}{ percentiles } \\
\hline 10 & 110.53 & 166.95 & 104.34 & 116.27 & 87.20 & 122.09 & 88.43 \\
\hline 50 & 309.49 & 552.66 & 276.33 & 377.68 & 231.67 & 386.86 & 265.28 \\
\hline 90 & 1105.31 & 1879.03 & 909.67 & 1162.73 & 872.05 & 1381.64 & 872.05 \\
\hline 99 & 3372.14 & 4973.91 & 2906.82 & 3853.88 & 2906.82 & 4421.26 & 2713.03 \\
\hline \multicolumn{8}{|l|}{ ratio's } \\
\hline $50 / 10$ & 2.80 & 3.31 & 2.65 & 3.25 & 2.66 & 3.17 & 3.00 \\
\hline $90 / 10$ & 10.00 & 11.26 & 8.72 & 10.00 & 10.00 & 11.32 & 9.86 \\
\hline $99 / 10$ & 30.51 & 29.79 & 27.86 & 33.15 & 33.33 & 36.21 & 30.68 \\
\hline $90 / 50$ & 3.57 & 3.40 & 3.29 & 3.08 & 3.76 & 3.57 & 3.29 \\
\hline $99 / 50$ & 10.90 & 9.00 & 10.52 & 10.20 & 12.55 & 11.43 & 10.23 \\
\hline $99 / 90$ & 3.05 & 2.65 & 3.20 & 3.31 & 3.33 & 3.20 & 3.11 \\
\hline
\end{tabular}

\section{Appendix A. TABLE A3_BAHIA. PERCENTILES AND RATIO'S OF PERCENTILES FOR MONTHLY WAGES}

\begin{tabular}{|c|c|c|c|c|c|c|c|}
\hline $\begin{array}{l}\text { percentiles and } \\
\text { ratio's }\end{array}$ & all & union & non-union & males & females & white & non-white \\
\hline \multicolumn{8}{|l|}{ percentiles } \\
\hline 10 & 116.27 & 241.83 & 115.62 & 132.64 & 110.53 & 132.64 & 112.40 \\
\hline 50 & 331.59 & 552.66 & 309.49 & 387.22 & 267.49 & 385.39 & 309.49 \\
\hline 90 & 994.78 & 2210.63 & 884.25 & 1156.16 & 770.78 & 1453.41 & 823.60 \\
\hline 99 & 2763.28 & 5526.57 & 2210.63 & 3315.94 & 2763.29 & 3868.60 & 2210.63 \\
\hline \multicolumn{8}{|l|}{ ratio's } \\
\hline $50 / 10$ & 2.85 & 2.29 & 2.68 & 2.92 & 2.42 & 2.91 & 2.75 \\
\hline $90 / 10$ & 8.56 & 9.14 & 7.65 & 8.72 & 6.97 & 10.96 & 7.33 \\
\hline $99 / 10$ & 23.77 & 22.85 & 19.12 & 25.00 & 25.00 & 29.17 & 19.67 \\
\hline $90 / 50$ & 3.00 & 4.00 & 2.86 & 2.98 & 2.88 & 3.77 & 2.66 \\
\hline $99 / 50$ & 8.33 & 10.00 & 7.14 & 8.56 & 10.33 & 10.04 & 7.14 \\
\hline 99/90 & 2.78 & 2.50 & 2.50 & 2.87 & 3.59 & 2.66 & 2.68 \\
\hline
\end{tabular}


Appendix A. TABLE A3-PERNAMBUCO. PERCENTILES AND RATIO'S OF PERCENTILES FOR MONTHLY WAGES

\begin{tabular}{|c|c|c|c|c|c|c|c|}
\hline $\begin{array}{l}\text { percentiles and } \\
\text { ratio's }\end{array}$ & all & union & non-union & males & females & white & non-white \\
\hline \multicolumn{8}{|l|}{ percentiles } \\
\hline 10 & 115.62 & 174.41 & 115.62 & 116.27 & 110.53 & 132.64 & 96.35 \\
\hline 50 & 331.59 & 519.36 & 309.49 & 386.86 & 265.28 & 386.86 & 271.30 \\
\hline 90 & 1105.31 & 1453.41 & 968.94 & 1215.85 & 872.05 & 1252.51 & 884.25 \\
\hline 99 & 3853.88 & 3338.94 & 3853.88 & 3853.88 & 3372.14 & 4421.26 & 2713.03 \\
\hline \multicolumn{8}{|l|}{ ratio's } \\
\hline $50 / 10$ & 2.86 & 2.98 & 2.68 & 3.33 & 2.40 & 2.92 & 2.82 \\
\hline $90 / 10$ & 9.56 & 8.33 & 8.38 & 10.46 & 7.89 & 9.44 & 9.18 \\
\hline $99 / 10$ & 33.33 & 19.14 & 33.33 & 33.15 & 30.51 & 33.33 & 28.16 \\
\hline $90 / 50$ & 3.33 & 2.80 & 3.13 & 3.14 & 3.29 & 3.24 & 3.26 \\
\hline $99 / 50$ & 11.62 & 6.43 & 12.45 & 9.96 & 12.71 & 11.43 & 10.00 \\
\hline $99 / 90$ & 3.49 & 2.30 & 3.98 & 3.17 & 3.87 & 3.53 & 3.07 \\
\hline
\end{tabular}

Appendix A. TABLE A3-CEARA. PERCENTILES AND RATIO'S OF PERCENTILES FOR MONTHLY WAGES

\begin{tabular}{|c|c|c|c|c|c|c|c|}
\hline $\begin{array}{l}\text { percentiles and } \\
\text { ratio's }\end{array}$ & all & union & non-union & males & females & white & non-white \\
\hline \multicolumn{8}{|l|}{ percentiles } \\
\hline 10 & 96.35 & 116.27 & 96.35 & 116.27 & 58.43 & 123.65 & 58.43 \\
\hline 50 & 309.49 & 481.73 & 276.33 & 385.39 & 221.06 & 385.39 & 231.23 \\
\hline 90 & 1162.73 & 1926.94 & 968.94 & 1326.38 & 884.25 & 1657.97 & 674.38 \\
\hline 99 & 3853.88 & 7751.52 & 3315.94 & 4166.44 & 3391.29 & 4752.85 & 1937.88 \\
\hline \multicolumn{8}{|l|}{ ratio's } \\
\hline $50 / 10$ & 3.21 & 4.14 & 2.87 & 3.31 & 3.78 & 3.11 & 3.96 \\
\hline $90 / 10$ & 12.07 & 16.57 & 10.06 & 11.41 & 15.13 & 13.41 & 11.54 \\
\hline $99 / 10$ & 40.00 & 66.67 & 34.42 & 35.83 & 58.04 & 38.44 & 33.17 \\
\hline $90 / 50$ & 3.76 & 4.00 & 3.51 & 3.44 & 4.00 & 4.30 & 2.91 \\
\hline $99 / 50$ & 12.45 & 16.09 & 12.00 & 10.81 & 15.34 & 12.33 & 8.38 \\
\hline $99 / 90$ & 3.31 & 4.02 & 3.42 & 3.14 & 3.84 & 2.87 & 2.87 \\
\hline
\end{tabular}


Appendix A. TABLE A4. SOME MORE PERCENTILES AND RATIO'S OF PERCENTILES

\begin{tabular}{|c|c|c|c|c|c|c|c|}
\hline Brazil & stud0 & stud1_4 & stud5_8 & stud9_11 & stud12pl & rural & urban \\
\hline 10th & 99.478 & 97.268 & 83.474 & 77.372 & 77.515 & 46.954 & 106.583 \\
\hline 50th & 290.682 & 309.488 & 276.329 & 239.986 & 232.546 & 135.644 & 290.682 \\
\hline 90th & 1182.686 & 1326.377 & 1326.377 & 1105.314 & 775.152 & 449.590 & 1215.846 \\
\hline 99th & 4421.257 & 4650.911 & 4642.320 & 4421.257 & 2441.728 & 2086.838 & 4421.257 \\
\hline $50 / 10$ & 2.922 & 3.182 & 3.310 & 3.102 & 3.000 & 2.889 & 2.727 \\
\hline $90 / 10$ & 11.889 & 13.636 & 15.890 & 14.286 & 10.000 & 9.575 & 11.407 \\
\hline $99 / 10$ & 44.444 & 47.816 & 55.614 & 57.143 & 31.500 & 44.444 & 41.482 \\
\hline $90 / 50$ & 4.069 & 4.286 & 4.800 & 4.606 & 3.333 & 3.314 & 4.183 \\
\hline $99 / 50$ & 15.210 & 15.028 & 16.800 & 18.423 & 10.500 & 15.385 & 15.210 \\
\hline $99 / 90$ & 3.738 & 3.506 & 3.500 & 4.000 & 3.150 & 4.642 & 3.636 \\
\hline NE & stud0 & stud1_4 & stud5_8 & stud9_11 & stud12pl & rural & urban \\
\hline 10th & 116.273 & 115.616 & 96.894 & 96.894 & 104.342 & 43.394 & 116.273 \\
\hline 50th & 331.594 & 331.594 & 309.488 & 289.041 & 289.041 & 157.253 & 331.594 \\
\hline 90th & 1162.728 & 1259.622 & 1162.728 & 994.783 & 884.251 & 472.069 & 1105.314 \\
\hline 99th & 3853.879 & 3853.879 & 3853.879 & 3372.144 & 2210.629 & 2712.116 & 3391.289 \\
\hline $50 / 10$ & 2.852 & 2.868 & 3.194 & 2.983 & 2.770 & 3.624 & 2.852 \\
\hline $90 / 10$ & 10.000 & 10.895 & 12.000 & 10.267 & 8.475 & 10.879 & 9.506 \\
\hline $99 / 10$ & 33.145 & 33.333 & 39.774 & 34.802 & 21.186 & 62.500 & 29.167 \\
\hline $90 / 50$ & 3.506 & 3.799 & 3.757 & 3.442 & 3.059 & 3.002 & 3.333 \\
\hline $99 / 50$ & 11.622 & 11.622 & 12.452 & 11.667 & 7.648 & 17.247 & 10.227 \\
\hline $99 / 90$ & 3.315 & 3.060 & 3.315 & 3.390 & 2.500 & 5.745 & 3.068 \\
\hline Bahia & stud0 & stud1_4 & stud5_8 & stud9_11 & stud12pl & rural & urban \\
\hline 10th & 128.869 & 116.273 & 116.273 & 115.616 & 116.273 & 78.678 & 116.273 \\
\hline 50th & 339.783 & 337.214 & 331.594 & 331.594 & 331.594 & 195.272 & 337.214 \\
\hline 90th & 1105.314 & 1215.846 & 1105.314 & 934.566 & 884.251 & 505.788 & 1105.314 \\
\hline 99th & 2890.409 & 3315.943 & 3372.144 & 2809.925 & 2210.629 & 1123.974 & 2763.286 \\
\hline $50 / 10$ & 2.637 & 2.900 & 2.852 & 2.868 & 2.852 & 2.482 & 2.900 \\
\hline $90 / 10$ & 8.577 & 10.457 & 9.506 & 8.083 & 7.605 & 6.429 & 9.506 \\
\hline $99 / 10$ & 22.429 & 28.519 & 29.002 & 24.304 & 19.012 & 14.286 & 23.766 \\
\hline $90 / 50$ & 3.253 & 3.606 & 3.333 & 2.818 & 2.667 & 2.590 & 3.278 \\
\hline $99 / 50$ & 8.507 & 9.833 & 10.169 & 8.474 & 6.667 & 5.756 & 8.194 \\
\hline $99 / 90$ & 2.615 & 2.727 & 3.051 & 3.007 & 2.500 & 2.222 & 2.500 \\
\hline Pernambuco & stud0 & stud1_4 & stud5_8 & stud9_11 & stud12pl & rural & urban \\
\hline 10th & 125.210 & 116.273 & 110.531 & 110.531 & 114.776 & 57.315 & 116.273 \\
\hline 50th & 364.754 & 353.701 & 331.594 & 314.905 & 313.026 & 156.513 & 348.818 \\
\hline 90th & 1162.728 & 1326.377 & 1156.164 & 1105.314 & 884.251 & 460.830 & 1105.314 \\
\hline 99th & 4360.229 & 4421.257 & 4421.257 & 3853.879 & 2210.629 & 2820.601 & 4360.229 \\
\hline $50 / 10$ & 2.913 & 3.042 & 3.000 & 2.849 & 2.727 & 2.731 & 3.000 \\
\hline $90 / 10$ & 9.286 & 11.407 & 10.460 & 10.000 & 7.704 & 8.040 & 9.506 \\
\hline $99 / 10$ & 34.823 & 38.025 & 40.000 & 34.867 & 19.260 & 49.212 & 37.500 \\
\hline $90 / 50$ & 3.188 & 3.750 & 3.487 & 3.510 & 2.825 & 2.944 & 3.169 \\
\hline $99 / 50$ & 11.954 & 12.500 & 13.333 & 12.238 & 7.062 & 18.022 & 12.500 \\
\hline $99 / 90$ & 3.750 & 3.333 & 3.824 & 3.487 & 2.500 & 6.121 & 3.945 \\
\hline Ceara & stud0 & stud1_4 & stud5_8 & stud9_11 & stud12pl & rural & urban \\
\hline 10th & 116.273 & 88.425 & 81.387 & 83.474 & 84.916 & 26.085 & 116.273 \\
\hline 50th & 340.437 & 331.594 & 290.682 & 290.682 & 287.382 & 134.877 & 331.594 \\
\hline
\end{tabular}




\begin{tabular}{lrrrrrrr} 
90th & 1326.377 & 1326.377 & 1252.511 & 1059.817 & 884.251 & 521.709 & 1215.846 \\
99 th & 4166.440 & 4166.440 & 4421.257 & 3853.879 & 2422.349 & 2608.547 & 3853.879 \\
$50 / 10$ & 2.928 & 3.750 & 3.572 & 3.482 & 3.384 & 5.171 & 2.852 \\
$90 / 10$ & 11.407 & 15.000 & 15.390 & 12.696 & 10.413 & 20.000 & 10.457 \\
$99 / 10$ & 35.833 & 47.118 & 54.324 & 46.169 & 28.526 & 100.000 & 33.145 \\
$90 / 50$ & 3.896 & 4.000 & 4.309 & 3.646 & 3.077 & 3.868 & 3.667 \\
$99 / 50$ & 12.239 & 12.565 & 15.210 & 13.258 & 8.429 & 19.340 & 11.622 \\
$99 / 90$ & 3.141 & 3.141 & 3.530 & 3.636 & 2.739 & 5.000 & 3.170 \\
\hline
\end{tabular}


Appendix B. TABLE B1. DEFINITION OF VARIABLES 
lived in this state for 5-9 years, from v5063

lived in this state for at least ten years, from v5065

self-assessed read and write ability (not arith.), from v0601

highest level of education attended in the past, from v0607

yes/no to the previous question v0607, from v0608

worked in reference week yes/no? (incl. self-empl, from v9001)

metropolitan area or not, from v4727

urban rural dummy, from v4728

monthly income from primary/principle source, from v9532

union member yes/no?, from v9087

monthly income from additional source, from v9982

education level reached, from v470

years spend in school, from v4703

occupational category, from $v 470$

agriculture dummy, from v4708

occupational group

total individual income, from $\mathbf{v} 4720$

total household income, from $v 4721$

family characteristics/\#children, from v4723

yrs of school (yrs group

In(income)

tenure, calculated using v9611 and v9612

dummy $=1$ if tenure is less than 6 months

dummy $=1$ if tenure is $1-2$ years

dummy $=1$ if torure is $7-12$ years

dummy $=1$ if tenure is 13 years and plus

tenure squared

dummy $=1$ if age between 10-20 years

dummy $=1$ if age between $21-30$ years

dummy 1 if

dummy $=1$ if

age squared

white and zero otherwise

dummy $=1$ if zero years of study

dummy $=1$ if $5-8$ years of study

dummy $=1$ if $9-11$ years of study

dummy $=1$ if 12 or more (plus) years of study

dummy $=1$ if sector=agricultural, v 4709

dummy $=1$ if sector-manufacturing, v4709

dummy $=1$ if sector=other industry, $v 4709$

dummy 1 if sector=transport/communication or trade/commerce, v4709

dummy $=1$ if sector=service (incl. financial services), v4709

dummy $=1$ if sector=social, $v 4709$

dummy $=1$ if sector=public, $v 4709$

dummy $=1$ if sector=NA or other

dummy $=1$ if sector=primary sector (identical to agriculture (i.e.=agric))

dummy $=1$ if sector=secondary sector (identical to manufact+construct+otherin)

dummy $=1$ if sector= tertiary sector (id. to tracom+service+social+public)

dummy $=1$ if occupation=agriculture and agricultural products

dummy $=1$ if occupation=technician or administration

dummy $=1$ if occupation=transformation industry/ manufacturing

dummy $=1$ if occupation=transport/communication/commerce/trade

dummy $=1$ if occupation=seAtize dummy $=1$ if occupation=NA/other

dummy $=1$ if married and zero otherwise, from 4723

dummy $=1$ for child family and zero otherwise

dummy $=1$ if northern region and zero otherwise

dummy $=1$ if north-eastern region and zero otherwise 
Appendix C1. Quantile regressions including all individuals

\begin{tabular}{|c|c|c|c|c|c|c|c|c|c|c|}
\hline NE, all & $\begin{array}{l}\text { Coef. } \\
\text { Q10 }\end{array}$ & $P>|t|$ & $\begin{array}{c}\text { Coef. } \\
\text { q25 }\end{array}$ & $P>|t|$ & $\begin{array}{c}\text { Coef. } \\
\text { q50 }\end{array}$ & $P>|t|$ & $\begin{array}{c}\text { Coef. } \\
\text { q75 }\end{array}$ & $P>|t|$ & $\begin{array}{c}\text { Coef. } \\
\text { q90 }\end{array}$ & $P>|t|$ \\
\hline female & -0.343 & 0.000 & -0.358 & 0.000 & -0.409 & 0.000 & -0.452 & 0.000 & -0.414 & 0.000 \\
\hline white & 0.117 & 0.000 & 0.144 & 0.000 & 0.178 & 0.000 & 0.175 & 0.000 & 0.162 & 0.000 \\
\hline union & 0.214 & 0.000 & 0.175 & 0.000 & 0.144 & 0.000 & 0.132 & 0.000 & 0.154 & 0.001 \\
\hline urban & 0.100 & 0.166 & 0.087 & 0.066 & 0.064 & 0.063 & 0.058 & 0.192 & 0.067 & 0.079 \\
\hline metropol & 0.319 & 0.000 & 0.320 & 0.000 & 0.324 & 0.000 & 0.270 & 0.000 & 0.209 & 0.000 \\
\hline liveten & -0.111 & 0.004 & -0.096 & 0.000 & -0.091 & 0.000 & -0.112 & 0.000 & -0.077 & 0.014 \\
\hline age21_30 & 0.352 & 0.000 & 0.318 & 0.000 & 0.277 & 0.000 & 0.324 & 0.000 & 0.264 & 0.000 \\
\hline age31_40 & 0.468 & 0.000 & 0.433 & 0.000 & 0.480 & 0.000 & 0.547 & 0.000 & 0.502 & 0.000 \\
\hline age41_50 & 0.551 & 0.000 & 0.540 & 0.000 & 0.554 & 0.000 & 0.617 & 0.000 & 0.517 & 0.000 \\
\hline age51_70 & 0.445 & 0.000 & 0.397 & 0.000 & 0.399 & 0.000 & 0.519 & 0.000 & 0.481 & 0.000 \\
\hline tenu1_-2 & 0.104 & 0.030 & 0.055 & 0.075 & 0.039 & 0.142 & 0.000 & 0.991 & 0.028 & 0.528 \\
\hline tenu3_6 & 0.174 & 0.002 & 0.143 & 0.000 & 0.140 & 0.000 & 0.147 & 0.000 & 0.163 & 0.001 \\
\hline nu7_12 & 0.236 & 0.000 & 0.203 & 0.000 & 0.190 & 0.000 & 0.195 & 0.000 & 0.231 & 0.000 \\
\hline tenu13̄p & 0.258 & 0.000 & 0.248 & 0.000 & 0.289 & 0.000 & 0.335 & 0.000 & 0.469 & 0.000 \\
\hline stud1_4 & 0.146 & 0.011 & 0.159 & 0.000 & 0.216 & 0.000 & 0.208 & 0.000 & 0.237 & 0.000 \\
\hline tud5_8 & 0.300 & 0.000 & 0.254 & 0.000 & 0.313 & 0.000 & 0.337 & 0.000 & 0.384 & 0.000 \\
\hline stud9_11 & 0.412 & 0.000 & 0.304 & 0.000 & 0.440 & 0.000 & 0.544 & 0.000 & 0.619 & 0.000 \\
\hline stud12pl & 0.708 & 0.000 & 0.808 & 0.000 & 1.090 & 0.000 & 1.127 & 0.000 & 1.261 & 0.000 \\
\hline sec & 0.059 & 0.603 & -0.043 & 0.643 & -0.073 & 0.250 & 0.025 & 0.695 & 0.159 & 0.033 \\
\hline & -0.152 & 0.159 & -0.197 & 0.028 & -0.200 & 0.001 & -0.134 & 0.026 & 0.025 & 0.709 \\
\hline ladm & 0.496 & 0.000 & 0.615 & 0.000 & 0.657 & 0.000 & 0.670 & 0.000 & 0.663 & 0.000 \\
\hline sfor & 0.290 & 0.032 & 0.377 & 0.000 & 0.431 & 0.000 & 0.410 & 0.000 & 0.358 & 0.000 \\
\hline octracom & 0.346 & 0.011 & 0.455 & 0.000 & 0.492 & 0.000 & 0.490 & 0.000 & 0.428 & 0.000 \\
\hline ocservic & 0.321 & 0.019 & 0.385 & 0.000 & 0.398 & 0.000 & 0.447 & 0.000 & 0.333 & 0.000 \\
\hline NAoccup & 0.194 & 0.146 & 0.210 & 0.037 & 0.259 & 0.000 & 0.251 & 0.000 & 0.186 & 0.015 \\
\hline carteira & 0.438 & 0.000 & 0.366 & 0.000 & 0.288 & 0.000 & 0.218 & 0.000 & 0.146 & 0.000 \\
\hline _cons & 3.522 & 0.000 & 3.987 & 0.000 & 4.335 & 0.000 & 4.667 & 0.000 & 4.948 & 0.000 \\
\hline
\end{tabular}


Appendix C1. continued

\begin{tabular}{|c|c|c|c|c|c|c|c|c|c|c|}
\hline Pernamb, all & $\begin{array}{l}\text { Coef. } \\
\text { q10 }\end{array}$ & $P>|t|$ & $\begin{array}{l}\text { Coef. } \\
\text { q25 }\end{array}$ & $P>|t|$ & $\begin{array}{l}\text { Coef. } \\
\text { q50 }\end{array}$ & $>|t|$ & $\begin{array}{l}\text { Coef. } \\
\text { q75 }\end{array}$ & $P>|t|$ & $\begin{array}{l}\text { Coef. } \\
\text { q90 }\end{array}$ & t| \\
\hline female & -0.274 & 0.001 & -0.305 & 0.000 & -0.374 & 0.000 & -0.385 & 0.000 & -0.415 & 0.000 \\
\hline white & 194 & .006 & 0.201 & 000 & 129 & 007 & 121 & 58 & & \\
\hline nion & 0.215 & 0.017 & 0.157 & 0.0 & 0.140 & 0.034 & 0.163 & & & 0.164 \\
\hline & -0.137 & 0.413 & -0.012 & 0.918 & 0.093 & 0.434 & 0.095 & 0.407 & 0.075 & 0.571 \\
\hline & 407 & 0.000 & 0.393 & 0.000 & 0.338 & 0.000 & 0.253 & 0.000 & .272 & 0.000 \\
\hline & .164 & .029 & -0.092 & 0.077 & -0.094 & 0.079 & -0.185 & & -0.191 & 0.035 \\
\hline 1 1_30 & 0.344 & 0.006 & 0.257 & 0.004 & 0.192 & 0.055 & 0.206 & 0.051 & 0.296 & 0.012 \\
\hline 1 -40 & 0.370 & 0.007 & 0.466 & 0.000 & 0.413 & 0.000 & 0.462 & 0.000 & 0.465 & 0.000 \\
\hline-50 & 570 & 000 & 0.534 & 0.000 & 0.569 & 0.000 & 0.642 & 00 & 0.602 & 0.000 \\
\hline ge51_70 & 0.580 & 0.000 & 0.387 & 0.001 & 0.289 & 0.026 & 0.491 & 0.000 & 0.487 & 0.000 \\
\hline enu1_2 & 0.049 & 0.716 & 0.044 & 0.604 & 0.026 & 0.754 & -0.029 & 0.785 & 0.011 & 0.924 \\
\hline & 182 & 177 & 116 & 0.219 & 0.158 & 0.064 & 0.133 & 0.2 & .122 & .315 \\
\hline 12 & 0.202 & 0.205 & 0.204 & 0.051 & 0.245 & 0.027 & 0.199 & 0.105 & 0.268 & 0.040 \\
\hline & 0.178 & 0.479 & 0.204 & 0.198 & 0.425 & 0.001 & 0.251 & 0.081 & 0.204 & 0.220 \\
\hline & 0.358 & 0.010 & 0.135 & 0.160 & 0.209 & 0.004 & 0.277 & 02 & 0.273 & .008 \\
\hline & 0.501 & 0.000 & 0.279 & 0.010 & 0.338 & 0.000 & 0.500 & 0.000 & 0.525 & 0.000 \\
\hline & 0.587 & 0.000 & 0.350 & 0.011 & 0.504 & 0.000 & 0.633 & 0.000 & 0.653 & 0.000 \\
\hline & 0.695 & 0.006 & 0.716 & 0.002 & 1.250 & 0.000 & 1.328 & 0.000 & 1.301 & 0.000 \\
\hline & 0.091 & 0.780 & -0.041 & 0.879 & 0.139 & 0.437 & 0.188 & 0.213 & 0.079 & 0.775 \\
\hline & -0.025 & 0.939 & -0.159 & 0.543 & -0.017 & 0.924 & -0.062 & 0.685 & -0.088 & 0.751 \\
\hline & & 0.078 & 0.7 & 0.0 & & & 0.6 & & & 0.007 \\
\hline & 0.511 & 0.197 & 0.566 & 0.051 & 0.333 & 0.105 & 0.297 & 0.106 & 0.484 & 0.116 \\
\hline om & 0.563 & 0.148 & 0.620 & 0.029 & 0.400 & 0.057 & 0.457 & 15 & 0.514 & 0.099 \\
\hline & 0.463 & 0.224 & 0.533 & 0.051 & 0.311 & 0.116 & 0.474 & & 0.529 & 0.095 \\
\hline cup & 0.231 & 0.532 & 0.336 & 0.235 & 0.255 & 0.206 & 0.254 & 0.147 & 0.227 & 0.435 \\
\hline & 0.464 & 0.000 & 0.376 & 0.000 & 0.298 & 0.000 & 0.247 & 0.000 & 0.201 & 0.031 \\
\hline cons & 3.349 & 0.000 & 3.886 & 0.000 & 4.259 & 0.000 & 4.622 & 0.000 & 4.876 & 0.000 \\
\hline
\end{tabular}


Appendix C1. continued

\begin{tabular}{|c|c|c|c|c|c|c|c|c|c|c|}
\hline Bahia, all & $\begin{array}{c}\text { Coef. } \\
\text { q10 }\end{array}$ & $P>|t|$ & $\begin{array}{c}\text { Coef. } \\
\text { q25 }\end{array}$ & $P>|t|$ & $\begin{array}{c}\text { Coef. } \\
\text { q50 }\end{array}$ & $P>|t|$ & $\begin{array}{c}\text { Coef. } \\
\text { q75 }\end{array}$ & $P>|t|$ & $\begin{array}{c}\text { Coef. } \\
\text { q90 }\end{array}$ & $P>|t|$ \\
\hline female & -0.327 & 0.000 & -0.333 & 0.000 & -0.375 & 0.000 & -0.398 & 0.000 & -0.409 & 0.000 \\
\hline white & 125 & 031 & 0.085 & 0.061 & 0.114 & 007 & 076 & .123 & 0.139 & 0.020 \\
\hline union & 0.136 & 0.078 & 0.119 & 0.028 & 0.126 & 0.026 & 0.145 & 0.083 & 0.136 & 0.135 \\
\hline & 0.089 & 0.387 & 0.131 & 0.131 & 0.145 & 0.042 & 0.105 & 0.209 & 0.037 & 0.749 \\
\hline opol & 0.352 & 0.000 & 0.357 & 0.000 & 0.365 & 0.000 & 0.318 & 0.000 & 0.225 & 0.000 \\
\hline & -0.065 & 0.331 & -0.035 & 0.458 & -0.076 & 0.096 & -0.033 & 0.517 & -0.024 & 0.677 \\
\hline age21_30 & 0.512 & 0.010 & 0.375 & 0.000 & 0.339 & 0.000 & 0.335 & 0.000 & 0.243 & 0.002 \\
\hline age31_40 & 0.648 & 0.001 & 0.498 & 0.000 & 0.491 & 0.000 & 0.550 & 0.000 & 0.491 & 0.000 \\
\hline 1_50 & 0.771 & 0.000 & 0.618 & 0.000 & 0.595 & 0.000 & 0.524 & 0.000 & 0.493 & 0.000 \\
\hline age51_70 & 0.643 & 0.004 & 0.425 & 0.000 & 0.446 & 0.000 & 0.540 & 0.000 & 0.451 & 0.000 \\
\hline tenu1_- & -0.008 & 0.935 & 0.108 & 0.070 & 0.081 & 0.133 & 0.076 & 0.187 & 0.080 & 0.225 \\
\hline & 0.066 & 0.498 & 0.169 & 0.010 & 0.168 & 0.004 & 0.183 & 0.010 & 0.304 & 0.001 \\
\hline $17-12$ & -0.003 & 0.980 & 0.138 & 0.156 & 0.272 & 0.001 & 0.249 & 0.003 & 0.306 & 0.007 \\
\hline $11 \overline{3} p$ & 0.136 & 0.366 & 0.274 & 0.005 & 0.424 & 0.000 & 0.604 & 0.000 & 0.620 & 0.000 \\
\hline & 0.034 & 0.693 & 0.090 & 0.117 & 0.202 & 0.000 & 0.259 & 0.000 & 0.245 & 0.006 \\
\hline d5_8 & 0.063 & 0.574 & 0.193 & 0.010 & 0.298 & 0.000 & 0.377 & 0.000 & 0.385 & 0.000 \\
\hline d9_11 & 0.322 & 0.015 & 0.226 & 0.009 & 0.390 & 0.000 & 0.527 & 0.000 & 0.657 & 0.000 \\
\hline$\overline{2} \mathrm{pl}$ & 0.825 & 0.000 & 0.785 & 0.000 & 1.151 & 0.000 & 1.348 & 0.000 & 1.362 & 0.000 \\
\hline & -0.010 & 0.958 & 0.140 & 0.336 & 0.076 & 0.616 & 0.171 & 0.178 & 0.348 & 0.003 \\
\hline & -0.140 & 0.469 & -0.055 & 0.708 & -0.070 & 0.627 & 0.035 & 0.774 & 0.268 & 0.017 \\
\hline IUII & 0.449 & 0.046 & 0.385 & 0.028 & 0.336 & 0.043 & 0.372 & 0.027 & 0.431 & 0.022 \\
\hline & 0.277 & 0.230 & 0.036 & 0.830 & 0.118 & 0.454 & 0.047 & 0.759 & 0.043 & 0.749 \\
\hline racom & 0.125 & 0.647 & 0.126 & 0.484 & 0.135 & 0.382 & 0.131 & 0.424 & 0.223 & 0.132 \\
\hline ervic & 0.279 & 0.242 & 0.123 & 0.474 & 0.107 & 0.515 & 0.129 & 0.438 & 0.126 & 0.407 \\
\hline occup & 0.022 & 0.921 & -0.018 & 0.912 & -0.028 & 0.860 & -0.010 & 0.949 & 0.021 & 0.871 \\
\hline carteira & 0.465 & 0.000 & 0.378 & 0.000 & 0.294 & 0.000 & 0.224 & 0.000 & 0.187 & 0.001 \\
\hline cons & 3.805 & 0.000 & 4.137 & 0.000 & 4.423 & 0.000 & 4.720 & 0.000 & 4.952 & 0.000 \\
\hline
\end{tabular}


Appendix C1. continued

\begin{tabular}{|c|c|c|c|c|c|c|c|c|c|c|}
\hline Ceara, all & $\begin{array}{c}\text { Coef. } \\
\text { q10 }\end{array}$ & $P>|t|$ & $\begin{array}{c}\text { Coef. } \\
\text { q25 }\end{array}$ & $P>|t|$ & $\begin{array}{c}\text { Coef. } \\
\text { q50 }\end{array}$ & $P>|t|$ & $\begin{array}{c}\text { Coef. } \\
\text { q75 }\end{array}$ & $P>|t|$ & $\begin{array}{c}\text { Coef. } \\
\text { q90 }\end{array}$ & $P>|t|$ \\
\hline \multirow[t]{2}{*}{ female } & - & 0,001 & - & 0,000 & - & 0,000 & - & 0,000 & - & 0,000 \\
\hline & 0,346 & & 0,428 & & 0,539 & & 0,576 & & 0,658 & \\
\hline white & 0,140 & 0,119 & 0,131 & 0,016 & 0,147 & 0,013 & 0,148 & 0,038 & 0,205 & 0,007 \\
\hline union & 199 & 0,080 & 0,216 & 0,001 & 0,198 & 0,011 & 0,117 & 0,140 & 0,203 & 0,055 \\
\hline urban & 0,064 & 0,739 & 0,081 & 0,589 & 0,006 & 0,955 & $\begin{array}{c}- \\
0.032\end{array}$ & 0,793 & $\begin{array}{c}- \\
0.073\end{array}$ & 0,605 \\
\hline metropol & 0,587 & 0,000 & 0,439 & 0,000 & 0,385 & 0,000 & 0,313 & 0,000 & 0,337 & 0,000 \\
\hline \multirow[t]{2}{*}{ liveten } & - & 0,096 & - & 0,030 & - & 0,037 & - & 0,024 & - & 0,010 \\
\hline & 0,161 & & 0,140 & & 0,148 & & 0,198 & & 0,218 & \\
\hline age21_30 & 0,511 & 0,004 & 0,397 & 0,000 & 0,325 & 0,001 & 0,405 & 0,000 & 0,301 & 0,011 \\
\hline age31_40 & 0,403 & 0,048 & 0,487 & 0,000 & 0,590 & 0,000 & 0,616 & 0,000 & 0,641 & 0,000 \\
\hline age41_50 & 0,494 & 0,030 & 0,508 & 0,000 & 0,604 & 0,000 & 0,691 & 0,000 & 0,498 & 0,001 \\
\hline age51_70 & 0,384 & 0,083 & 0,358 & 0,005 & 0,516 & 0,000 & 0,562 & 0,000 & 0,654 & 0,000 \\
\hline tenu1_2 & 0,260 & 0,162 & 0,179 & 0,168 & 0,072 & 0,441 & 0,034 & 0,745 & 0,024 & 0,838 \\
\hline tenu3_6 & 0,378 & 0,062 & 0,259 & 0,057 & 0,124 & 0,229 & 0,193 & 0,111 & 0,189 & 0,158 \\
\hline tenu7_12 & 0,525 & 0,011 & 0,325 & 0,023 & 0,249 & 0,036 & 0,258 & 0,033 & 0,181 & 0,170 \\
\hline tenu13̄p & 0,642 & 0,006 & 0,433 & 0,005 & 0,218 & 0,058 & 0,276 & 0,085 & 0,269 & 0,223 \\
\hline stud1_4 & 0,067 & 0,576 & 0,210 & 0,018 & 0,297 & 0,000 & 0,257 & 0,007 & 0,093 & 0,358 \\
\hline stud5_8 & 0,206 & 0,120 & 0,245 & 0,004 & 0,351 & 0,000 & 0,347 & 0,001 & 0,229 & 0,028 \\
\hline stud9_11 & 0,296 & 0,078 & 0,369 & 0,002 & 0,609 & 0,000 & 0,638 & 0,000 & 0,663 & 0,000 \\
\hline stud12̄pl & 0,383 & 0,121 & 0,678 & 0,000 & 0,716 & 0,001 & 0,974 & 0,000 & 0,719 & 0,002 \\
\hline secsec & $\overline{-}, \overline{438}$ & 0,084 & $0, \overline{239}$ & 0,209 & 0, & 0,630 & 0,175 & 0,334 & 0,374 & 0,106 \\
\hline tertsec & $\overline{-}, 413$ & 0,054 & 0,404 & 0,008 & $\begin{array}{c}- \\
0,224\end{array}$ & 0,162 & 0,058 & 0,716 & 0,080 & 0,715 \\
\hline $\mathrm{dm}$ & 0,605 & 0,027 & 0,913 & 0,000 & 0,955 & 0,000 & 1,058 & 0,000 & 1,233 & 0,000 \\
\hline transfor & 0,687 & 0,025 & 0,718 & 0,004 & 0,652 & 0,001 & 0,650 & 0,001 & 0,582 & 0,013 \\
\hline octracom & 0,558 & 0,054 & 0,716 & 0,002 & 0,629 & 0,003 & 0,687 & 0,000 & 0,779 & 0,003 \\
\hline ocservic & 0,356 & 0,174 & 0,699 & 0,001 & 0,592 & 0,003 & 0,593 & 0,001 & 0,750 & 0,002 \\
\hline NAoccup & 0,427 & 0,171 & 0,565 & 0,010 & 0,412 & 0,035 & 0,348 & 0,058 & 0,432 & 0,070 \\
\hline carteira & 0,404 & 0,002 & 0,317 & 0,000 & 0,163 & 0,015 & 0,142 & 0,096 & 0,005 & 0,957 \\
\hline cons & 3,418 & 0,000 & 3,711 & 0,000 & 4,214 & 0,000 & 4,402 & 0,000 & 4,858 & 0,000 \\
\hline
\end{tabular}


Appendix C2. Quantile regressions including males only

\begin{tabular}{|c|c|c|c|c|c|c|c|c|c|c|}
\hline NE, males & $\begin{array}{c}\text { Coef. } \\
\text { q10 }\end{array}$ & $P>|t|$ & $\begin{array}{c}\text { Coef. } \\
\text { q25 }\end{array}$ & $P>|t|$ & $\begin{array}{c}\text { Coef. } \\
\text { q50 }\end{array}$ & $P>|t|$ & $\begin{array}{c}\text { Coef. } \\
\text { q75 }\end{array}$ & $P>|t|$ & $\begin{array}{c}\text { Coef. } \\
\text { q90 }\end{array}$ & $P>|t|$ \\
\hline white & 0.139 & 0.003 & 0.155 & 0.000 & 0.177 & 0.000 & 0.163 & 0.000 & 0.163 & 0.000 \\
\hline union & 183 & 0.000 & 0.148 & 0.000 & 0.125 & 0.000 & 0.151 & 0.000 & 0.162 & 0.004 \\
\hline & -0.001 & 0.992 & 0.054 & 0.359 & 0.029 & 0.561 & 0.037 & 0.544 & 0.074 & 0.203 \\
\hline opol & .224 & 0.000 & 0.254 & 0.000 & 0.250 & 0.000 & 0.195 & 0.000 & 0.132 & 0.001 \\
\hline & -0.178 & 0.000 & -0.124 & 0.000 & -0.113 & 0.000 & -0.130 & 0.000 & -0.094 & 0.047 \\
\hline e21_30 & 0.425 & 0.000 & 0.344 & 0.000 & 0.361 & 0.000 & 0.384 & 0.000 & 0.366 & 0.000 \\
\hline e31_40 & 0.692 & 0.000 & 0.584 & 0.000 & 0.612 & 0.000 & 0.643 & 0.000 & 0.614 & 0.000 \\
\hline e41_50 & 0.757 & 0.000 & 0.635 & 0.000 & 0.666 & 0.000 & 0.733 & 0.000 & 0.643 & 0.000 \\
\hline ge51_70 & 0.546 & 0.000 & 0.506 & 0.000 & 0.509 & 0.000 & 0.592 & 0.000 & 0.563 & 0.000 \\
\hline enu1_-2 & 0.130 & 0.088 & 0.100 & 0.040 & 0.066 & 0.095 & 0.050 & 0.332 & 0.070 & 0.208 \\
\hline & 0.221 & 0.010 & 0.158 & 0.004 & 0.183 & 0.000 & 0.206 & 0.000 & 0.229 & 0.000 \\
\hline $7-12$ & 0.275 & 0.002 & 0.274 & 0.000 & 0.262 & 0.000 & 0.257 & 0.000 & 0.252 & 0.000 \\
\hline $1 \overline{3} p$ & 0.345 & 0.003 & 0.308 & 0.000 & 0.297 & 0.000 & 0.350 & 0.000 & 0.499 & 0.000 \\
\hline & 0.134 & 0.064 & 0.163 & 0.001 & 0.205 & 0.000 & 0.231 & 0.000 & 0.276 & 0.000 \\
\hline & 0.277 & 0.000 & 0.266 & 0.000 & 0.336 & 0.000 & 0.409 & 0.000 & 0.441 & 0.000 \\
\hline 9_11 & 0.454 & 0.000 & 0.366 & 0.000 & 0.498 & 0.000 & 0.656 & 0.000 & 0.752 & 0.000 \\
\hline$\overline{2} \mathrm{pl}$ & 0.797 & 0.000 & 0.856 & 0.000 & 1.184 & 0.000 & 1.181 & 0.000 & 1.312 & 0.000 \\
\hline & 0.173 & 0.262 & 0.164 & 0.058 & 0.065 & 0.533 & 0.093 & 0.215 & 0.194 & 0.053 \\
\hline & 0.048 & 0.753 & 0.067 & 0.464 & -0.005 & 0.967 & -0.019 & 0.791 & 0.060 & 0.530 \\
\hline & 0.435 & 0.009 & 0.413 & 0.000 & 0.501 & 0.000 & 0.580 & 0.000 & 0.555 & 0.000 \\
\hline & 0.287 & 0.090 & 0.189 & 0.066 & 0.307 & 0.004 & 0.379 & 0.000 & 0.371 & 0.001 \\
\hline com & 0.296 & 0.099 & 0.264 & 0.014 & 0.316 & 0.007 & 0.401 & 0.000 & 0.380 & 0.001 \\
\hline & 0.092 & 0.604 & 0.090 & 0.445 & 0.198 & 0.114 & 0.395 & 0.000 & 0.341 & 0.006 \\
\hline NAoccup & 0.064 & 0.702 & -0.022 & 0.831 & 0.090 & 0.423 & 0.168 & 0.046 & 0.154 & 0.168 \\
\hline carteira & 0.518 & 0.000 & 0.437 & 0.000 & 0.311 & 0.000 & 0.198 & 0.000 & 0.139 & 0.005 \\
\hline cons & 3.405 & 0.000 & 3.880 & 0.000 & 4.257 & 0.000 & 4.575 & 0.000 & 4.821 & 0.000 \\
\hline
\end{tabular}


Appendix C2. continued

\begin{tabular}{|c|c|c|c|c|c|c|c|c|c|c|}
\hline $\begin{array}{l}\text { Pernamb, } \\
\text { males }\end{array}$ & Coef. & $P>|t|$ & Coef. & $P>|t|$ & Coef. & $P>|t|$ & q75 & $P>|t|$ & Coef. & $P>|t|$ \\
\hline white & 0.186 & 0.062 & 0.155 & 0.031 & 0.094 & 0.187 & 0.175 & 0.007 & 0.197 & 0.036 \\
\hline union & 0.188 & 0.103 & 0.037 & 0.666 & 0.073 & 0.435 & 0.243 & 0.008 & 0.313 & 0.003 \\
\hline rban & -0.154 & 0.455 & 0.019 & 0.886 & 0.092 & 0.493 & 0.150 & 0.349 & -0.123 & 0.530 \\
\hline etropol & 0.361 & 0.001 & 0.313 & 0.001 & 0.282 & 0.002 & 0.126 & 0.078 & 0.119 & 0.239 \\
\hline reten & -0.288 & 0.005 & -0.211 & 0.008 & -0.213 & 0.006 & -0.235 & 0.005 & -0.229 & 0.082 \\
\hline age21_30 & 0.639 & 0.003 & 0.458 & 0.000 & 0.275 & 0.033 & 0.308 & 0.036 & 0.363 & 0.028 \\
\hline ge31_40 & 0.780 & 0.002 & 0.663 & 0.000 & 0.515 & 0.000 & 0.578 & 0.000 & 0.507 & 0.001 \\
\hline ge41_50 & 0.944 & 0.000 & 0.784 & 0.000 & 0.690 & 0.000 & 0.779 & 0.000 & 0.679 & 0.000 \\
\hline age51_70 & 0.946 & 0.000 & 0.619 & 0.000 & 0.456 & 0.004 & 0.621 & 0.000 & 0.530 & 0.005 \\
\hline nu1_2 & 0.173 & 0.242 & 0.098 & 0.441 & 0.112 & 0.276 & 0.164 & 0.100 & 0.292 & 0.060 \\
\hline nu3_6 & 0.202 & 0.158 & 0.089 & 0.494 & 0.161 & 0.153 & 0.190 & 0.104 & 0.396 & 0.022 \\
\hline nu7_-12 & 0.227 & 0.217 & 0.203 & 0.161 & 0.333 & 0.013 & 0.334 & 0.006 & 0.471 & 0.005 \\
\hline & 0.139 & 0.566 & 0.247 & 0.157 & 0.356 & 0.037 & 0.376 & 0.013 & 0.542 & 0.010 \\
\hline ud1_4 & 0.299 & 0.105 & 0.113 & 0.336 & 0.169 & 0.097 & 0.138 & 0.165 & 0.203 & 0.098 \\
\hline ud5_8 & 0.454 & 0.026 & 0.253 & 0.060 & 0.327 & 0.005 & 0.374 & 0.003 & 0.574 & 0.000 \\
\hline & 0.737 & 0.001 & 0.421 & 0.008 & 0.557 & 0.000 & 0.581 & 0.000 & 0.775 & 0.000 \\
\hline ud12 $\mathrm{pl}$ & 0.342 & 0.320 & 0.579 & 0.056 & 1.237 & 0.000 & 1.168 & 0.000 & 1.220 & 0.000 \\
\hline $\operatorname{csec}$ & 0.260 & 0.520 & 0.081 & 0.789 & 0.276 & 0.392 & 0.269 & 0.197 & 0.284 & 0.343 \\
\hline & & 0.676 & 0.034 & 0.913 & 0.184 & 0.560 & 91 & 0.671 & 0.105 & 0.740 \\
\hline adm & 0.692 & 0.126 & 0.661 & 0.028 & 0.459 & 0.119 & 0.695 & 0.003 & 0.699 & 0.060 \\
\hline transfor & 0.535 & 0.251 & 0.489 & 0.101 & 0.274 & 0.361 & 0.376 & 0.050 & 0.293 & 0.372 \\
\hline octracom & 0.512 & 0.274 & 0.482 & 0.127 & 0.279 & 0.378 & 0.495 & 0.011 & 0.493 & 0.135 \\
\hline ocservic & 0.290 & 0.556 & 0.210 & 0.514 & 0.177 & 0.577 & 0.460 & 0.062 & 0.378 & 0.348 \\
\hline NAoccup & 0.261 & 0.564 & 0.263 & 0.373 & 0.211 & 0.481 & 0.272 & 0.140 & 0.217 & 0.494 \\
\hline carteira & 0.236 & 0.070 & 0.388 & 0.000 & 0.339 & 0.000 & 0.263 & 0.004 & 0.109 & 0.398 \\
\hline cons & 3.153 & 0.000 & 3.793 & 0.000 & 4.149 & 0.000 & 4.358 & 0.000 & 4.787 & 0.000 \\
\hline
\end{tabular}


Appendix C2. continued

\begin{tabular}{|c|c|c|c|c|c|c|c|c|c|c|}
\hline Bahia, males & $\begin{array}{c}\text { Coef. } \\
\text { q10 }\end{array}$ & $P>|t|$ & $\begin{array}{c}\text { Coef. } \\
\text { q25 }\end{array}$ & $P>|t|$ & $\begin{array}{c}\text { Coef. } \\
\text { q50 }\end{array}$ & $P>|t|$ & $\begin{array}{c}\text { Coef. } \\
\text { q75 }\end{array}$ & $P>|t|$ & $\begin{array}{c}\text { Coef. } \\
\text { q90 }\end{array}$ & $P>|t|$ \\
\hline white & 0.130 & 0.113 & 0.146 & 0.014 & 0.128 & 0.014 & 0.090 & 0.131 & 0.159 & 0.066 \\
\hline union & 107 & 263 & 168 & .014 & 0.057 & 379 & .029 & 0.723 & 076 & 0.502 \\
\hline$n$ & 44 & 302 & 0.224 & 0.028 & 0.209 & 0.054 & 0.120 & 0.310 & .116 & 0.356 \\
\hline & 0.264 & 0.010 & 0.195 & 0.007 & 0.257 & 0.000 & 0.259 & 0.000 & 0.175 & 0.026 \\
\hline liveten & -0.070 & 0.488 & -0.041 & 0.515 & -0.054 & 0.435 & 0.007 & 0.914 & 0.014 & 0.864 \\
\hline age21_30 & 0.659 & 0.018 & 0.390 & 0.000 & 0.438 & 0.000 & 0.389 & 0.000 & .416 & 0.000 \\
\hline age31_40 & 0.980 & 0.000 & 0.614 & 0.000 & 0.637 & 0.000 & 0.570 & 0.000 & 0.665 & 0.000 \\
\hline ge41_50 & 1.037 & 0.000 & 0.671 & 0.000 & 0.717 & 0.000 & 0.671 & 0.000 & 0.650 & 0.000 \\
\hline 70 & 855 & 0.002 & 0.546 & .000 & 0.609 & 0.000 & 0.564 & 0.000 & 0.634 & 0.000 \\
\hline tenu1_2 & 0.075 & 0.571 & 0.104 & 0.190 & 0.086 & 0.317 & 0.000 & 0.996 & 0.040 & 0.663 \\
\hline nu3_6 & 0.218 & 0.145 & 0.163 & 0.073 & 0.194 & 0.041 & 0.092 & 0.351 & 0.158 & 0.172 \\
\hline & 0.032 & 0.874 & 0.125 & 0.328 & 0.254 & 0.028 & 0.175 & 0.150 & .328 & 0.038 \\
\hline & 0.170 & 0.307 & 0.299 & 0.010 & 0.377 & 0.009 & 0.488 & 0.009 & 0.565 & 0.003 \\
\hline 144 & 0.032 & 0.795 & 0.077 & 0.345 & 0.221 & 0.002 & 0.299 & 0.000 & 0.380 & 0.003 \\
\hline & 0.207 & 0.136 & 0.221 & 0.027 & 0.369 & 0.000 & 0.449 & 0.000 & 0.581 & 0.000 \\
\hline d9_11 & 0.244 & 0.204 & 0.132 & 0.280 & 0.389 & 0.002 & 0.541 & 0.000 & 0.686 & 0.000 \\
\hline $\mathrm{d} 1 \overline{2} \mathrm{pl}$ & 1.057 & 0.000 & 0.883 & 0.000 & 1.202 & 0.000 & 1.187 & 0.000 & 1.228 & 0.003 \\
\hline & 0.022 & 0.951 & 0.370 & 0.089 & 0.107 & 0.554 & 0.253 & 0.174 & 0.262 & 0.186 \\
\hline & -0.296 & 0.417 & 0.220 & 0.350 & 0.018 & 0.926 & 0.190 & 0.315 & 0.092 & 0.654 \\
\hline adm & 0.506 & 0.164 & 0.234 & 0.289 & 0.340 & 0.077 & 0.239 & 0.237 & 0.530 & 0.061 \\
\hline & 0.222 & 0.529 & -0.055 & 0.792 & 0.180 & 0.253 & 0.024 & 0.893 & 0.210 & 0.306 \\
\hline racom & 0.309 & 0.438 & -0.011 & 0.961 & 0.163 & 0.361 & 0.115 & 0.589 & 0.326 & 0.117 \\
\hline ervic & 0.347 & 0.458 & 0.070 & 0.799 & 0.026 & 0.903 & -0.003 & 0.990 & 0.316 & 0.232 \\
\hline occup & 0.010 & 0.979 & -0.248 & 0.286 & -0.100 & 0.554 & -0.130 & 0.521 & 0.054 & 0.801 \\
\hline carteira & 0.643 & 0.000 & 0.420 & 0.000 & 0.263 & 0.000 & 0.220 & 0.001 & 0.198 & 0.012 \\
\hline cons & 3.386 & 0.000 & 3.932 & 0.000 & 4.261 & 0.000 & 4.664 & 0.000 & 4.660 & 0.000 \\
\hline
\end{tabular}


Appendix C2. continued

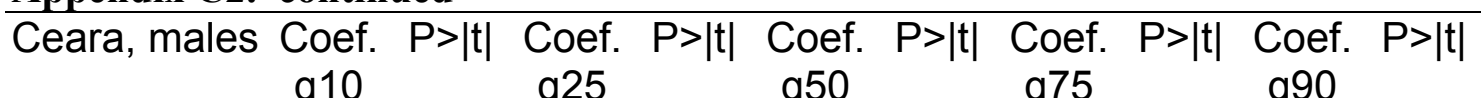
\begin{tabular}{lllllllllllll}
\hline white & 0,177 & 0,130 & 0,146 & 0,092 & 0,123 & 0,093 & 0,140 & 0,094 & 0,213 & 0,056
\end{tabular} $\begin{array}{llllllllllllll}\text { union } & 0,212 & 0,109 & 0,182 & 0,056 & 0,047 & 0,631 & 0,033 & 0,738 & 0,226 & 0,050\end{array}$ urban $\quad 0,2290,3250,2080,252-0,0350,8140,0810,544-0,0960,544$ metropol $\quad 0,3310,0200,363 \quad 0,000 \quad 0,3050,000 \quad 0,294 \quad 0,0010,2120,055$ liveten $\quad-0,2650,025-0,1460,111-0,2390,011-0,1380,184-0,2550,016$ age21_30 $\quad 0,416 \quad 0,042 \quad 0,279 \quad 0,104 \quad 0,328 \quad 0,026 \quad 0,352 \quad 0,024 \quad 0,384 \quad 0,014$ $\begin{array}{lllllllllllll}\text { age31_40 } & 0,311 & 0,179 & 0,332 & 0,073 & 0,620 & 0,000 & 0,672 & 0,000 & 0,759 & 0,000\end{array}$ $\begin{array}{llllllllllllllllllllllll}\text { age41_50 } & 0,537 & 0,025 & 0,419 & 0,042 & 0,680 & 0,000 & 0,676 & 0,000 & 0,644 & 0,001\end{array}$ age51_70 tenu1_2 tenu3 6 tenu7_12 tenu13 $p$ stud1_4 stud5_8 stud9_11 stud12 pl secsec tertsec techadm transfor octracom ocservic NAoccup carteira $\begin{array}{lllllllllllllllllllll}0,338 & 0,198 & 0,240 & 0,285 & 0,592 & 0,001 & 0,428 & 0,013 & 0,727 & 0,001\end{array}$ $0,3000,1920,1550,3590,0570,700-0,0970,543-0,0680,671$ $\begin{array}{llllllllllllllllllll}0,496 & 0,044 & 0,322 & 0,049 & 0,152 & 0,388 & 0,153 & 0,390 & 0,158 & 0,370\end{array}$ $\begin{array}{lllllllllllllllllllllll}0,550 & 0,029 & 0,493 & 0,007 & 0,348 & 0,038 & 0,155 & 0,394 & 0,124 & 0,508\end{array}$

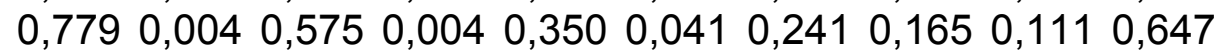
$\begin{array}{lllllllllllll}0,072 & 0,668 & 0,227 & 0,054 & 0,313 & 0,003 & 0,272 & 0,012 & 0,026 & 0,859\end{array}$ $\begin{array}{llllllllllllll}0,039 & 0,825 & 0,152 & 0,307 & 0,322 & 0,008 & 0,330 & 0,012 & 0,218 & 0,136\end{array}$ $\begin{array}{lllllllllllllllllll}0,202 & 0,386 & 0,406 & 0,059 & 0,733 & 0,000 & 0,763 & 0,000 & 0,864 & 0,000\end{array}$ $\begin{array}{llllllllllllllllllll}0,190 & 0,547 & 0,657 & 0,044 & 0,744 & 0,031 & 1,173 & 0,000 & 0,943 & 0,000\end{array}$ $\begin{array}{lllllllllllllllllll}-0,204 & 0,493 & -0,020 & 0,935 & 0,070 & 0,745 & 0,114 & 0,575 & 0,266 & 0,315\end{array}$ $-0,2580,352-0,1900,437-0,0350,876-0,0050,982-0,0060,984$ $\begin{array}{llllllllllllllll}0,775 & 0,024 & 0,756 & 0,016 & 0,928 & 0,000 & 1,148 & 0,000 & 1,240 & 0,000\end{array}$ $\begin{array}{llllllllllllllllll}0,610 & 0,083 & 0,502 & 0,104 & 0,607 & 0,010 & 0,793 & 0,000 & 0,770 & 0,011\end{array}$ $\begin{array}{llllllllllllllllllll}0,565 & 0,153 & 0,526 & 0,092 & 0,586 & 0,024 & 0,805 & 0,002 & 1,018 & 0,004\end{array}$ $\begin{array}{lllllllllllllllllllll}0,513 & 0,139 & 0,528 & 0,073 & 0,526 & 0,031 & 0,723 & 0,002 & 0,804 & 0,019\end{array}$ $\begin{array}{lllllllllllllllllllllll}0,222 & 0,541 & 0,334 & 0,265 & 0,282 & 0,238 & 0,431 & 0,036 & 0,616 & 0,051\end{array}$ _cons $\begin{array}{llllllllllll}0,665 & 0,000 & 0,460 & 0,000 & 0,237 & 0,017 & 0,025 & 0,825 & -0,113 & 0,395\end{array}$

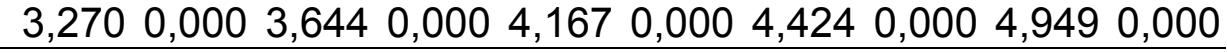


Appendix C3. Quantile regressions including females

\begin{tabular}{|c|c|c|c|c|c|c|c|c|c|c|}
\hline NE, females & $\begin{array}{c}\text { Coef. } \\
\text { q10 }\end{array}$ & $P>|t|$ & $\begin{array}{c}\text { Coef. } \\
\text { q25 }\end{array}$ & $P>|t|$ & $\begin{array}{c}\text { Coef. } \\
\text { q50 }\end{array}$ & $P>|t|$ & $\begin{array}{c}\text { Coef. } \\
\text { q75 }\end{array}$ & $P>|t|$ & $\begin{array}{c}\text { Coef. } \\
\text { q90 }\end{array}$ & $P>|t|$ \\
\hline white & 0.124 & 0.008 & 0.132 & 0.000 & 0.171 & 0.000 & 0.209 & 0.000 & 0.194 & 0.000 \\
\hline union & 0.207 & 0.009 & 0.187 & 0.001 & 0.201 & 0.000 & 0.113 & 0.085 & 0.154 & 0.076 \\
\hline rban & 0.158 & 0.048 & 0.150 & 0.086 & 0.076 & 0.152 & 0.036 & 0.657 & -0.048 & 0.675 \\
\hline ietropol & 0.364 & 0.000 & 0.410 & 0.000 & 0.415 & 0.000 & 0.374 & 0.000 & 0.279 & 0.000 \\
\hline veten & 0.025 & 0.656 & -0.074 & 0.042 & -0.068 & 0.028 & -0.048 & 0.216 & 0.001 & 0.985 \\
\hline $21 \quad 30$ & 323 & 0.002 & 0.225 & 0.000 & 0.209 & 0.000 & 0.216 & 0.000 & 0.174 & 0.006 \\
\hline ge31_40 & 0.216 & 0.034 & 0.242 & 0.000 & 0.366 & 0.000 & 0.380 & 0.000 & 0.326 & 0.000 \\
\hline ge41_50 & 0.302 & 0.004 & 0.343 & 0.000 & 0.401 & 0.000 & 0.420 & 0.000 & 0.330 & 0.000 \\
\hline ge51_70 & 0.258 & 0.021 & 0.229 & 0.002 & 0.265 & 0.001 & 0.319 & 0.002 & 0.386 & 0.000 \\
\hline nu1_2 & 0.050 & 0.511 & 0.035 & 0.456 & -0.016 & 0.667 & 0.016 & 0.742 & -0.063 & 0.330 \\
\hline nu3_6 & 0.100 & 0.195 & 0.162 & 0.003 & 0.090 & 0.026 & 0.144 & 0.010 & 0.077 & 0.263 \\
\hline u7_12 & 0.239 & 0.004 & 0.167 & 0.007 & 0.118 & 0.035 & 0.240 & 0.001 & 0.146 & 0.138 \\
\hline $11 \overline{3} p$ & 0.191 & 0.059 & 0.213 & 0.012 & 0.292 & 0.000 & 0.345 & 0.001 & 0.400 & 0.001 \\
\hline ud1_4 & 0.127 & 0.121 & 0.173 & 0.002 & 0.207 & 0.000 & 0.184 & 0.000 & 0.155 & 0.022 \\
\hline d5_8 & 0.261 & 0.000 & 0.231 & 0.000 & 0.249 & 0.000 & 0.237 & 0.000 & 0.258 & 0.003 \\
\hline $19 \quad 11$ & 0.307 & 0.000 & 0.235 & 0.000 & 0.296 & 0.000 & 0.410 & 0.000 & 0.420 & 0.000 \\
\hline ud12pl & 0.730 & 0.000 & 0.669 & 0.000 & 0.887 & 0.000 & 1.122 & 0.000 & 1.197 & 0.000 \\
\hline $\sec$ & -0.300 & 0.147 & -0.289 & 0.041 & -0.137 & 0.142 & -0.058 & 0.614 & 0.186 & 0.149 \\
\hline & -0.499 & 0.008 & -0.528 & 0.000 & -0.358 & 0.000 & -0.250 & 0.013 & 0.002 & 0.988 \\
\hline adm & 0.576 & 0.046 & 0.932 & 0.000 & 0.885 & 0.002 & 0.544 & 0.018 & 0.692 & 0.000 \\
\hline sfor & 0.329 & 0.296 & 0.581 & 0.001 & 0.581 & 0.037 & 0.222 & 0.342 & 0.144 & 0.498 \\
\hline octracom & 0.509 & 0.100 & 0.708 & 0.000 & 0.693 & 0.014 & 0.303 & 0.183 & 0.401 & 0.041 \\
\hline ocservic & 0.440 & 0.126 & 0.662 & 0.000 & 0.592 & 0.033 & 0.284 & 0.213 & 0.298 & 0.104 \\
\hline Aoccup & 0.329 & 0.266 & 0.563 & 0.001 & 0.518 & 0.056 & 0.150 & 0.508 & 0.211 & 0.257 \\
\hline carteira & 0.366 & 0.000 & 0.297 & 0.000 & 0.241 & 0.000 & 0.196 & 0.000 & 0.138 & 0.005 \\
\hline cons & 3.508 & 0.000 & 3.737 & 0.000 & 3.987 & 0.000 & 4.565 & 0.000 & 4.859 & 0.000 \\
\hline
\end{tabular}


Appendix C3. continued

\begin{tabular}{|c|c|c|c|c|c|c|c|c|c|c|}
\hline $\begin{array}{l}\text { Pernamb, } \\
\text { females }\end{array}$ & Coef. & $P>|t|$ & Coef. & $P>|t|$ & q50 & $P>|t|$ & q75 & $P>|t|$ & Coef. & $P>|t|$ \\
\hline white & 0.248 & 0.015 & 0.320 & 0.000 & 0.178 & 0.036 & 0.191 & 0.023 & 0.140 & 0.267 \\
\hline union & 0.395 & 0.010 & 0.326 & 0.005 & 0.220 & 0.071 & -0.081 & 0.564 & -0.156 & 0.379 \\
\hline fban & 0.030 & 0.917 & 0.078 & 0.783 & 0.224 & 0.338 & 0.008 & 0.965 & 0.071 & 0.752 \\
\hline etropol & 0.434 & 0.000 & 0.407 & 0.000 & 0.377 & 0.001 & 0.450 & 0.000 & 0.445 & 0.001 \\
\hline veten & -0.071 & 0.500 & -0.024 & 0.741 & -0.002 & 0.986 & 0.018 & 0.851 & -0.169 & 0.295 \\
\hline age21_30 & 0.141 & 0.329 & 0.148 & 0.176 & 0.064 & 0.653 & 0.168 & 0.178 & 0.242 & 0.269 \\
\hline ge31_40 & 0.203 & 0.281 & 0.221 & 0.071 & 0.250 & 0.093 & 0.264 & 0.052 & 0.335 & 0.135 \\
\hline ge41_50 & 0.112 & 0.584 & 0.286 & 0.034 & 0.307 & 0.056 & 0.292 & 0.060 & 0.511 & 0.037 \\
\hline age51_70 & 0.377 & 0.147 & 0.212 & 0.317 & 0.140 & 0.507 & 0.207 & 0.264 & 0.318 & 0.180 \\
\hline nu1_2 & -0.040 & 0.785 & 0.053 & 0.618 & -0.005 & 0.976 & -0.146 & 0.354 & -0.194 & 0.595 \\
\hline nu3_6 & 0.264 & 0.136 & 0.361 & 0.005 & 0.191 & 0.229 & -0.014 & 0.926 & -0.128 & 0.715 \\
\hline nu7_-12 & 0.135 & 0.529 & 0.347 & 0.042 & 0.191 & 0.378 & 0.216 & 0.362 & 0.189 & 0.654 \\
\hline $1 \overline{3} p$ & 0.356 & 0.301 & 0.544 & 0.109 & 0.494 & 0.028 & 0.098 & 0.652 & 0.250 & 0.545 \\
\hline 1144 & 0.384 & 0.118 & 0.227 & 0.284 & 0.127 & 0.378 & 0.315 & 0.048 & 0.161 & 0.452 \\
\hline $15 \_8$ & 0.394 & 0.085 & 0.336 & 0.130 & 0.303 & 0.035 & 0.328 & 0.071 & 0.463 & 0.088 \\
\hline -11 & 0.531 & 0.025 & 0.409 & 0.084 & 0.307 & 0.092 & 0.413 & 0.079 & 0.538 & 0.080 \\
\hline $1 \overline{2} \mathrm{pl}$ & 0.978 & 0.001 & 0.922 & 0.002 & 1.033 & 0.000 & 1.183 & 0.000 & 1.250 & 0.002 \\
\hline $\mathrm{sec}$ & -0.051 & 0.892 & -0.142 & 0.704 & -0.283 & 0.405 & -0.249 & 0.521 & -0.187 & 0.650 \\
\hline & & 0.339 & -0.406 & 0.228 & -0.419 & 0.199 & -0.514 & 0.174 & -0.431 & 0.279 \\
\hline $\mathrm{adm}$ & 0.807 & 0.143 & 0.895 & 0.123 & 1.208 & 0.015 & 1.145 & 0.025 & 1.233 & 0.035 \\
\hline sfor & 0.311 & 0.609 & 0.684 & 0.265 & 1.130 & 0.023 & 0.594 & 0.254 & 0.738 & 0.221 \\
\hline com & 0.744 & 0.196 & 0.799 & 0.177 & 1.277 & 0.013 & 0.854 & 0.124 & 0.945 & 0.152 \\
\hline rvic & 0.692 & 0.189 & 0.785 & 0.175 & 1.067 & 0.035 & 0.774 & 0.130 & 0.896 & 0.114 \\
\hline ccup & 0.374 & 0.506 & 0.624 & 0.316 & 0.999 & 0.041 & 0.640 & 0.195 & 0.789 & 0.152 \\
\hline & 0.526 & 0.000 & 0.262 & 0.004 & 0.278 & 0.010 & 0.226 & 0.019 & 0.207 & 0.121 \\
\hline & 3.135 & 0.000 & 3.437 & 0.000 & 3.533 & 0.000 & 4.458 & 0.000 & 4.637 & 0.000 \\
\hline
\end{tabular}


Appendix C3. continued

\begin{tabular}{|c|c|c|c|c|c|c|c|c|c|c|}
\hline Bahia, females & $\begin{array}{c}\text { Coef. } \\
\text { q10 }\end{array}$ & $P>|t|$ & $\begin{array}{c}\text { Coef. } \\
\text { q25 }\end{array}$ & $P>|t|$ & $\begin{array}{c}\text { Coef. } \\
\text { q50 }\end{array}$ & $P>|t|$ & $\begin{array}{c}\text { Coef. } \\
\text { q75 }\end{array}$ & $P>|t|$ & $\begin{array}{c}\text { Coef. } \\
\text { q90 }\end{array}$ & $P>|t|$ \\
\hline white & 0.040 & 0.708 & 0.104 & 0.095 & 0.093 & 0.090 & 0.123 & 0.098 & 0.084 & 0.339 \\
\hline union & 148 & 0.251 & & 347 & 277 & .081 & 418 & 005 & 193 & .144 \\
\hline ban & -0.223 & 0.395 & -0.037 & 0.792 & 0.054 & 0.670 & 0.022 & 0.901 & -0.116 & 0.575 \\
\hline tropol & 0.445 & 0.000 & 0.464 & 0.000 & 0.444 & 0.000 & 0.406 & 0.000 & 0.227 & 0.012 \\
\hline ten & -0.209 & 0.083 & -0.036 & 0.637 & -0.078 & 0.239 & -0.039 & 0.549 & -0.050 & 0.547 \\
\hline 21_30 & 0.276 & 0.215 & 0.325 & 0.002 & 0.232 & 0.034 & 0.260 & 0.023 & 0.114 & 0.335 \\
\hline e31_40 & 0.161 & 0.545 & 0.378 & 0.003 & 0.347 & 0.003 & 0.397 & 0.000 & 0.256 & 0.037 \\
\hline e41_50 & 0.477 & 0.037 & 0.520 & 0.000 & 0.359 & 0.002 & 0.296 & 0.022 & 0.296 & 0.061 \\
\hline 51_70 & 173 & 0.600 & 0.260 & 0.074 & 0.257 & 0.100 & 0.436 & 0.049 & 0.399 & 0.075 \\
\hline nu1_2 & 0.170 & 0.168 & 0.132 & 0.111 & 0.148 & 0.036 & 0.142 & 0.092 & 0.168 & 0.069 \\
\hline nu3_6 & 0.101 & 0.536 & 0.200 & 0.059 & 0.143 & 0.120 & 0.258 & 0.035 & 0.465 & 0.000 \\
\hline & 307 & 0.115 & 0.201 & 0.110 & 0.300 & 0.005 & 0.371 & 0.003 & 0.463 & 0.002 \\
\hline $1 \overline{3} p$ & 0.582 & 0.027 & 0.389 & 0.011 & 0.570 & 0.000 & 0.807 & 0.000 & 0.704 & 0.001 \\
\hline 1144 & 0.018 & 0.912 & 0.155 & 0.138 & 0.063 & 0.482 & 0.222 & 0.032 & 0.222 & 0.084 \\
\hline & 0.156 & 0.298 & 0.232 & 0.050 & 0.148 & 0.167 & 0.300 & 0.003 & 0.457 & 0.001 \\
\hline $19 \_11$ & 0.291 & 0.124 & 0.369 & 0.011 & 0.321 & 0.015 & 0.421 & 0.008 & 0.918 & 0.000 \\
\hline$d 1 \overline{2} \mathrm{pl}$ & 0.582 & 0.032 & 0.756 & 0.002 & 0.979 & 0.000 & 1.251 & 0.000 & 1.476 & 0.000 \\
\hline & -0.268 & 0.420 & -0.105 & 0.650 & -0.006 & 0.975 & 0.249 & 0.145 & 0.477 & 0.023 \\
\hline & -0.398 & 0.091 & -0.223 & 0.227 & -0.190 & 0.221 & -0.018 & 0.906 & 0.279 & 0.114 \\
\hline adm & 0.351 & 0.418 & 0.575 & 0.202 & 0.089 & 0.819 & -0.043 & 0.889 & -0.082 & 0.791 \\
\hline & -0.129 & 0.778 & 0.065 & 0.886 & -0.200 & 0.608 & -0.471 & 0.111 & -0.495 & 0.124 \\
\hline acom & 0.104 & 0.822 & 0.299 & 0.505 & -0.113 & 0.762 & -0.268 & 0.343 & -0.275 & 0.344 \\
\hline ervic & 0.154 & 0.709 & 0.292 & 0.505 & -0.053 & 0.884 & -0.134 & 0.621 & -0.149 & 0.599 \\
\hline ccup & 0.084 & 0.841 & 0.228 & 0.611 & -0.096 & 0.798 & -0.203 & 0.451 & -0.073 & 0.794 \\
\hline arteıra & 0.513 & 0.000 & 0.291 & 0.001 & 0.308 & 0.000 & 0.146 & 0.071 & 0.139 & 0.084 \\
\hline cons & 4.297 & 0.000 & 3.966 & 0.000 & 4.604 & 0.000 & 4.757 & 0.000 & 5.045 & 0.000 \\
\hline
\end{tabular}


Appendix C3. continued

\begin{tabular}{|c|c|c|c|c|c|c|c|c|c|c|}
\hline eara, female & $\begin{array}{c}\text { Coef. } \\
\text { q10 }\end{array}$ & $P>|t|$ & $\begin{array}{l}\text { Coef. } \\
\text { q25 }\end{array}$ & $P>|t|$ & $\begin{array}{c}\text { Coef. } \\
\text { q50 }\end{array}$ & $P>|t|$ & $\begin{array}{c}\text { Coef. } \\
\text { q75 }\end{array}$ & $P>|t|$ & $\begin{array}{c}\text { Coef. } \\
\text { q90 }\end{array}$ & $P>|t|$ \\
\hline white & 0,090 & 0,585 & 0,067 & 0,540 & 0,173 & 0,111 & 0,253 & 0,020 & 0,362 & 0,002 \\
\hline union & 0,202 & 0,449 & 0,194 & 0,256 & 0,321 & 0,106 & 0,431 & 0,063 & 0,222 & 0,457 \\
\hline rban & & & & 0,497 & & & & 0,325 & & 40,343 \\
\hline etropol & 0,842 & 0,000 & & 0,000 & 0,500 & 0,000 & 0,436 & 0,002 & 0,40 & 0,005 \\
\hline liveten & $-0,241$ & 0,138 & $-0,221$ & 0,075 & $-0,143$ & 0,233 & $-0,110$ & 0,415 & $-0,017$ & 7,912 \\
\hline ge21_30 & 0,402 & 0,070 & 0,588 & 0,002 & 0,372 & 0,021 & & 0,006 & & 0,004 \\
\hline ye31_40 & & & & 0,009 & 0,508 & 0,006 & & 0,001 & & 0,010 \\
\hline age41_50 & 0,274 & 0,320 & 0,563 & 0,008 & 0,467 & 0,026 & 0,484 & 0,052 & 0,488 & 0,059 \\
\hline age51_70 & 0,365 & 0,253 & 0,361 & 0,166 & 0,337 & 0,156 & 0,625 & 0,026 & 0,6 & 0,050 \\
\hline enu1 2 & 0,234 & 0,379 & 0,067 & 0,770 & $-0,048$ & 0,747 & $-0,020$ & 0,889 & 0,001 & 0,994 \\
\hline tenu3 6 & 0,124 & 0,643 & 0,065 & 0,796 & $-0,038$ & 0,810 & $1-0,0 \mathrm{~s}$ & 0,593 & 0,110 & 0,603 \\
\hline $7-12$ & 0,279 & 0,296 & & 0,453 & $-0,1$ & & & & & 0,850 \\
\hline $11 \overline{3} p$ & 0,391 & 0,258 & 0,122 & 0,687 & $-0,059$ & 0,827 & -0 & 0,583 & 0,29 & 0,496 \\
\hline stud1_4 & $-0,046$ & 0,844 & 0,085 & 0,641 & 0,277 & 0,052 & 0,173 & 0,324 & 0,26 & 0,188 \\
\hline ud5_8 & 0,224 & 0,317 & 0,1 & 0,307 & 0,304 & 0,018 & & 0,027 & & 0,029 \\
\hline stud9 11 & $-0,025$ & 0,941 & 0,086 & 0,690 & 0,378 & 0,058 & 0,580 & 0,008 & 0,599 & 0,027 \\
\hline stud12̄pl & 0,3 & 0,3 & 0,2 & 0,123 & $0, \varepsilon$ & 0,004 & 0,751 & 0,032 & 0 & 0,277 \\
\hline & & & & & & & & & & 0,907 \\
\hline tertsec & $-0,2 ?$ & 0,587 & $-0, \subseteq$ & 0,044 & $-0,78$ & 0,052 & $-0,4$ & 0,33 & $-0,0$ & 0,914 \\
\hline techadm & $-0,0$ & & & 0,08 & & 0,047 & & 0,02 & & 0,029 \\
\hline & $-0,5$ & & 0,6 & 0,173 & 0,7 & 0,175 & 0 & 0,141 & & 0,293 \\
\hline octracom & $-0,4$ & 0,3 & 0,5 & 0,271 & 0,8 & 0,129 & 1,0 & 0,073 & 0,8 & 0,187 \\
\hline ocservic & & & & 0,330 & & 0,144 & & 0,117 & & 0,144 \\
\hline & $-0,3$ & & & 0,164 & 0,7 & 0,156 & & 0,295 & & 0,333 \\
\hline & & & 0,2 & 0,00 & & & & & & 0,422 \\
\hline cons & 3,937 & 0,000 & 4,374 & 0,000 & 4,208 & 0,000 & 4,248 & 0,000 & 3,909 & 0,000 \\
\hline
\end{tabular}


Appendix C4. Quantile regressions including rural areas

\begin{tabular}{|c|c|c|c|c|c|c|c|c|c|c|}
\hline $\mathrm{NE}$, rural & $\begin{array}{c}\text { Coef. } \\
\text { q10 }\end{array}$ & $P>|t|$ & $\begin{array}{c}\text { Coef. } \\
\text { q25 }\end{array}$ & $P>|t|$ & $\begin{array}{c}\text { Coef. } \\
\text { q50 }\end{array}$ & $P>|t|$ & $\begin{array}{c}\text { Coef. } \\
\text { q75 }\end{array}$ & $P>|t|$ & $\begin{array}{c}\text { Coef. } \\
\text { q90 }\end{array}$ & $P>|t|$ \\
\hline female & -0.468 & 0.022 & -0.437 & 0.002 & -0.436 & 0.001 & -0.392 & 0.002 & -0.396 & 0.006 \\
\hline white & 0.188 & 0.164 & 0.055 & 0.525 & 0.025 & 0.707 & 0.111 & 0.213 & 0.208 & 0.083 \\
\hline union & -0.016 & 0.929 & -0.048 & 0.704 & -0.092 & 0.364 & -0.146 & 0.136 & -0.238 & 0.127 \\
\hline metropol & 0.514 & 0.000 & 0.401 & 0.000 & 0.392 & 0.000 & 0.426 & 0.000 & 0.420 & 0.004 \\
\hline vete & 0.012 & 0.932 & -0.074 & 0.387 & -0.045 & 0.543 & 0.018 & 0.832 & 0.041 & 0.684 \\
\hline age21_30 & 0.399 & 0.203 & 0.330 & 0.066 & 0.352 & 0.000 & 0.472 & 0.000 & 0.434 & 0.002 \\
\hline age31_40 & 0.466 & 0.158 & 0.515 & 0.007 & 0.523 & 0.000 & 0.597 & 0.000 & 0.539 & 0.001 \\
\hline ge41_50 & 0.249 & 0.454 & 0.333 & 0.108 & 0.490 & 0.000 & 0.554 & 0.000 & 0.432 & 0.009 \\
\hline age51_70 & 0.385 & 0.245 & 0.335 & 0.122 & 0.373 & 0.006 & 0.559 & 0.000 & 0.402 & 0.023 \\
\hline tenu1_2 & -0.098 & 0.568 & 0.033 & 0.786 & 0.068 & 0.511 & -0.098 & 0.426 & -0.116 & 0.410 \\
\hline 366 & -0.071 & 0.740 & -0.138 & 0.276 & -0.087 & 0.437 & -0.283 & 0.029 & -0.1 & 0.283 \\
\hline tenu7_12 & -0.178 & 0.505 & 0.031 & 0.827 & 0.066 & 0.628 & -0.111 & 0.476 & -0.028 & 0.871 \\
\hline tenu13̄p & -0.065 & 0.783 & -0.168 & 0.275 & -0.119 & 0.350 & -0.363 & 0.019 & -0.175 & 0.501 \\
\hline ud1_4 & 0.093 & 0.563 & 0.013 & 0.906 & 0.212 & 0.014 & 0.270 & 0.002 & 0.226 & 0.015 \\
\hline ud5_8 & 0.224 & 0.245 & 0.151 & 0.259 & 0.363 & 0.002 & 0.479 & 0.000 & 0.326 & 0.017 \\
\hline ud9-11 & 0.208 & 0.373 & 0.264 & 0.118 & 0.329 & 0.075 & 0.207 & 0.400 & 0.491 & 0.222 \\
\hline ud12̄pl & 0.704 & 0.173 & 1.325 & 0.008 & 1.722 & 0.000 & 1.854 & 0.000 & 2.119 & 0.000 \\
\hline $\mathrm{sec}$ & 0.566 & 0.144 & 0.228 & 0.569 & 0.022 & 0.943 & 0.061 & 0.809 & 0.1 & 0.434 \\
\hline sec & 0.475 & 0.194 & 0.115 & 0.738 & -0.097 & 0.753 & -0.229 & 0.404 & -0.066 & 0.819 \\
\hline $\mathrm{adm}$ & 0.090 & 0.821 & 0.195 & 0.602 & 0.505 & 0.104 & 0.690 & 0.005 & 0.500 & 0.049 \\
\hline isfor & -0.231 & 0.595 & -0.019 & 0.961 & 0.272 & 0.375 & 0.143 & 0.579 & 0.027 & 0.925 \\
\hline racom & 0.055 & 0.898 & 0.364 & 0.319 & 0.473 & 0.157 & 0.628 & 0.041 & 0.426 & 0.160 \\
\hline ervic & -0.255 & 0.534 & -0.070 & 0.845 & 0.245 & 0.451 & 0.374 & 0.202 & 0.626 & 0.046 \\
\hline NAoccup & -0.395 & 0.321 & -0.391 & 0.290 & 0.061 & 0.846 & 0.034 & 0.901 & -0.192 & 0.506 \\
\hline carteira & 0.555 & 0.000 & 0.446 & 0.000 & 0.408 & 0.000 & 0.359 & 0.000 & 0.353 & 0.002 \\
\hline cons & 3.697 & 0.000 & 4.334 & 0.000 & 4.436 & 0.000 & 4.743 & 0.000 & 5.008 & 0.000 \\
\hline
\end{tabular}


Appendix C4. continued

\begin{tabular}{|c|c|c|c|c|c|c|c|c|c|c|}
\hline Pernamb, rural & $\begin{array}{c}\text { Coef. } \\
\text { q10 }\end{array}$ & $P>|t|$ & $\begin{array}{c}\text { Coef. } \\
\text { q25 }\end{array}$ & $P>|t|$ & $\begin{array}{c}\text { Coef. } \\
\text { q50 }\end{array}$ & $P>|t|$ & $\begin{array}{c}\text { Coef. } \\
\text { q75 }\end{array}$ & $P>|t|$ & $\begin{array}{c}\text { Coef. } \\
\text { q90 }\end{array}$ & $P>|t|$ \\
\hline emale & -0.533 & 0.266 & -0.473 & 0.272 & -0.372 & 0.321 & -0.507 & 0.164 & -0.972 & 0.021 \\
\hline white & 72 & 0.205 & 0.215 & 0.410 & 0.023 & 0.913 & 0.016 & 941 & 0.118 & 0.634 \\
\hline nion & 416 & 0.388 & 0.256 & 0.526 & -0.371 & 0.283 & -0.185 & 0.518 & -0.430 & 0.212 \\
\hline & 0.535 & 0.224 & 0.719 & 0.061 & 0.664 & 0.087 & 0.774 & 0.054 & 0.973 & 0.031 \\
\hline & -0.595 & 0.101 & -0.449 & 0.131 & -0.229 & 0.249 & -0.062 & 0.751 & -0.159 & 0.502 \\
\hline 1_30 & 752 & 0.171 & 0.922 & 0.043 & 0.304 & 0.392 & 0.453 & 0.171 & 0.876 & 0.022 \\
\hline ge31_40 & 0.314 & 0.564 & 0.421 & 0.374 & 0.124 & 0.742 & 0.381 & 0.317 & 0.722 & 0.056 \\
\hline ye41_50 & 1.252 & 0.048 & 1.274 & 0.027 & 0.623 & 0.222 & 0.829 & 0.097 & 1.243 & 0.009 \\
\hline & 396 & 0.454 & 0.552 & 0.230 & 0.104 & 0.794 & 0.359 & 0.354 & 0.415 & 0.273 \\
\hline & -1.350 & 0.067 & -1.007 & 0.096 & -0.418 & 0.398 & -0.303 & 0.464 & 0.035 & 0.938 \\
\hline & -0.220 & 0.749 & -0.440 & 0.427 & -0.470 & 0.315 & -0.446 & 0.321 & -0.402 & 0.432 \\
\hline & .724 & 0.316 & -0.622 & .255 & -0.041 & 0.936 & -0.138 & 0.740 & 0.006 & 0.990 \\
\hline & -0.334 & 0.656 & -0.423 & 0.524 & -0.231 & 0.646 & -0.538 & 0.259 & -0.150 & 0.781 \\
\hline 4 & 0.249 & 0.472 & 0.272 & 0.416 & 0.110 & 0.651 & 0.067 & 0.765 & -0.033 & 0.893 \\
\hline & 0.584 & 0.397 & 0.470 & 0.466 & -0.407 & 0.477 & -0.060 & 0.901 & 0.359 & 0.494 \\
\hline & 1.117 & 0.345 & 0.567 & 0.585 & -0.001 & 0.999 & -0.278 & 0.728 & -0.381 & 0.637 \\
\hline $\mid \overline{2} \mathrm{pl}$ & 2.662 & 0.005 & 2.319 & 0.005 & 2.278 & 0.007 & 1.826 & 0.028 & 1.081 & 0.201 \\
\hline & -1.709 & 0.172 & -1.134 & 0.258 & 0.288 & 0.694 & 1.091 & 0.121 & 0.805 & 0.307 \\
\hline & -1.902 & 0.140 & -1.333 & 0.205 & 0.357 & 0.630 & 1.120 & 0.124 & 1.340 & 0.086 \\
\hline $\mathrm{adm}$ & 1.821 & 0.057 & 1.422 & 0.064 & 0.280 & 0.630 & 0.070 & 0.904 & -0.035 & 0.958 \\
\hline & 2.497 & 0.033 & 1.782 & 0.070 & 0.033 & 0.965 & -0.973 & 0.175 & -1.346 & 0.095 \\
\hline acom & 2.486 & 0.077 & 1.967 & 0.080 & -0.040 & 0.961 & -0.944 & 0.230 & -1.487 & 0.092 \\
\hline rvic & 3.002 & 0.031 & 2.224 & 0.053 & 0.600 & 0.499 & -0.330 & 0.717 & -0.842 & 0.371 \\
\hline & 2.546 & 0.058 & 1.550 & 0.149 & -0.373 & 0.635 & -1.012 & 0.172 & -1.157 & 0.137 \\
\hline carteira & 0.327 & 0.345 & 0.272 & 0.347 & 0.449 & 0.029 & 0.325 & 0.067 & 0.431 & 0.045 \\
\hline cons & 4.298 & 0.000 & 4.348 & 0.000 & 4.961 & 0.000 & 4.968 & 0.000 & 4.866 & 0.000 \\
\hline
\end{tabular}


Appendix C4. continued

\begin{tabular}{|c|c|c|c|c|c|c|c|c|c|c|}
\hline Bahia, rural & $\begin{array}{c}\text { Coef. } \\
\text { q10 }\end{array}$ & $P>|t|$ & $\begin{array}{c}\text { Coef. } \\
\text { q25 }\end{array}$ & $P>|t|$ & $\begin{array}{c}\text { Coef. } \\
\text { q50 }\end{array}$ & $P>|t|$ & $\begin{array}{c}\text { Coef. } \\
\text { q75 }\end{array}$ & $P>|t|$ & $\begin{array}{c}\text { Coef. } \\
\text { q90 }\end{array}$ & $P>|t|$ \\
\hline female & -0.398 & 0.157 & -0.219 & 0.384 & 0.076 & 0.777 & -0.019 & 0.941 & -0.084 & 0.774 \\
\hline whi & 24 & 539 & 011 & 950 & -0.189 & 0.292 & 05 & 552 & .022 & 0.910 \\
\hline$n$ & -0.234 & 453 & -0.307 & 0.254 & -0.129 & 0.589 & -0.288 & 0.173 & -0.287 & 0.302 \\
\hline & 0.205 & 0.322 & 0.251 & 0.209 & 0.104 & 0.644 & -0.104 & 0.658 & 0.011 & 0.966 \\
\hline live & -0.288 & 0.147 & -0.349 & 0.082 & -0.055 & 0.780 & -0.044 & 0.828 & 0.018 & 0.936 \\
\hline 1_30 & 0.802 & 0.069 & 0.498 & 0.351 & 0.365 & 0.344 & 0.325 & 0.254 & 0.312 & 0.200 \\
\hline age31_40 & 1.318 & 0.002 & 0.864 & 0.081 & 0.461 & 0.164 & 0.405 & 0.117 & 0.699 & 0.006 \\
\hline 41_50 & 1.173 & 0.011 & 1.019 & 0.070 & 0.299 & 0.478 & 0.656 & 0.069 & 0.588 & 0.154 \\
\hline & 330 & 006 & 1.019 & 0.046 & 0.480 & 0.184 & 0.693 & 0.024 & 0.510 & 0.126 \\
\hline nu1_2 & -0.033 & 0.880 & -0.088 & 0.723 & 0.020 & 0.937 & -0.271 & 0.298 & -0.294 & 0.247 \\
\hline nu3_6 & -0.187 & 0.470 & -0.201 & 0.432 & -0.112 & 0.633 & -0.345 & 0.194 & -0.020 & 0.949 \\
\hline & .157 & 638 & -0.286 & 0.400 & 0.002 & 0.995 & -0.205 & 0.497 & -0.205 & 0.495 \\
\hline & -0.280 & 0.419 & -0.221 & 0.512 & 0.009 & 0.981 & -0.145 & 0.734 & 0.137 & 0.728 \\
\hline & -0.185 & 0.393 & 0.030 & 0.887 & 0.236 & 0.250 & 0.441 & 0.027 & 0.300 & 0.150 \\
\hline & 0.180 & 0.455 & 0.550 & 0.037 & 0.348 & 0.151 & 0.693 & 0.003 & 0.683 & 0.017 \\
\hline & 0.967 & 0.153 & 0.459 & 0.501 & 0.698 & 0.316 & 0.592 & 0.445 & 1.230 & 0.116 \\
\hline $1 \overline{2} \mathrm{pl}$ & 2.060 & 0.077 & 1.383 & 0.212 & 0.436 & 0.693 & 2.805 & 0.021 & 2.697 & 0.039 \\
\hline & 0.310 & 0.692 & 0.130 & 0.873 & 0.043 & 0.955 & 0.625 & 0.465 & 0.543 & 0.539 \\
\hline & -0.561 & 0.428 & -0.346 & 0.617 & -0.445 & 0.535 & 0.124 & 0.875 & -0.284 & 0.746 \\
\hline $\mathrm{adm}$ & 0.262 & 0.684 & 0.556 & 0.344 & 0.961 & 0.133 & 0.221 & 0.760 & -0.049 & 0.950 \\
\hline & 0.034 & 0.967 & -0.035 & 0.967 & -0.031 & 0.969 & -0.345 & 0.708 & -0.466 & 0.631 \\
\hline acom & 1.109 & 0.147 & 0.883 & 0.239 & 1.147 & 0.142 & 0.566 & 0.539 & 0.528 & 0.599 \\
\hline ervic & 0.957 & 0.225 & 0.524 & 0.474 & 0.307 & 0.691 & -0.132 & 0.870 & 0.327 & 0.712 \\
\hline sccup & 0.443 & 0.514 & 0.257 & 0.707 & 0.259 & 0.714 & -0.563 & 0.479 & -0.543 & 0.537 \\
\hline carteira & 0.420 & 0.047 & 0.534 & 0.002 & 0.481 & 0.011 & 0.219 & 0.263 & 0.095 & 0.659 \\
\hline cons & 3.699 & 0.000 & 4.199 & 0.000 & 4.592 & 0.000 & 5.001 & 0.000 & 5.156 & 0.000 \\
\hline
\end{tabular}


Appendix C4. continued

Ceara, rural Coef. $P>|t|$ Coef. $P>|t|$ Coef. $P>|t|$ Coef. $P>|t|$ Coef. $P>|t|$

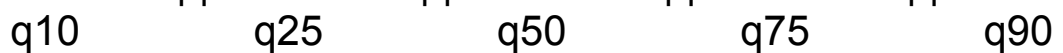

female $\quad 0,057 \quad 0,948-0,1830,825-0,1310,864-0,0650,929-0,2450,740$

$\begin{array}{llllllllllllllllllll}\text { white } & 0,286 & 0,627 & 0,237 & 0,658 & 0,307 & 0,528 & 0,333 & 0,461 & 0,499 & 0,329\end{array}$

union $\quad 0,2460,7780,5550,501-0,1400,835-0,3600,592-0,1940,778$

$\begin{array}{lllllllllllllll}\text { metropol } \quad 0,889 & 0,162 & 0,620 & 0,270 & 0,495 & 0,349 & 0,134 & 0,818 & 0,276 & 0,659\end{array}$

$\begin{array}{llllllllllllllllllll}\text { liveten } & -0,056 & 0,926 & -0,199 & 0,721 & 0,240 & 0,665 & 0,305 & 0,576 & 0,218 & 0,700\end{array}$

$\begin{array}{lllllllllllllllll}\text { age21_30 } & 0,687 & 0,516 & 0,188 & 0,841 & 0,319 & 0,706 & 0,445 & 0,639 & 0,449 & 0,666\end{array}$

$\begin{array}{lllllllllllll}\text { age31_40 } & 1,324 & 0,234 & 0,886 & 0,363 & 0,950 & 0,243 & 0,413 & 0,642 & 0,910 & 0,348\end{array}$

$\begin{array}{llllllllllllllllllllll}\text { age41_50 } & 1,461 & 0,172 & 0,227 & 0,808 & 0,525 & 0,529 & 0,038 & 0,969 & 0,476 & 0,665\end{array}$

age51_70 1,040 0,418 0,181 0,875 0,248 0,803 -0,098 0,927 -0,280 0,812

$\begin{array}{lllllllllllll}\text { tenu1_2 } & 0,128 & 0,848 & 0,661 & 0,312 & 0,636 & 0,283 & 0,846 & 0,169 & 0,596 & 0,290\end{array}$

tenu3_6 $\quad-0,7130,393-0,1230,882-0,0230,976 \quad 0,3360,6610,188 \quad 0,819$

$\begin{array}{llllllllllllllllll}\text { tenu7_12 } & -0,333 & 0,663 & 0,434 & 0,532 & 0,315 & 0,591 & 0,372 & 0,477 & 0,538 & 0,339\end{array}$

$\begin{array}{lllllllllllllllllll}\text { tenu13p } & 0,654 & 0,397 & 0,797 & 0,267 & 0,267 & 0,691 & 0,374 & 0,584 & 0,540 & 0,422\end{array}$

$\begin{array}{llllllllllllllllll}\text { stud1_4 } & 0,937 & 0,115 & 0,345 & 0,531 & 0,124 & 0,796 & -0,153 & 0,768 & -0,151 & 0,781\end{array}$

$\begin{array}{lllllllllllllllllll}\text { stud5_8 } & 1,839 & 0,095 & 1,044 & 0,283 & 0,617 & 0,439 & 0,365 & 0,640 & 0,039 & 0,962\end{array}$

$\begin{array}{lllllllllllllllllllllll}\text { stud9_11 } 2,432 & 0,043 & 1,864 & 0,083 & 1,113 & 0,247 & 0,463 & 0,649 & 0,407 & 0,708\end{array}$

$\begin{array}{llllllllllllllllll}\text { stud12pl } & 1,010 & 0,540 & 0,502 & 0,751 & 1,586 & 0,273 & 1,241 & 0,411 & -0,069 & 0,965\end{array}$

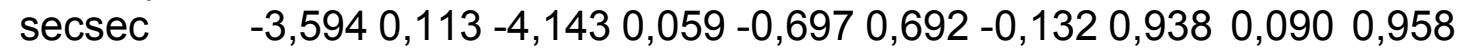

tertsec $\quad-2,2350,182-2,0210,180-1,1460,344-0,6170,611-0,1880,879$

$\begin{array}{lllllllllllllllll}\text { techadm } \quad 1,655 & 0,428 & 1,248 & 0,502 & 0,498 & 0,749 & 1,054 & 0,488 & 1,641 & 0,293\end{array}$

$\begin{array}{llllllllllllllllll}\text { transfor } \quad 4,484 & 0,061 & 4,533 & 0,051 & 0,796 & 0,670 & 1,213 & 0,514 & 0,886 & 0,659\end{array}$

$\begin{array}{lllllllllllllllllllllll}\text { octracom } & 2,798 & 0,180 & 1,932 & 0,311 & 1,375 & 0,368 & 0,721 & 0,624 & 0,459 & 0,760\end{array}$

$\begin{array}{lllllllllllllllllll}\text { ocservic } & 1,579 & 0,336 & 1,580 & 0,303 & 0,738 & 0,563 & 0,284 & 0,819 & 0,099 & 0,936\end{array}$

$\begin{array}{llllllllllllllll}\text { NAoccup } \quad 2,299 & 0,200 & 1,876 & 0,248 & 1,163 & 0,374 & 0,880 & 0,478 & 0,731 & 0,577\end{array}$

$\begin{array}{llllllllllllllllllllll}\text { carteira } & 0,381 & 0,572 & 0,276 & 0,655 & 0,290 & 0,623 & 0,498 & 0,409 & 0,127 & 0,850\end{array}$

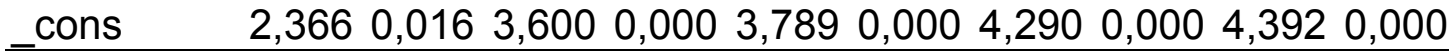


Appendix D. TABLE D2. ADJ-R-SQUARED FROM OLS REGRESSIONS

\begin{tabular}{lccccccccc}
\hline & All & males & females & rural & urban & white & nonwhite & $\begin{array}{c}<\text { yrs } \\
\text { school }\end{array}$ & $\begin{array}{c}>=8 \text { yrs } \\
\text { school }\end{array}$ \\
\hline Bahia & 0.456 & 0.431 & 0.436 & 0.374 & 0.441 & 0.449 & 0.432 & 0.368 & 0.407 \\
Pernambuco & 0.468 & 0.482 & 0.423 & 0.539 & 0.431 & 0.430 & 0.465 & 0.408 & 0.328 \\
Ceara & 0.530 & 0.514 & 0.485 & 0.529 & 0.497 & 0.511 & 0.467 & 0.459 & 0.395 \\
NE & 0.469 & 0.447 & 0.464 & 0.418 & 0.449 & 0.441 & 0.443 & 0.371 & 0.388 \\
Brazil & 0.519 & 0.517 & 0.507 & 0.368 & 0.511 & 0.501 & 0.439 & 0.373 & 0.405 \\
\hline
\end{tabular}


Table F1. One-sided t-tests for equality of coefficients across quantiles, $p$-values for $H_{0}: q A=q B$

\section{Pernambuco}

\section{BAHIA}

\begin{tabular}{l|cccc} 
female \\
\hline qAlqB & q25 & q50 & q75 & q90 \\
\hline q10 & 0.54 & 0.62 & 0.60 & 0.93 \\
q25 & & 0.89 & 0.99 & 0.70 \\
q50 & & & 0.91 & 0,73 \\
q75 & & & & 0.62 \\
\hline
\end{tabular}

\begin{tabular}{l|cccc} 
white \\
\hline qAlqB & q25 & q50 & q75 & q90 \\
\hline q10 & 0.84 & 0.74 & 0.9 & 0.82 \\
q25 & & 0.81 & 0.97 & 0.92 \\
q50 & & & 0.75 & 0,95 \\
q75 & & & & 0.88 \\
\hline
\end{tabular}

\begin{tabular}{l|cccc} 
union \\
\hline qAlqB & q25 & q50 & q75 & q90 \\
\hline q10 & 0.18 & 0.14 & 0.24 & 0.05 \\
q25 & & 0.64 & 0.86 & 0.23 \\
q50 & & & 0.85 & 0,30 \\
q75 & & & & 0.21 \\
\hline
\end{tabular}

\begin{tabular}{l|cccc} 
urban & \multicolumn{1}{l}{} \\
\hline qAlqB & q25 & q50 & q75 & q90 \\
\hline q10 & 0.43 & 0.78 & 0.88 & 0.96 \\
q25 & & 0.55 & 0.24 & 0.41 \\
q50 & & & 0.43 & 0,63 \\
q75 & & & & 0.87 \\
\hline
\end{tabular}

\section{CEARA}

\begin{tabular}{l|cccc} 
female \\
\hline qAlqB & q25 & q50 & q75 & q90 \\
\hline q10 & 0.60 & 0.90 & 0.77 & 0.67 \\
q25 & & 0.38 & 0.33 & 0.35 \\
q50 & & & 0.75 & 0.62 \\
q75 & & & & 0.75
\end{tabular}

female

\begin{tabular}{l|llll}
\hline qAlqB & q25 & q50 & q75 & q90
\end{tabular}

q10

q25

q50

q75

\begin{tabular}{l|cccc} 
white & \multicolumn{1}{l}{} \\
\hline qAlqB & q25 & q50 & q75 & q90 \\
\hline q10 & 0.09 & 0.13 & 0.56 & 0.71 \\
q25 & & 0.87 & 0.30 & 0.36 \\
q50 & & & 0.23 & 0.33 \\
q75 & & & & 0.87 \\
\hline
\end{tabular}

\begin{tabular}{l|cccc} 
union & \multicolumn{1}{l}{} \\
\hline qA1qB & q25 & q50 & q75 & q90 \\
\hline q10 & 0.56 & 0.74 & 0.08 & 0.48 \\
q25 & & 0.80 & 0.07 & 0.68 \\
q50 & & & 0.02 & 0.55 \\
q75 & & & & 0.35
\end{tabular}

\section{urban}

\begin{tabular}{l|cccc}
\hline qAlqB & q25 & q50 & q75 & q90 \\
\hline q10 & 0.27 & 0.20 & 0.18 & 0.23 \\
q25 & & 0.59 & 0.56 & 0.64 \\
q50 & & & 0.87 & 0.90 \\
q75 & & & & 0.99 \\
\hline
\end{tabular}

\begin{tabular}{l|cccc} 
white & \multicolumn{1}{l}{} \\
\hline qAlqB & q25 & q50 & q75 & q90 \\
\hline q10 & 0.68 & 0.15 & 0.36 & 0.62 \\
q25 & & 0.12 & 0.46 & 0.81 \\
q50 & & & 0.58 & 0.46 \\
q75 & & & & 0.69 \\
\hline
\end{tabular}

\begin{tabular}{l|cccc} 
union & \multicolumn{1}{l}{} \\
\hline qAlqB & q25 & q50 & q75 & q90 \\
\hline q10 & 0.54 & 0.69 & 0.71 & 0.18 \\
q25 & & 0.13 & 0.26 & 0.04 \\
q50 & & & 0.96 & 0.10 \\
q75 & & & & 0.10
\end{tabular}

\section{urban}

\begin{tabular}{l|cccc}
\hline qAlqB & q25 & q50 & q75 & q90 \\
\hline q10 & 0.20 & 0.32 & 0.10 & 0.06 \\
q25 & & 0.85 & 0.39 & 0.26 \\
q50 & & & 0.19 & 0.14 \\
q75 & & & & 0.56 \\
\hline
\end{tabular}

\section{NORTH-EAST}

\begin{tabular}{l|cccc} 
female & \multicolumn{1}{l}{} \\
\hline qA1qB & q25 & q50 & q75 & q90 \\
\hline q10 & 0.43 & 0.78 & 0.93 & 0.30 \\
q25 & & 0.57 & 0.37 & 0.60 \\
q50 & & & 0.53 & 0.34 \\
q75 & & & & 0.09 \\
\hline
\end{tabular}

\begin{tabular}{l|cccc} 
white & \multicolumn{1}{l}{} \\
\hline qAlqB & q25 & q50 & q75 & q90 \\
\hline q10 & 0.96 & 0.21 & 0.27 & 0.31 \\
q25 & & 0.07 & 0.18 & 0.24 \\
q50 & & & 0.96 & 0.89 \\
q75 & & & & 0.84 \\
\hline
\end{tabular}

\begin{tabular}{l|cccc} 
union & \multicolumn{1}{l}{} \\
\hline qAlqB & q25 & q50 & q75 & q90 \\
\hline q10 & 0.45 & 0.01 & 0.00 & 0.00 \\
q25 & & 0.00 & 0.00 & 0.00 \\
q50 & & & 0.00 & 0.03 \\
q75 & & & & 0.88 \\
\hline
\end{tabular}

\begin{tabular}{l|cccc}
\multicolumn{2}{l}{ urban } \\
\hline qAlqB & q25 & q50 & q75 & q90 \\
\hline q10 & 0.27 & 0.59 & 0.46 & 0.44 \\
q25 & & 0.51 & 0.91 & 0.94 \\
q50 & & & 0.59 & 0.62 \\
q75 & & & & 0.96 \\
\hline
\end{tabular}




\begin{tabular}{l|cccc}
\hline qAlqB & q25 & q50 & q75 & q90 \\
\hline q10 & 0.75 & 0.51 & 0.05 & 0.14 \\
q25 & & 0.57 & 0.02 & 0.12 \\
q50 & & & 0.01 & 0,19 \\
q75 & & & & 0.59
\end{tabular}

metropol

\begin{tabular}{l|cccc}
\hline qAlqB & q25 & q50 & q75 & q90 \\
\hline q10 & 0.18 & 0.02 & 0.00 & 0.00 \\
q25 & & 0.08 & 0.01 & 0.01 \\
q50 & & & 0.15 & 0.06 \\
q75 & & & & 0.28 \\
\hline
\end{tabular}

metropol

\begin{tabular}{l|cccc}
\hline qAlqB & q25 & q50 & q75 & q90 \\
\hline q10 & 0.90 & 0.86 & 0.18 & 0.15
\end{tabular}

q25

q75 metropol

\begin{tabular}{l|cccc}
\hline qA1qB & q25 & q50 & q75 & q90 \\
\hline q10 & 0.08 & 0.00 & 0.00 & 0.00 \\
q25 & & 0.03 & 0.00 & 0.00 \\
q50 & & & 0.00 & 0.00 \\
q75 & & & & 0.01
\end{tabular}

\section{BAHIA}

liveten

\begin{tabular}{l|llll}
\hline qAlqB & q25 & q50 & q75 & q90 \\
\hline q10 & 0.88 & 1.00 & 0.53 & 0.69 \\
q25 & & 0.84 & 0.30 & 0.49 \\
q50 & & & 0.26 & 0,56 \\
q75 & & & & 0.66 \\
\hline
\end{tabular}

age21_30

\begin{tabular}{l|cccc}
\hline qAlqB & q25 & q50 & q75 & q90 \\
\hline q10 & 0.11 & 0.05 & 0.04 & 0.02 \\
q25 & & 0.10 & 0.12 & 0.01 \\
q50 & & & 0.64 & 0,12 \\
q75 & & & & 0.16 \\
\hline
\end{tabular}

age31_40

\begin{tabular}{l|cccc}
\hline qAlqB & q25 & q50 & q75 & q90 \\
\hline q10 & 0.12 & 0.08 & 0.08 & 0.06 \\
q25 & & 0.37 & 0.40 & 0.26 \\
q50 & & & 0.81 & 0,57 \\
q75 & & & & 0.63 \\
\hline
\end{tabular}

age41_50

\begin{tabular}{l|cccc}
\hline qAlqB & q25 & q50 & q75 & q90 \\
\hline q10 & 0.10 & 0.08 & 0.03 & 0.02 \\
q25 & & 0.54 & 0.13 & 0.06 \\
q50 & & & 0.18 & 0,14 \\
q75 & & & & 0.52 \\
\hline
\end{tabular}

Ceara

liveten

\begin{tabular}{l|llll}
\hline qAlqB & q25 & q50 & q75 & q90 \\
\hline q10
\end{tabular}

q10

q25

q50

q75

age21_30

\begin{tabular}{l|llll}
\hline qAlqB & q25 & q50 & q75 & q90
\end{tabular}

\begin{tabular}{l|lllll}
\hline $\mathrm{q} 10$ & 0.46 & 0.02 & 0.12 & 0.11
\end{tabular}

q25

q50

q75

\begin{tabular}{l|cccc} 
age31_40 & \multicolumn{1}{l}{} \\
\hline qAlqB & q25 & q50 & q75 & q90 \\
\hline q10 & 0.70 & 0.33 & 0.82 & 0.92 \\
q25 & & 0.35 & 0.88 & 0.61 \\
q50 & & & 0.20 & 0.15 \\
q75 & & & & 0.59 \\
\hline
\end{tabular}

\section{Age41_50}

\begin{tabular}{l|cccc}
\hline qAlqB & q25 & q50 & q75 & q90 \\
\hline q10 & 0.41 & 0.07 & 0.37 & 0.46
\end{tabular}

q10

q25

q75

\section{Pernambuco}

\begin{tabular}{l|cccc} 
liveten \\
\hline qAlqB & q25 & q50 & q75 & q90 \\
\hline q10 & 0.94 & 0.83 & 0.47 & 0.72 \\
q25 & & 0.84 & 0.47 & 0.76 \\
q50 & & & 0.43 & 0.84 \\
q75 & & & & 0.69 \\
\hline
\end{tabular}

\begin{tabular}{l|cccc} 
age21_30 & \multicolumn{1}{l}{} \\
\hline qAlqB & q25 & q50 & q75 & q90 \\
\hline q10 & 0.13 & 0.05 & 0.02 & 0.04 \\
q25 & & 0.34 & 0.10 & 0.33 \\
q50 & & & 0.25 & 0.77 \\
q75 & & & & 0.55 \\
\hline
\end{tabular}

\begin{tabular}{l|cccc} 
age31_40 & \multicolumn{1}{l}{} \\
\hline qAlqB & q25 & q50 & q75 & q90 \\
\hline q10 & 0.35 & 0.21 & 0.11 & 0.53 \\
q25 & & 0.53 & 0.26 & 0.88 \\
q50 & & & 0.37 & 0.53 \\
q75 & & & & 0.12 \\
\hline
\end{tabular}

\begin{tabular}{l|cccc} 
age41_50 & \multicolumn{1}{l}{} \\
\hline qAlqB & q25 & q50 & q75 & q90 \\
\hline q10 & 0.23 & 0.23 & 0.19 & 0.32 \\
q25 & & 0.85 & 0.59 & 0.93 \\
q50 & & & 0.61 & 0.97 \\
q75 & & & & 0.62 \\
\hline
\end{tabular}

\section{NORTH-EAST}

liveten

\begin{tabular}{l|cccc}
\hline qAlqB & q25 & q50 & q75 & q90 \\
\hline q10 & 0.60 & 0.65 & 0.96 & 0.34 \\
q25 & & 0.99 & 0.59 & 0.11 \\
q50 & & & 0.51 & 0.07 \\
q75 & & & & 0.12 \\
\hline
\end{tabular}

age21_30

\begin{tabular}{l|cccc}
\hline qAlqB & q25 & q50 & q75 & q90 \\
\hline q10 & 0.10 & 0.03 & 0.04 & 0.02 \\
q25 & & 0.11 & 0.21 & 0.07 \\
q50 & & & 0.96 & 0.35 \\
q75 & & & & 0.27
\end{tabular}

\begin{tabular}{l|cccc}
\multicolumn{2}{l}{ age31_40 } \\
\hline qAlqB & q25 & q50 & q75 & q90 \\
\hline q10 & 0.39 & 0.47 & 0.69 & 0.46 \\
q25 & & 0.95 & 0.55 & 0.90 \\
q50 & & & 0.45 & 0.83 \\
q75 & & & & 0.43 \\
\hline
\end{tabular}

age41_50

\begin{tabular}{l|cccc}
\hline qAlqB & q25 & q50 & q75 & q90 \\
\hline q10 & 0.34 & 0.26 & 0.43 & 0.21 \\
q25 & & 0.54 & 0.93 & 0.38 \\
q50 & & & 0.59 & 0.56 \\
q75 & & & & 0.23
\end{tabular}


age51_70

\begin{tabular}{l|cccc}
\hline qAlqB & q25 & q50 & q75 & q90 \\
\hline q10 & 0.19 & 0.31 & 0.26 & 0.22 \\
q25 & & 0.53 & 0.87 & 0.84 \\
q50 & & & 0.71 & 0,51 \\
q75 & & & & 0.66 \\
\hline
\end{tabular}

\section{Bahia}

tenu1_2

\begin{tabular}{l|cccc}
\hline qAlqB & q25 & q50 & q75 & q90 \\
\hline q10 & 0.39 & 0.99 & 0.76 & 0.84 \\
q25 & & 0.26 & 0.22 & 0.65 \\
q50 & & & 0.62 & 0,74 \\
q75 & & & & 0.36 \\
\hline
\end{tabular}

tenu3_6

\begin{tabular}{l|cccc}
\hline qAlqB & q25 & q50 & q75 & q90 \\
\hline q10 & 0.22 & 0.30 & 0.16 & 0.13 \\
q25 & & 0.96 & 0.51 & 0.36 \\
q50 & & & 0.49 & 0,39 \\
q75 & & & & 0.67 \\
\hline
\end{tabular}

tenu7_12

\begin{tabular}{l|llll}
\hline qAlqB & q25 & q50 & q75 & q90 \\
\hline q10 & 0.40 & 0.26 & 0.52 & 0.32 \\
q25 & & 0.46 & 0.95 & 0.62 \\
q50 & & & 0.49 & 0,99 \\
q75 & & & & 0.50 \\
\hline
\end{tabular}

tenu13p

\begin{tabular}{l|cccc}
\hline qAlqB & q25 & q50 & q75 & q90 \\
\hline q10 & 0.14 & 0.25 & 0.18 & 0.07 \\
q25 & & 0.86 & 0.83 & 0.35 \\
q50 & & & 0.65 & 0,21 \\
q75 & & & & 0.29 \\
\hline
\end{tabular}

Age51_70

\begin{tabular}{l|cccc}
\hline qAlqB & q25 & q50 & q75 & q90 \\
\hline q10 & 0.28 & 0.08 & 0.41 & 0.86 \\
q25 & & 0.28 & 0.92 & 0.46 \\
q50 & & & 0.19 & 0.08 \\
q75 & & & & 0.39 \\
\hline
\end{tabular}

age51_70

\begin{tabular}{l|cccc}
\hline qAlqB & q25 & q50 & q75 & q90 \\
\hline q10 & 0.08 & 0.11 & 0.12 & 0.45 \\
q25 & & 0.89 & 0.99 & 0.37 \\
q50 & & & 0.87 & 0.37 \\
q75 & & & & 0.26 \\
\hline
\end{tabular}

age51_70

\begin{tabular}{l|cccc}
\hline qAlqB & q25 & q50 & q75 & q90 \\
\hline q10 & 0.82 & 0.85 & 0.66 & 0.88 \\
q25 & & 0.98 & 0.27 & 0.63 \\
q50 & & & 0.15 & 0.58 \\
q75 & & & & 0.62 \\
\hline
\end{tabular}

\section{Pernambuco}

tenu1_2 \begin{tabular}{l|llll}
\hline qAlqB & q25 & q50 & q75 & q90 \\
\hline q10
\end{tabular}

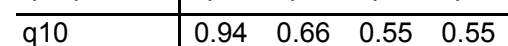
q25 q50 $\mathrm{q} 75$

\begin{tabular}{l|cccc} 
tenu3_6 & \multicolumn{1}{l}{} \\
\hline qAlqB & q25 & q50 & q75 & q90 \\
\hline q10 & 0.96 & 0.60 & 0.91 & 0.78 \\
q25 & & 0.28 & 0.80 & 0.66 \\
q50 & & & 0.50 & 0.76 \\
q75 & & & & 0.74 \\
\hline
\end{tabular}

tenu7_12

\begin{tabular}{l|llll}
\hline qAlqB & q25 & q50 & q75 & q90
\end{tabular}
\begin{tabular}{l|llll}
\hline$q 10$ & 0.71 & 0.49 & 0.49 & 0.24
\end{tabular} q25 q50 q75

\begin{tabular}{l|l}
975 & 0.31 \\
\hline
\end{tabular}

$\begin{array}{lll}0.45 & 0.36 & 0.40\end{array}$ $\begin{array}{ll}0.68 & 0.71\end{array}$

0.95

\begin{tabular}{l|cccc} 
tenu13p & \multicolumn{5}{l}{} \\
\hline qAlqB & q25 & q50 & q75 & q90 \\
\hline q10 & 0.79 & 0.73 & 0.89 & 0.54 \\
q25 & & 0.33 & 0.59 & 0.34 \\
q50 & & & 0.77 & 0.62 \\
q75 & & & & 0.45 \\
\hline
\end{tabular}

tenu1_2

\begin{tabular}{l|cccc}
\hline qAlqB & q25 & q50 & q75 & q90 \\
\hline q10 & 0.42 & 0.60 & 0.84 & 0.61 \\
q25 & & 0.07 & 0.65 & 0.32 \\
q50 & & & 0.32 & 0.80 \\
q75 & & & & 0.37 \\
\hline
\end{tabular}

\section{tenu3_6}

\begin{tabular}{l|llll}
\hline qAlqB & q25 & q50 & q75 & q90 \\
\hline q10
\end{tabular}

q10

q25

q50

q75

\begin{tabular}{l|cccc} 
tenu7_12 & \multicolumn{1}{l}{} \\
\hline qAlqB & q25 & q50 & q75 & q90 \\
\hline q10 & 0.57 & 0.97 & 0.85 & 0.89 \\
q25 & & 0.40 & 0.75 & 0.59 \\
q50 & & & 0.70 & 0.89 \\
q75 & & & & 0.69
\end{tabular}

\section{tenu13p}

\begin{tabular}{l|cccc}
\hline qAlqB & q25 & q50 & q75 & q90 \\
\hline q10 & 0.66 & 0.23 & 0.17 & 0.75
\end{tabular}

q25

q50

q75

\section{NORTH-EAST}

tenu1_2

\begin{tabular}{l|cccc}
\hline qAlqB & q25 & q50 & q75 & q90 \\
\hline q10 & 0.88 & 0.41 & 0.42 & 0.47 \\
q25 & & 0.19 & 0.27 & 0.36 \\
q50 & & & 0.89 & 0.95 \\
q75 & & & & 0.97 \\
\hline
\end{tabular}

\section{tenu3_6}

\begin{tabular}{l|cccc}
\hline qAlqB & q25 & q50 & q75 & q90 \\
\hline q10 & 0.65 & 0.93 & 0.59 & 0.31 \\
q25 & & 0.58 & 0.77 & 0.31 \\
q50 & & & 0.35 & 0.12 \\
q75 & & & & 0.32 \\
\hline
\end{tabular}

tenu7_12

\begin{tabular}{l|cccc}
\hline qAlqB & q25 & q50 & q75 & q90 \\
\hline q10 & 0.75 & 0.53 & 0.47 & 0.34 \\
q25 & & 0.58 & 0.50 & 0.36 \\
q50 & & & 0.76 & 0.52 \\
q75 & & & & 0.65
\end{tabular}

\begin{tabular}{l|cccc} 
tenu13p \\
\hline qAlqB & q25 & q50 & q75 & q90 \\
\hline q10 & 0.80 & 0.57 & 0.28 & 0.17 \\
q25 & & 0.23 & 0.11 & 0.05 \\
q50 & & & 0.33 & 0.18 \\
q75 & & & & 0.49 \\
\hline
\end{tabular}




\begin{tabular}{l|cccc}
\hline qAlqB & q25 & q50 & q75 & q90 \\
\hline q10 & 0.47 & 0.37 & 0.05 & 0.22 \\
q25 & & 0.65 & 0.05 & 0.35 \\
q50 & & & 0.03 & 0,42 \\
q75 & & & & 0.46
\end{tabular}

stud1_4

\begin{tabular}{l|cccc}
\hline qAlqB & q25 & q50 & q75 & q90 \\
\hline q10 & 0.36 & 0.25 & 0.29 & 0.10
\end{tabular}

q25

q75 stud1_4

\begin{tabular}{l|cccc}
\hline qAlqB & q25 & q50 & q75 & q90 \\
\hline q10 & 0.57 & 0.93 & 0.83 & 0.10
\end{tabular}

$\begin{array}{lll}0.84 & 0.82 & 0.38\end{array}$

$0.93 \quad 0.40$

0.31 $\begin{array}{lll}0.57 & 0.80 & 0.17\end{array}$

$\begin{array}{ll}0.83 & 0.04\end{array}$

0.04

stud1_4

\begin{tabular}{l|cccc}
\hline qAlqB & q25 & q50 & q75 & q90 \\
\hline q10 & 0.35 & 0.18 & 0.01 & 0.01 \\
q25 & & 0.37 & 0.01 & 0.02 \\
q50 & & & 0.02 & 0.04 \\
q75 & & & & 0.65
\end{tabular}

\section{Bahia}

stud5_8

\begin{tabular}{l|cccc}
\hline qAlqB & q25 & q50 & q75 & q90 \\
\hline q10 & 0.68 & 0.31 & 0.09 & 0.15 \\
q25 & & 0.27 & 0.06 & 0.14 \\
q50 & & & 0.19 & 0,31 \\
q75 & & & & 0.94 \\
\hline
\end{tabular}

stud9_11

\begin{tabular}{l|cccc}
\hline qAlqB & q25 & q50 & q75 & q90 \\
\hline q10 & 0.43 & 0.70 & 0.08 & 0.24 \\
q25 & & 0.09 & 0.00 & 0.04 \\
q50 & & & 0.02 & 0,21 \\
q75 & & & & 0.53 \\
\hline
\end{tabular}

\begin{tabular}{l|cccc}
\multicolumn{2}{l}{ stud12pl } \\
\hline qAlqB & q25 & q50 & q75 & q90 \\
\hline q10 & 0.93 & 0.24 & 0.02 & 0.10 \\
q25 & & 0.08 & 0.01 & 0.05 \\
q50 & & & 0.03 & 0,30 \\
q75 & & & & 0.53 \\
\hline
\end{tabular}

rrr

\begin{tabular}{l|cccc}
\hline qAlqB & q25 & q50 & q75 & q90 \\
\hline q10 & 0.98 & 0.83 & 0.37 & 0.60 \\
q25 & & 0.77 & 0.23 & 0.53 \\
q50 & & & 0.24 & 0,61 \\
q75 & & & & 0.76
\end{tabular}

secsec

\section{Ceara}

stud5_8

\begin{tabular}{l|llll}
\hline qAlqB & q25 & q50 & q75 & q90
\end{tabular}

\begin{tabular}{l|llll}
\hline q10 & 0.63 & 0.86 & 0.84 & 0.54
\end{tabular}

q25

q50

$\mathrm{q} 75$

stud9_11

\begin{tabular}{l|llll}
\hline qAlqB & q25 & q50 & q75 & q90 \\
\hline q10 & 0.90 & 0.11 & 0.04 & 0.02
\end{tabular}

\begin{tabular}{l|lllll}
\hline $\mathrm{q} 10$ & 0.90 & 0.11 & 0.04 & 0.02
\end{tabular}

q25

q50

q75

\section{stud12pl}

\begin{tabular}{l|llll}
\hline qAlqB & q25 & q50 & q75 & q90 \\
\hline
\end{tabular}

\begin{tabular}{l|lllll}
\hline $\mathrm{q} 10$ & 0.75 & 0.30 & 0.14 & 0.04
\end{tabular}

q25

q50

$\mathrm{q} 75$

\begin{tabular}{l|cccc} 
Rrr \\
\hline qAlqB & q25 & q50 & q75 & q90 \\
\hline q10 & 0.98 & 0.88 & 0.33 & 0.44 \\
q25 & & 0.84 & 0.29 & 0.40 \\
q50 & & & 0.21 & 0.42 \\
q75 & & & & 0.97 \\
\hline
\end{tabular}

Secsec

\section{Pernambuco}

stud5_8

\begin{tabular}{|c|c|c|c|c|c|c|c|c|c|}
\hline qAlqB & q25 & q50 & q75 & q90 & qAlqB & q25 & q50 & $q 75$ & q90 \\
\hline$q 10$ & 0.99 & 0.56 & 0.82 & 0.13 & $q 10$ & 0.98 & 0.57 & 0.07 & 0.04 \\
\hline q25 & & 0.46 & 0.81 & 0.11 & q25 & & 0.34 & 0.01 & 0.01 \\
\hline q50 & & & 0.67 & 0.01 & q50 & & & 0.02 & 0.02 \\
\hline q75 & & & & 0.02 & q75 & & & & 0.35 \\
\hline
\end{tabular}

stud9_11

\begin{tabular}{|c|c|c|c|c|c|c|c|c|c|}
\hline qAlqB & q25 & q50 & q75 & q90 & qAlqB & q25 & q50 & q75 & q90 \\
\hline q10 & 0.28 & 0.68 & 0.93 & 0.06 & q10 & 0.97 & 0.13 & 0.00 & 0.00 \\
\hline q25 & & 0.52 & 0.43 & 0.20 & q25 & & 0.02 & 0.00 & 0.00 \\
\hline q50 & & & 0.68 & 0.05 & q50 & & & 0.00 & 0.01 \\
\hline q75 & & & & 0.01 & q75 & & & & 0.81 \\
\hline
\end{tabular}

stud12pl

\begin{tabular}{l|cccc}
\hline qAlqB & q25 & q50 & q75 & q90 \\
\hline q10 & 0.08 & 0.03 & 0.13 & 0.04
\end{tabular}

q25

q50

q75

$\begin{array}{llll}0.49 & 0.96 & 0.19\end{array}$

$0.41 \quad 0.36$

\begin{tabular}{l}
0.36 \\
0.13 \\
\hline
\end{tabular}

\begin{tabular}{l|cccc} 
rrr & \multicolumn{3}{l}{} \\
\hline qAlqB & q25 & q50 & q75 & q90 \\
\hline q10 & 0.17 & 0.21 & 0.21 & 0.05 \\
q25 & & 0.85 & 0.77 & 0.26 \\
q50 & & & 0.84 & 0.17 \\
q75 & & & & 0.19 \\
\hline
\end{tabular}

secsec 


\begin{tabular}{|c|c|c|c|c|c|c|c|c|c|c|c|c|c|c|c|c|c|c|c|}
\hline qAlqB & q25 & q50 & q75 & q90 & qAlqB & q25 & q50 & q75 & q90 & qAlqB & q25 & q50 & q75 & q90 & qAlqB & q25 & q50 & q75 & q90 \\
\hline q10 & 0.85 & 0.62 & 0.30 & 0.34 & q10 & 0.93 & 0.61 & 0.93 & 0.97 & $\mathrm{q} 10$ & 0.11 & 0.34 & 0.51 & 0.49 & $\mathrm{q} 10$ & 0.01 & 0.00 & 0.01 & 0.03 \\
\hline q25 & & 0.57 & 0.20 & 0.28 & q25 & & 0.14 & 0.25 & 0.87 & q25 & & 0.35 & 0.28 & 0.51 & q25 & & 0.32 & 0.60 & 0.76 \\
\hline q50 & & & 0.30 & 0,47 & q50 & & & 0.99 & 0.49 & q50 & & & 0.61 & 0.91 & q50 & & & 0.57 & 0.60 \\
\hline q75 & & & & 0.94 & q75 & & & & 0.45 & q75 & & & & 0.83 & q75 & & & & 0.82 \\
\hline
\end{tabular}

\section{Bahia}

\begin{tabular}{l|cccc}
\multicolumn{1}{l}{ tertsec } \\
\hline qAlqB & q25 & q50 & q75 & q90 \\
\hline q10 & 0.54 & 0.27 & 0.09 & 0.11 \\
q25 & & 0.27 & 0.05 & 0.11 \\
q50 & & & 0.23 & 0,37 \\
q75 & & & & 0.98 \\
\hline \multicolumn{5}{l}{ techadm } \\
\hline qAlqB & q25 & q50 & q75 & q90 \\
\hline q10 & 0.72 & 0.66 & 0.50 & 0.67 \\
q25 & & 0.23 & 0.19 & 0.85 \\
q50 & & & 0.67 & 0,28 \\
q75 & & & & 0.08 \\
\hline
\end{tabular}

\begin{tabular}{|c|c|c|c|c|}
\hline qAlqB & q25 & q50 & q75 & q90 \\
\hline q10 & 0.69 & 0.40 & 0.31 & 0.49 \\
\hline q25 & & 0.41 & 0.37 & 0.63 \\
\hline q50 & & & 0.75 & 0,92 \\
\hline q75 & & & & 0.66 \\
\hline
\end{tabular}

octracom

\begin{tabular}{l|cccc}
\hline qAlqB & q25 & q50 & q75 & q90 \\
\hline q10 & 0.78 & 0.98 & 0.86 & 0.38 \\
q25 & & 0.69 & 0.93 & 0.38 \\
q50 & & & 0.75 & 0,13 \\
q75 & & & & 0.15 \\
\hline
\end{tabular}

ocservic

\begin{tabular}{l|llll}
\hline qAlqB & q25 & q50 & q75 & q90 \\
\hline
\end{tabular}

\begin{tabular}{l|cccc}
\multicolumn{5}{c}{ Ceara } \\
Tertsec & & & & \\
\hline qAlqB & q25 & q50 & q75 & q90 \\
\hline q10 & 0.98 & 0.40 & 0.34 & 0.75 \\
q25 & & 0.03 & 0.04 & 0.55 \\
q50 & & & 0.71 & 0.48 \\
q75 & & & & 0.27 \\
\hline \multicolumn{7}{l}{ Techadm } & & & & \\
\hline qA1qB & q25 & q50 & q75 & q90 \\
\hline q10 & 0.79 & 0.28 & 0.46 & 0.85 \\
q25 & & 0.06 & 0.33 & 0.99 \\
q50 & & & 0.46 & 0.23 \\
q75 & & & & 0.33 \\
\hline
\end{tabular}

tertsec

qAlqB

\begin{tabular}{l|llll}
\hline $\mathrm{qA} q \mathrm{~B}$ & $\mathrm{q} 25$ & $\mathrm{q} 50$ & $\mathrm{q} 75$ & $\mathrm{q} 90$ \\
\hline $\mathrm{q} 10$ & 0.10 & 0.36 & 0.59 & 0.61
\end{tabular}

q25

q50

q75

\begin{tabular}{l|cccc} 
techadm & \multicolumn{5}{l}{} \\
\hline qAlqB & q25 & q50 & q75 & q90 \\
\hline q10 & 0.51 & 0.90 & 0.99 & 0.67 \\
q25 & & 0.36 & 0.32 & 0.90 \\
q50 & & & 0.78 & 0.58 \\
q75 & & & & 0.37
\end{tabular}

\begin{tabular}{|c|c|c|c|c|}
\hline qAlqB & q25 & $q 50$ & $q 75$ & q90 \\
\hline$q 10$ & 0.46 & 0.26 & 0.35 & 0.57 \\
\hline q25 & & 0.28 & 0.51 & 0.94 \\
\hline q50 & & & 0.76 & 0.51 \\
\hline q75 & & & & 0.54 \\
\hline
\end{tabular}

\section{Octracom}

\begin{tabular}{l|llll}
\hline qAlqB & q25 & q50 & q75 & q90 \\
\hline q10 & 0.69 & 0.30 & 0.47 & 0.96
\end{tabular}

q10

q25

q50

q75

ocservic

\begin{tabular}{l|llll}
\hline qAlqB & q25 & q50 & q75 & q90 \\
\hline
\end{tabular}

\begin{tabular}{l|cccc} 
trans & \multicolumn{5}{l}{} \\
\hline qAlqB & $\mathrm{q} 25$ & $\mathrm{q} 50$ & $\mathrm{q} 75$ & $\mathrm{q} 90$ \\
\hline $\mathrm{q} 10$ & 0.34 & 0.81 & 0.86 & 0.99 \\
$\mathrm{q} 25$ & & 0.22 & 0.10 & 0.27 \\
$\mathrm{q} 50$ & & & 0.36 & 0.69 \\
$\mathrm{q} 75$ & & & & 0.77
\end{tabular}

\begin{tabular}{l|cccc}
\multicolumn{2}{l}{ octracom } \\
\hline qAlqB & q25 & q50 & q75 & q90 \\
\hline q10 & 0.44 & 0.90 & 0.97 & 0.90 \\
q25 & & 0.27 & 0.31 & 0.50 \\
q50 & & & 0.87 & 0.97 \\
q75 & & & & 0.85 \\
\hline
\end{tabular}

ocservic

\begin{tabular}{l|llll}
\hline qAlqB & q25 & q50 & q75 & q90
\end{tabular}

\section{North-East}

\begin{tabular}{|c|c|c|c|c|}
\hline qAlqB & q25 & q50 & $q 75$ & q90 \\
\hline$q 10$ & 0.04 & 0.05 & 0.18 & 0.38 \\
\hline q25 & & 0.91 & 0.58 & 0.41 \\
\hline q50 & & & 0.21 & 0.21 \\
\hline q75 & & & & 0.54 \\
\hline \multicolumn{5}{|c|}{ techadm } \\
\hline qAlqB & $q 25$ & q50 & $q 75$ & $q 90$ \\
\hline q10 & 0.91 & 0.56 & 0.53 & 0.91 \\
\hline q25 & & 0.28 & 0.33 & 0.80 \\
\hline q50 & & & 0.86 & 0.53 \\
\hline q75 & & & & 0.35 \\
\hline
\end{tabular}

\begin{tabular}{l|cccc} 
trans \\
\hline qAlqB & q25 & q50 & q75 & q90 \\
\hline q10 & 0.60 & 0.76 & 0.77 & 0.71 \\
q25 & & 0.81 & 0.32 & 0.32 \\
q50 & & & 0.20 & 0.28 \\
q75 & & & & 0.82 \\
\hline
\end{tabular}

\begin{tabular}{l|cccc} 
octracom & \multicolumn{5}{l}{} \\
\hline qAlqB & q25 & q50 & q75 & q90 \\
\hline q10 & 0.57 & 0.85 & 0.90 & 0.74 \\
q25 & & 0.63 & 0.41 & 0.91 \\
q50 & & & 0.51 & 0.77 \\
q75 & & & & 0.35 \\
\hline
\end{tabular}

ocservic

\begin{tabular}{l|llll}
\hline qAlqB & q25 & q50 & q75 & q90 \\
\hline
\end{tabular} 


\begin{tabular}{|c|c|c|c|c|c|c|c|c|c|c|c|c|c|c|c|c|c|c|c|}
\hline q10 & 0.53 & 0.21 & 0.22 & 0.34 & q10 & 0.44 & 0.11 & 0.20 & 0.54 & q10 & 0.43 & 0.80 & 0.64 & 0.64 & q10 & 0.57 & 0.17 & 0.07 & 0.05 \\
\hline q25 & & 0.24 & 0.31 & 0.55 & q25 & & 0.04 & 0.19 & 0.92 & q25 & & 0.06 & 0.07 & 0.12 & q25 & & 0.13 & 0.05 & 0.04 \\
\hline q50 & & & 0.99 & 0,74 & q50 & & & 0.62 & 0.20 & q50 & & & 0.57 & 0.62 & q50 & & & 0.25 & 0.16 \\
\hline q75 & & & & 0.67 & q75 & & & & 0.21 & q75 & & & & 0.93 & q75 & & & & 0.54 \\
\hline
\end{tabular}

\begin{tabular}{l|cccc} 
Naoccup \\
\begin{tabular}{l|cccc} 
qAlqB & q25 & q50 & q75 & q90 \\
\hline q10 & 0.60 & 0.39 & 0.32 & 0.58 \\
q25 & & 0.46 & 0.39 & 0.83 \\
q50 & & & 0.77 & 0,69 \\
q75 & & & & 0.46 \\
\hline
\end{tabular}
\end{tabular}

\begin{tabular}{l|cccc} 
Naoccup & Ceara \\
\hline qAlqB & q25 & q50 & q75 & q90 \\
\hline q10 & 0.40 & 0.12 & 0.20 & 0.39 \\
q25 & & 0.07 & 0.22 & 0.67 \\
q50 & & & 0.60 & 0.38 \\
q75 & & & & 0.50 \\
\hline
\end{tabular}

Pernambuco
\begin{tabular}{l|cccc} 
Naoccup & \\
\hline qAlqB & q25 & q50 & q75 & q90 \\
\hline q10 & 0.33 & 0.71 & 0.91 & 0.94 \\
q25 & & 0.32 & 0.14 & 0.34 \\
q50 & & & 0.32 & 0.69 \\
q75 & & & & 0.72 \\
\hline
\end{tabular}

Naoccup
\begin{tabular}{l|cccc} 
NA1qB & q25 & q50 & q75 & q90 \\
\hline q19B & 0.84 & 0.48 & 0.24 & 0.24 \\
q25 & & 0.36 & 0.13 & 0.16 \\
q50 & & & 0.27 & 0.35 \\
q75 & & & & 0.88 \\
\hline
\end{tabular}


4. FIGURE 1A. INCOME DISTRIBUTION
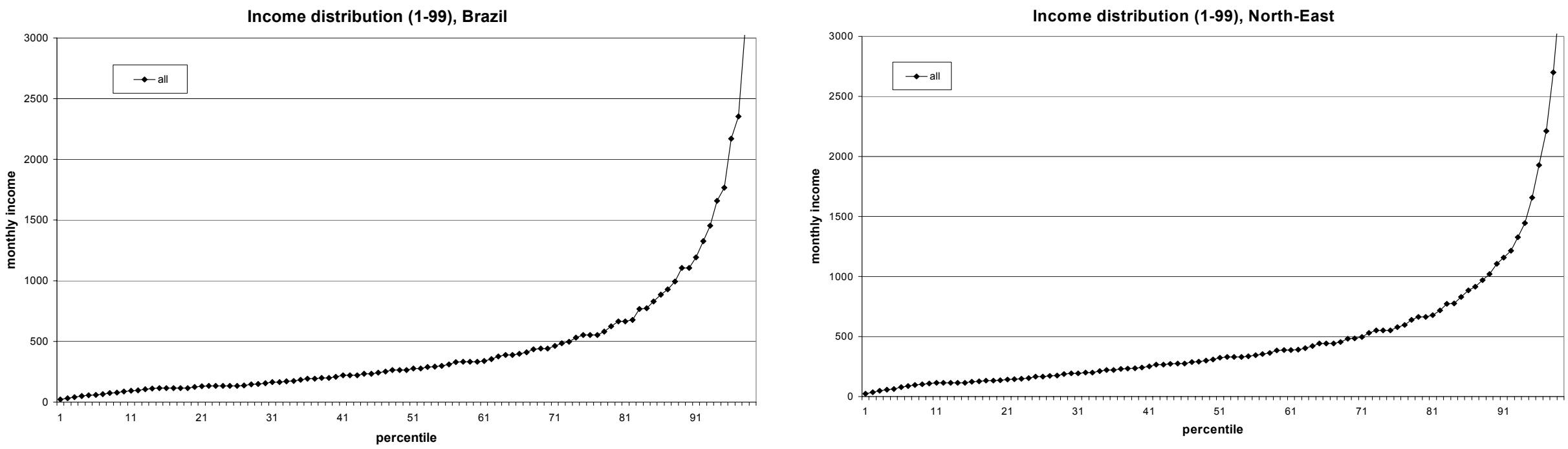

66 
Income distribution (1-99), Bahia

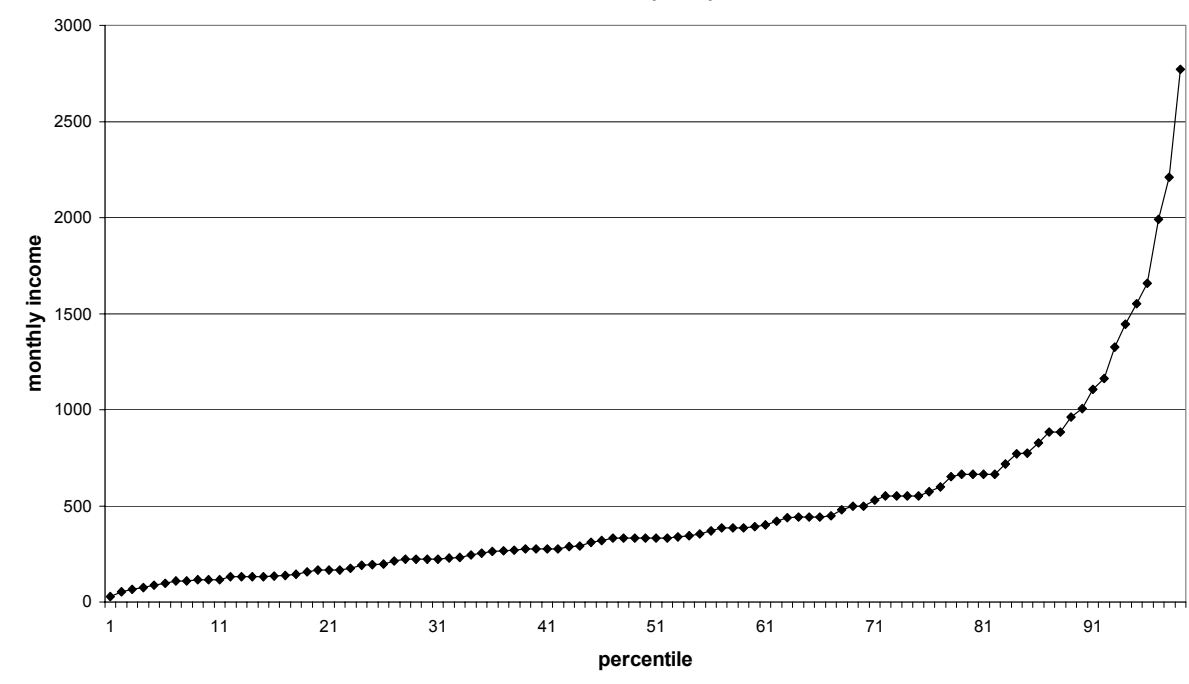

Income distribution (1-99), Pernambuco

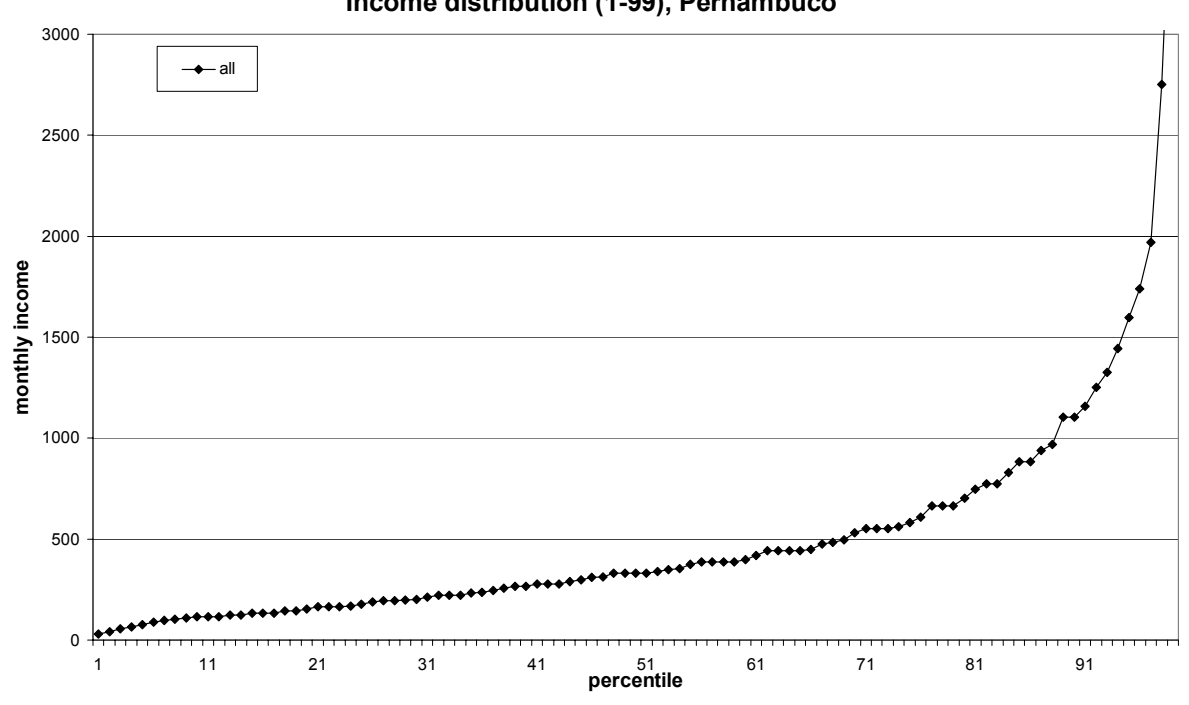




\section{FIGURE 1A, CONTINUED}

Income distribution (1-99), Ceara

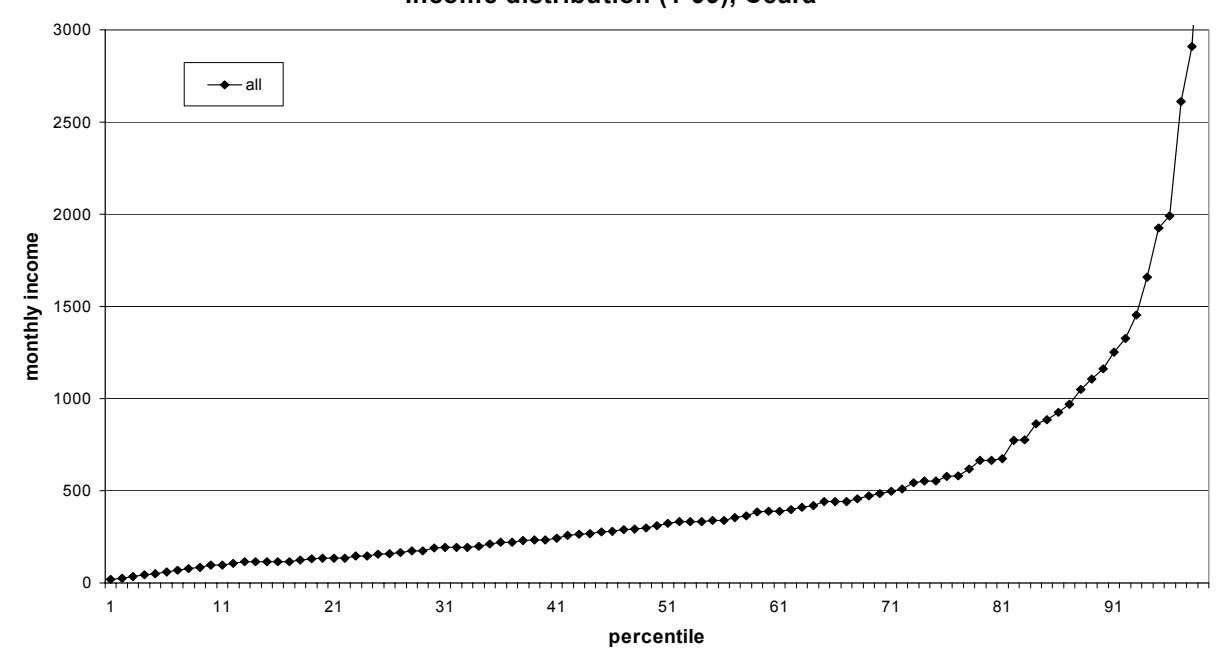


Figure 2A. Income distribution, tenure groups

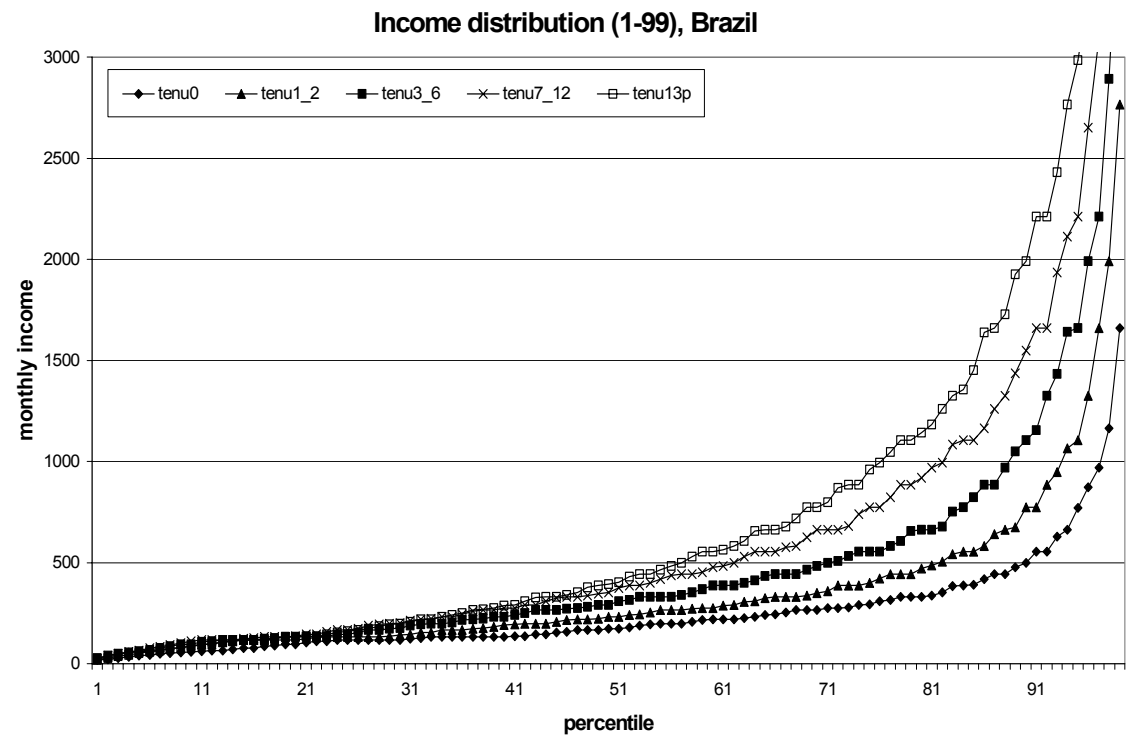

Income distribution (1-99), Bahia

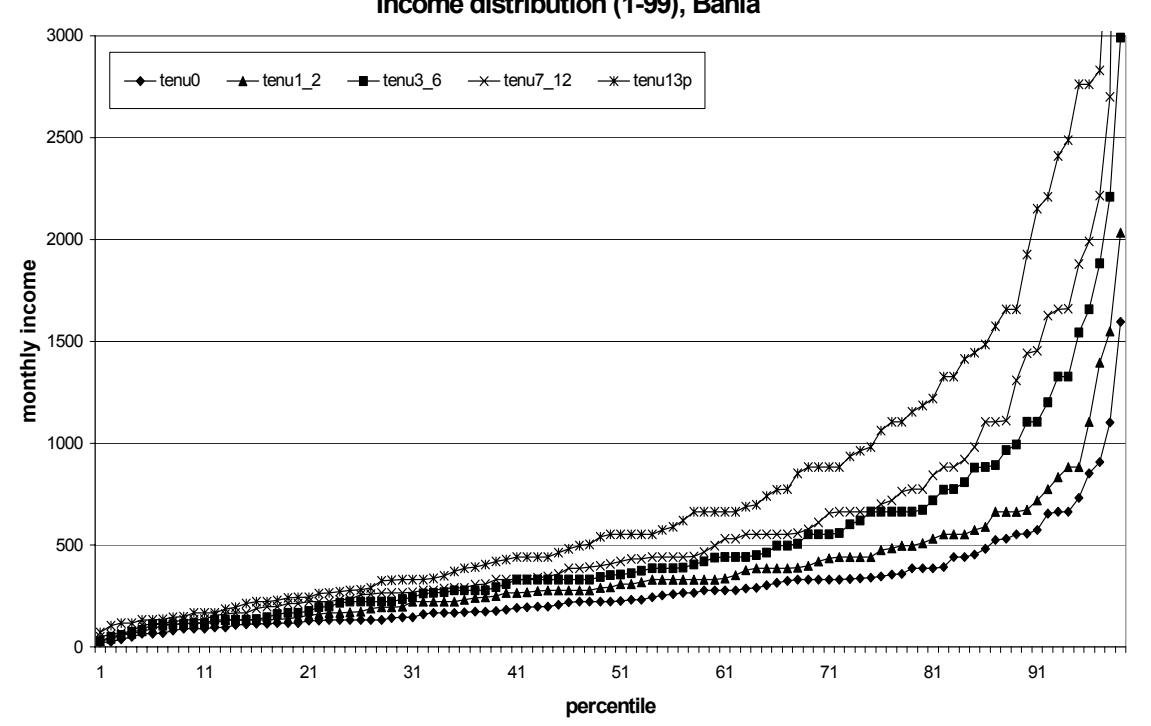

Income distribution (1-99), North-East
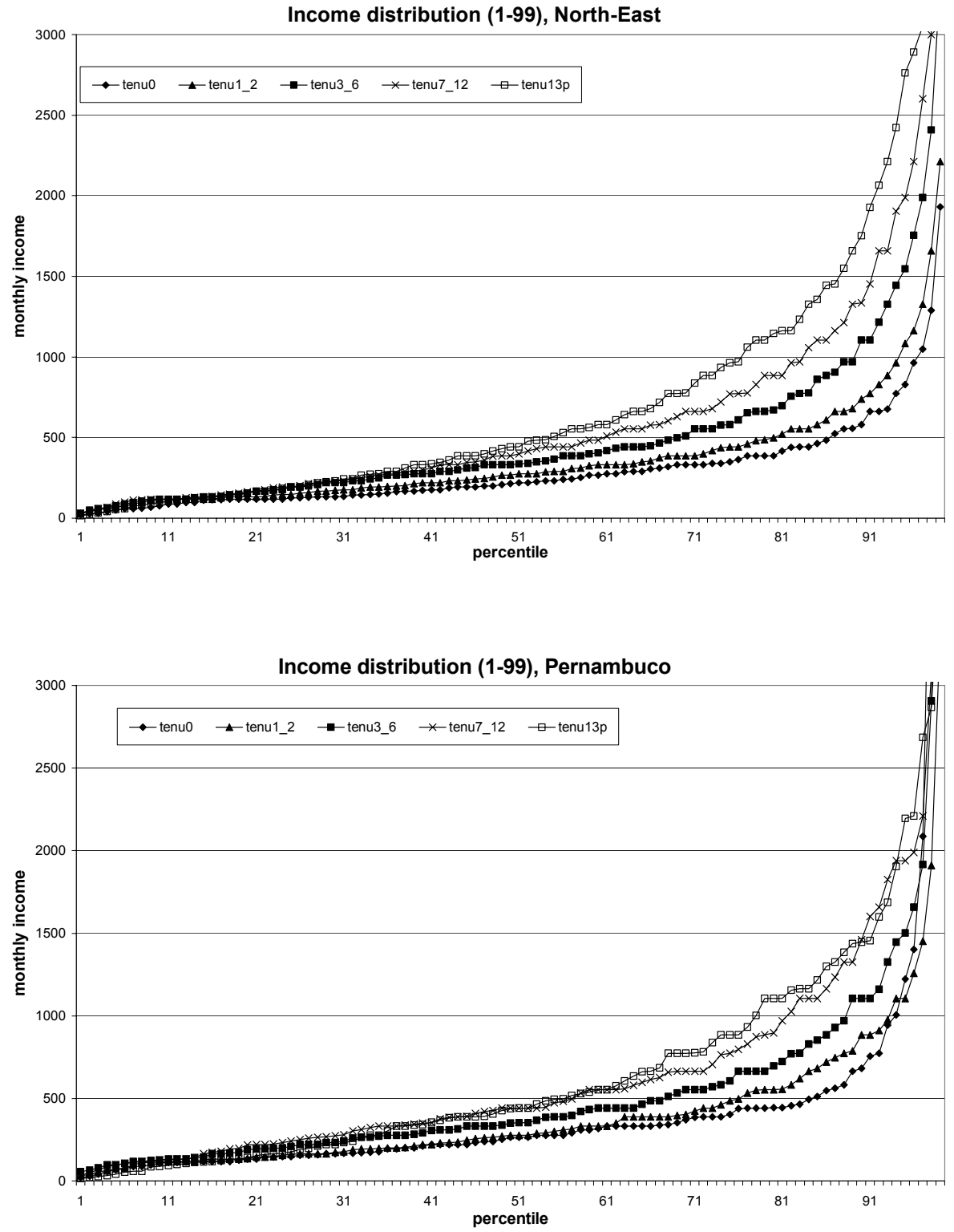


\section{FIGURE 2A, CONTINUED}

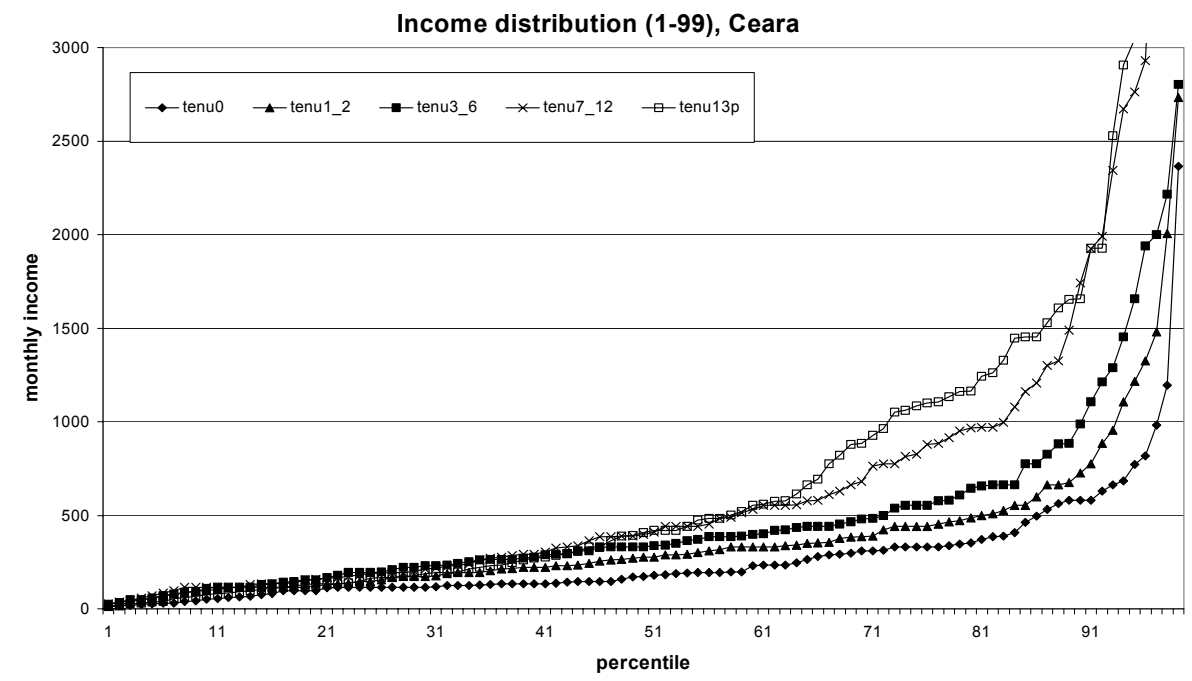


Figure 3A. Income distribution, age groups
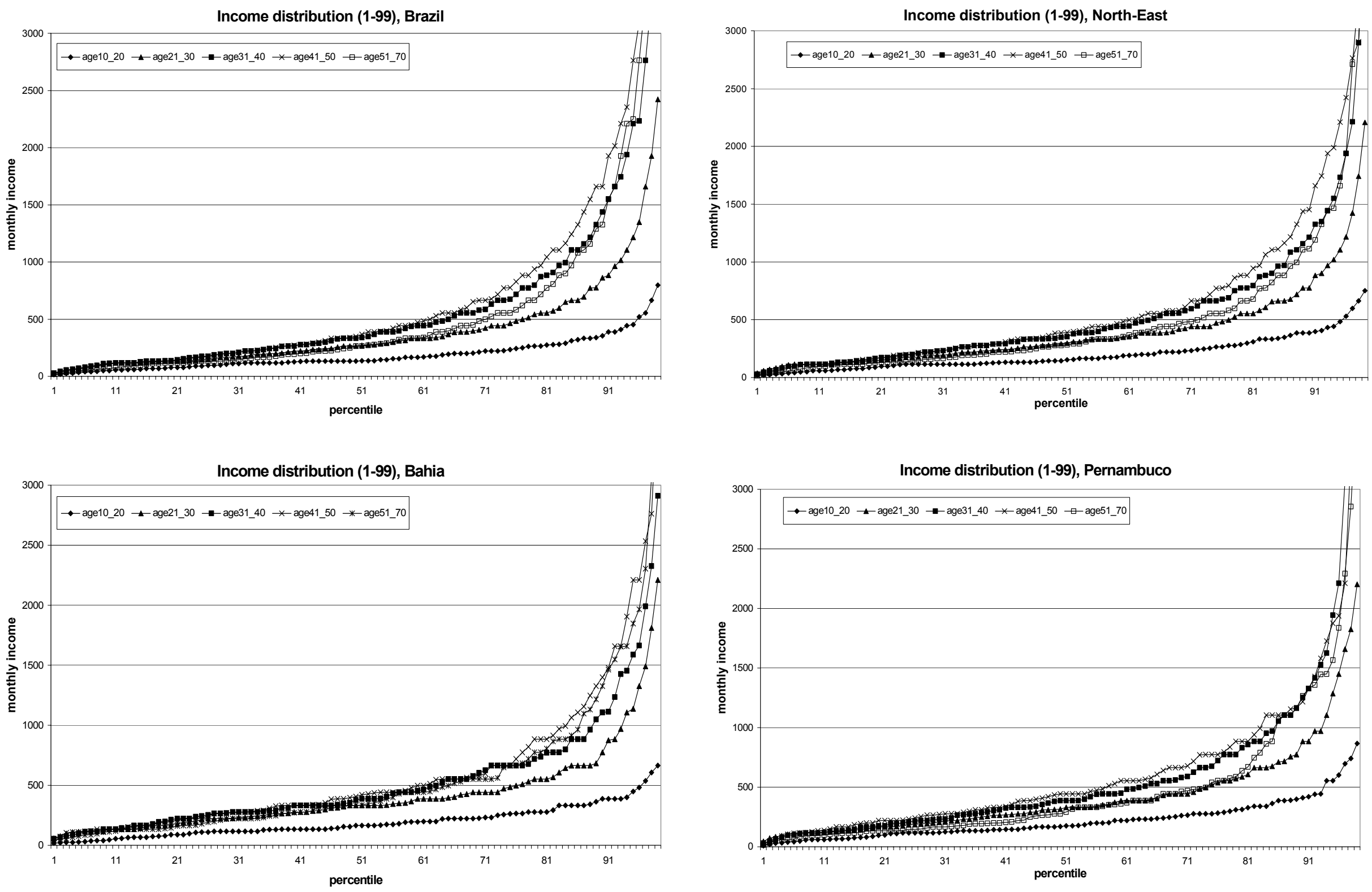

71 
7. FIGURE 3A, CONTINUED

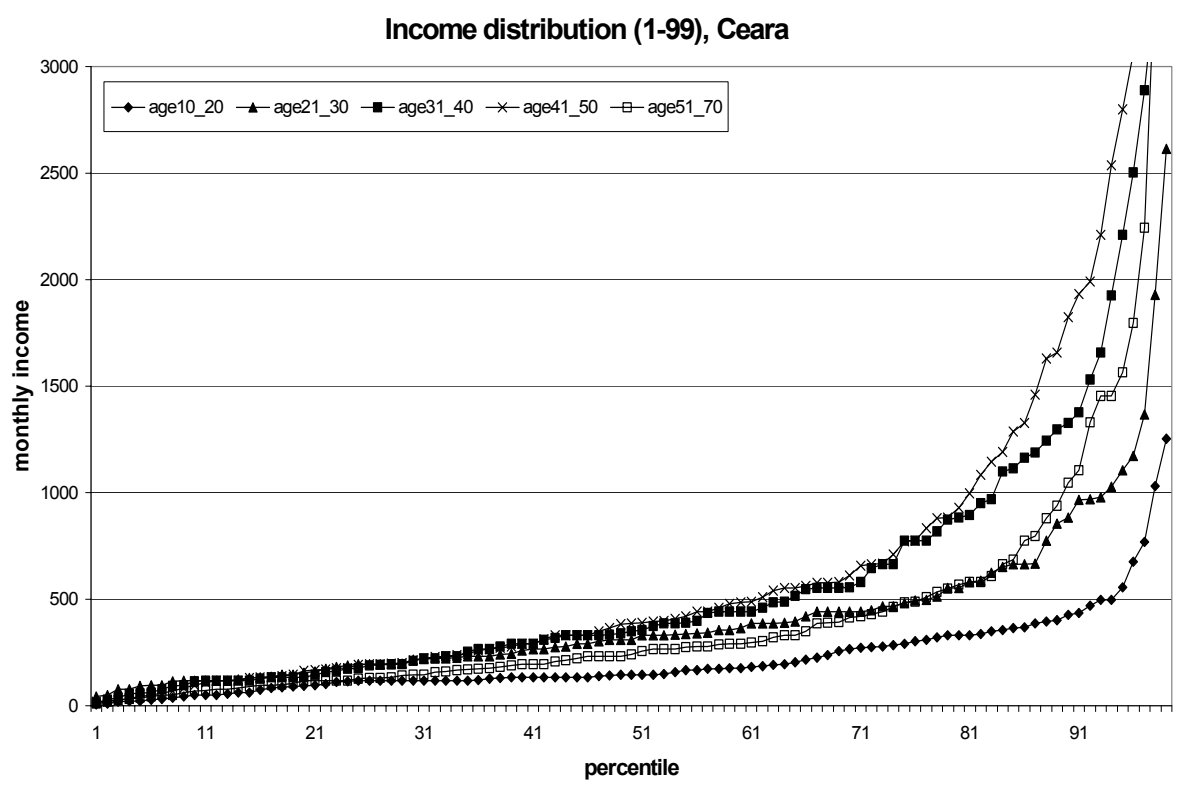

72 
Figure 4A. Income distribution, educational groups
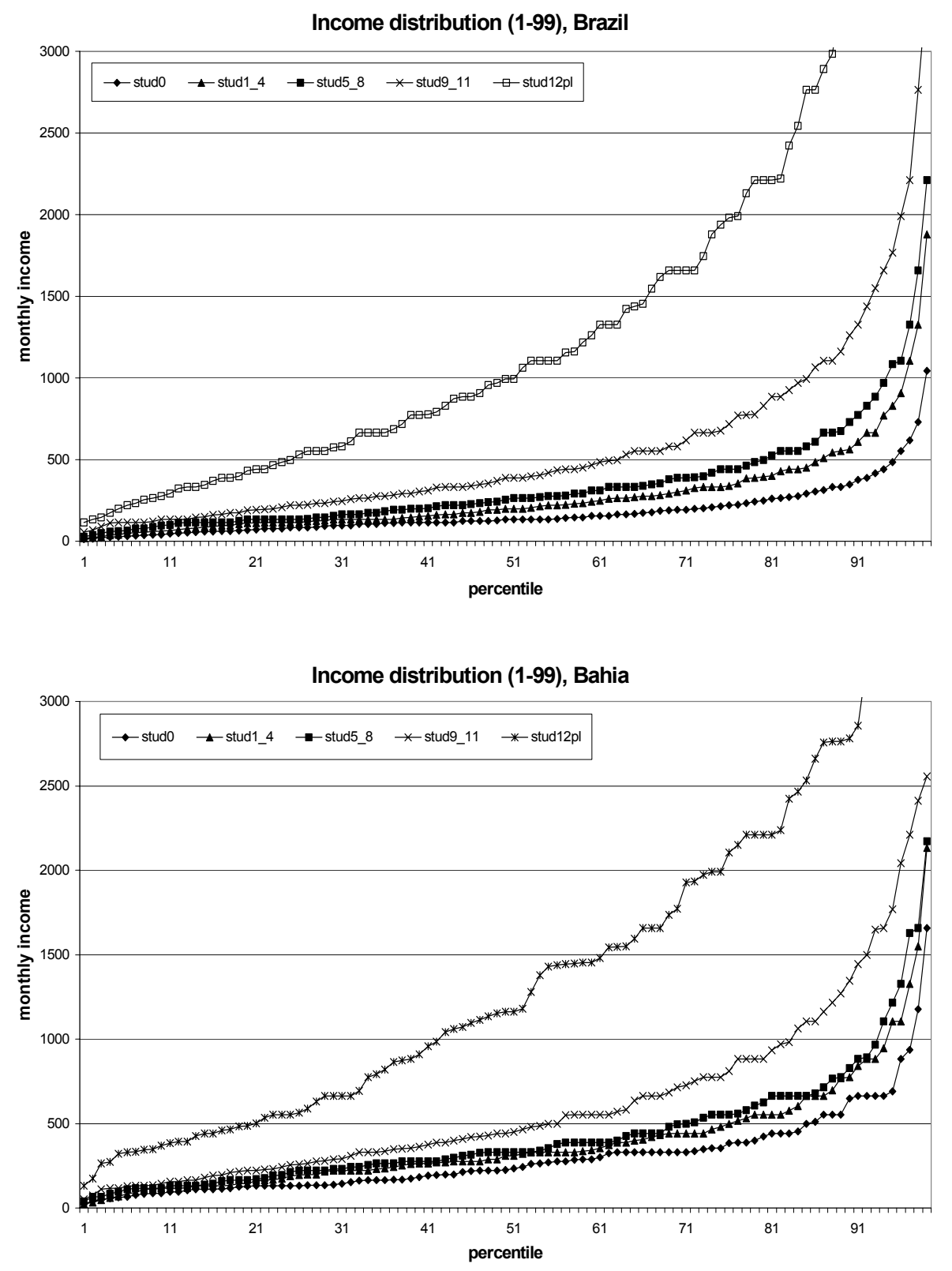

Income distribution (1-99), North-East
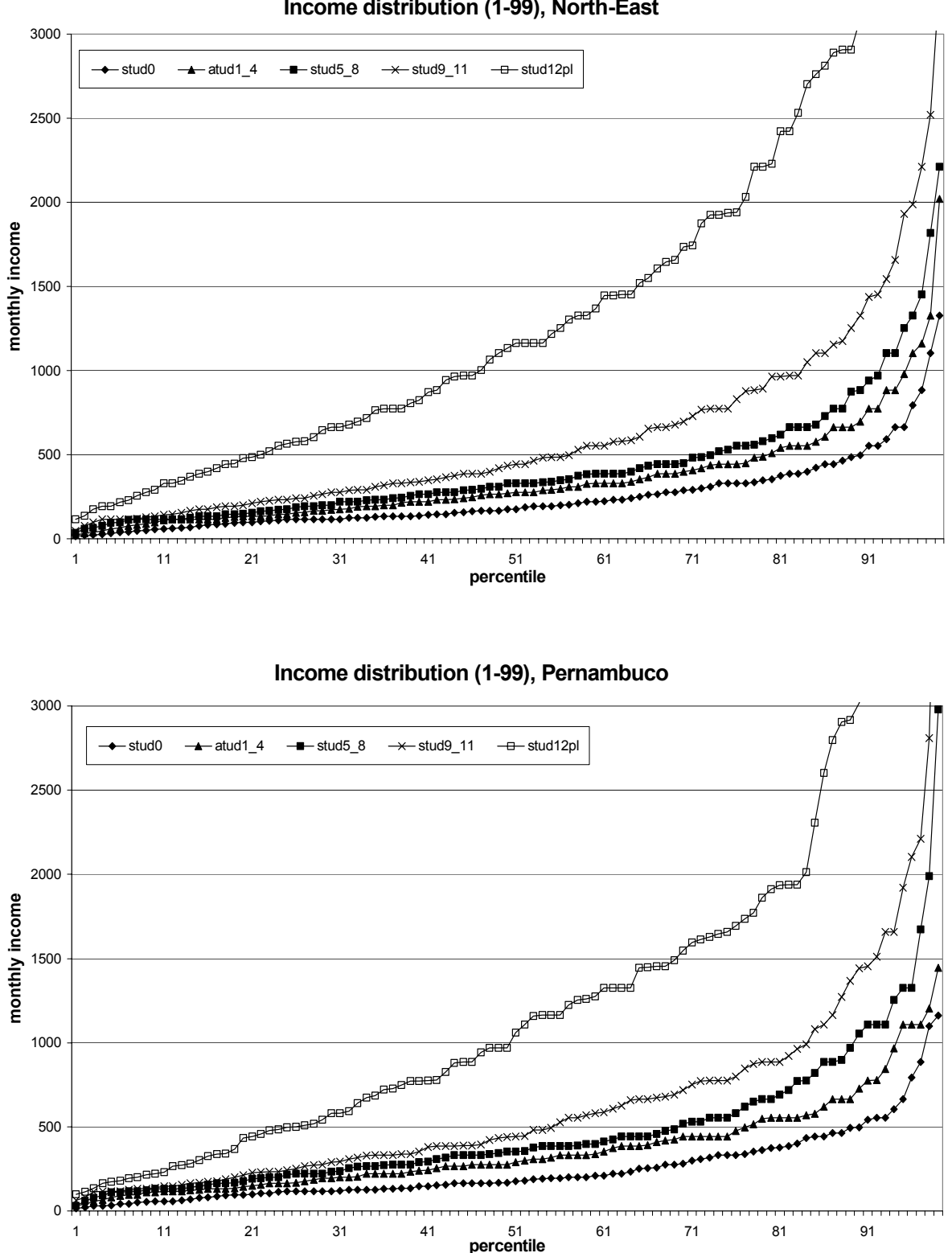


\section{FIGURE 4A, CONTINUED}

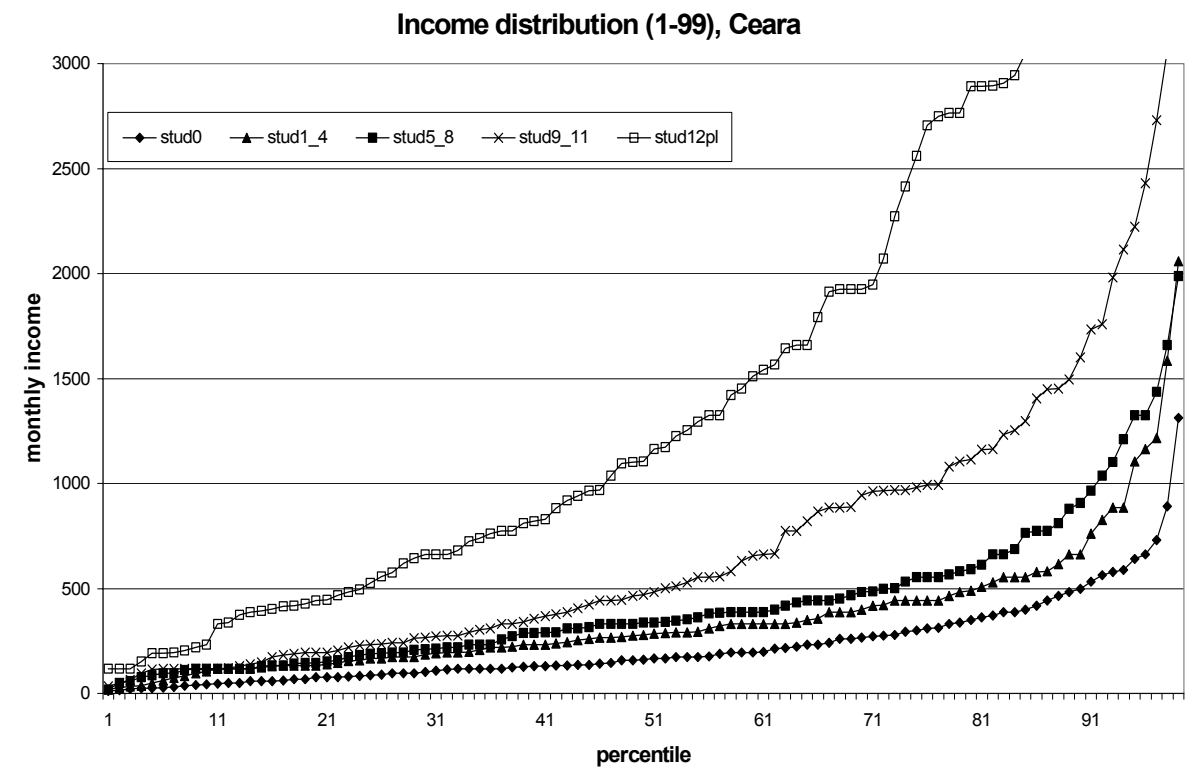


Figure 5A. Income distribution, union-nonunion groups

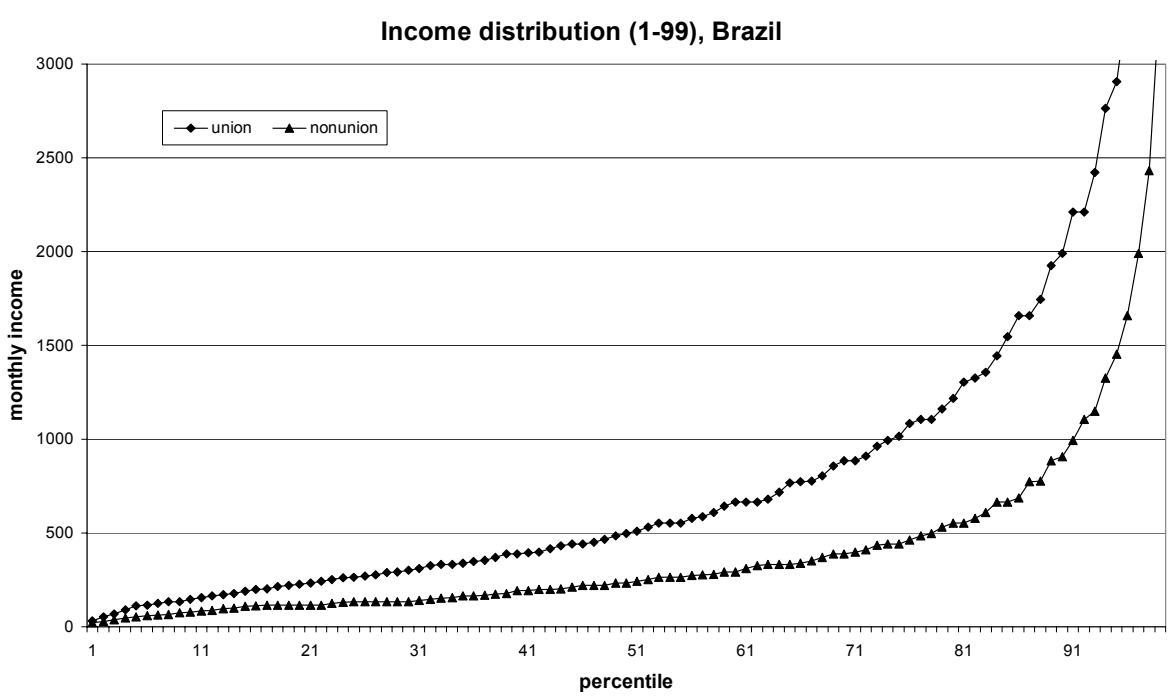

Income distribution (1-99), Bahia

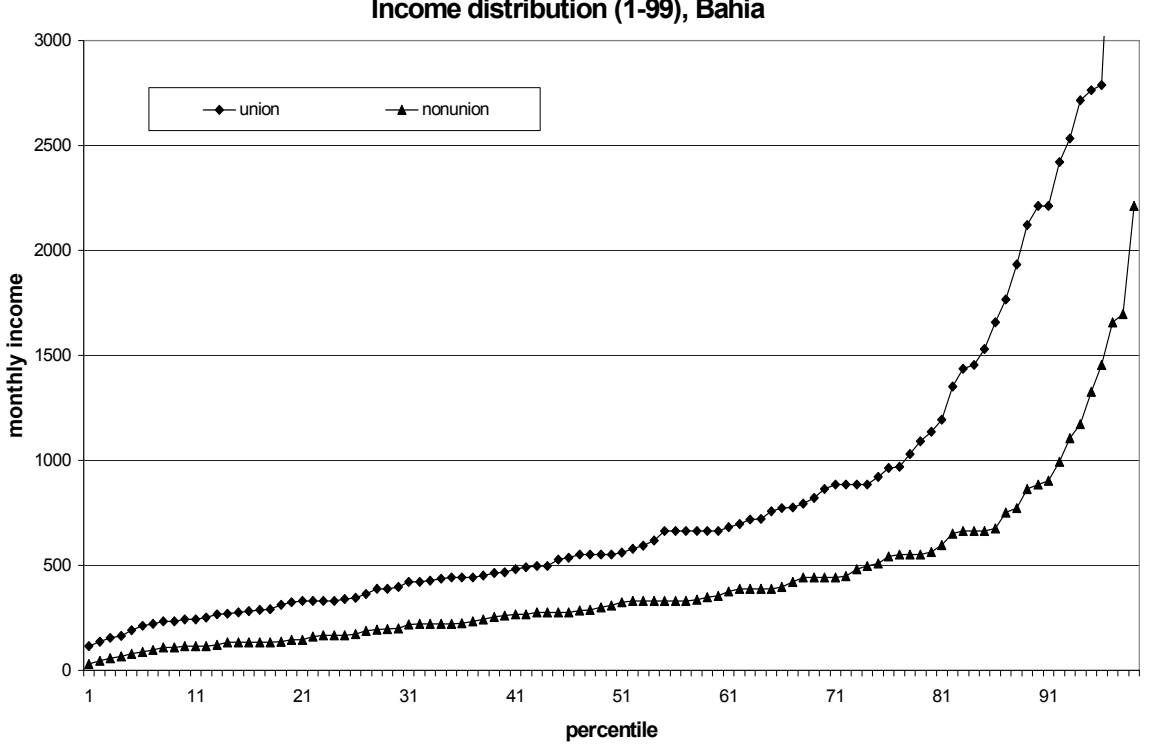

Income distribution (1-99), North-East

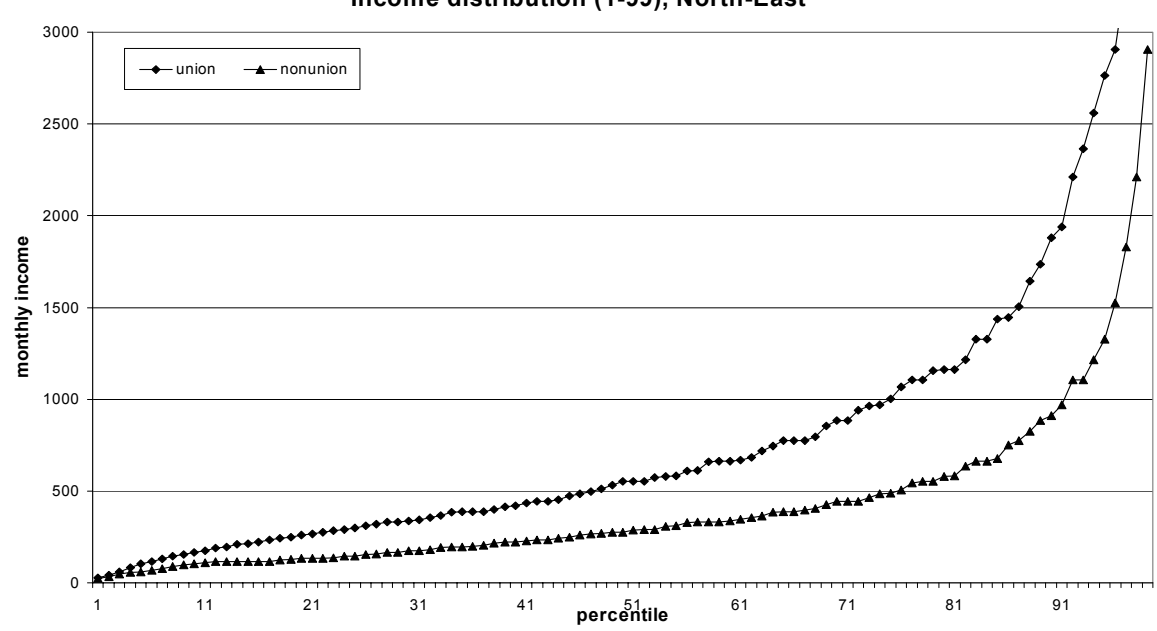

Income distribution (1-99), Pernambuco

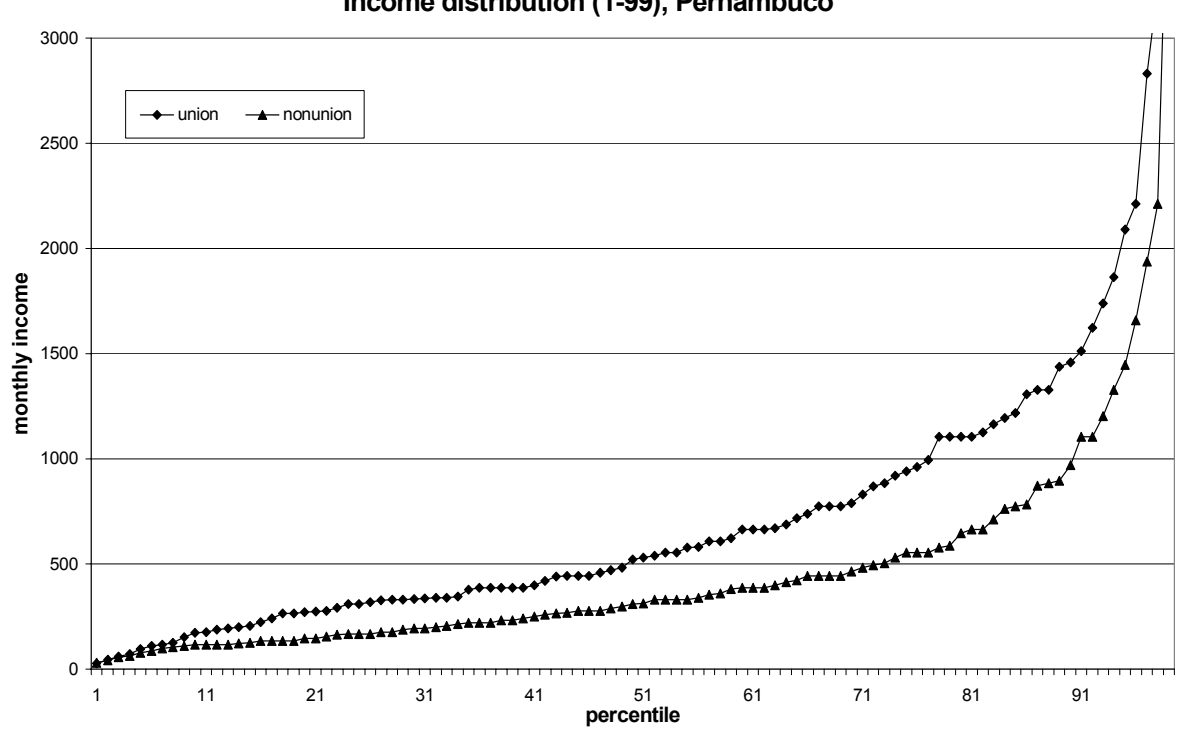




\section{FIGURE 5A, CONTINUED}

Income distribution (1-100), Pernambuco

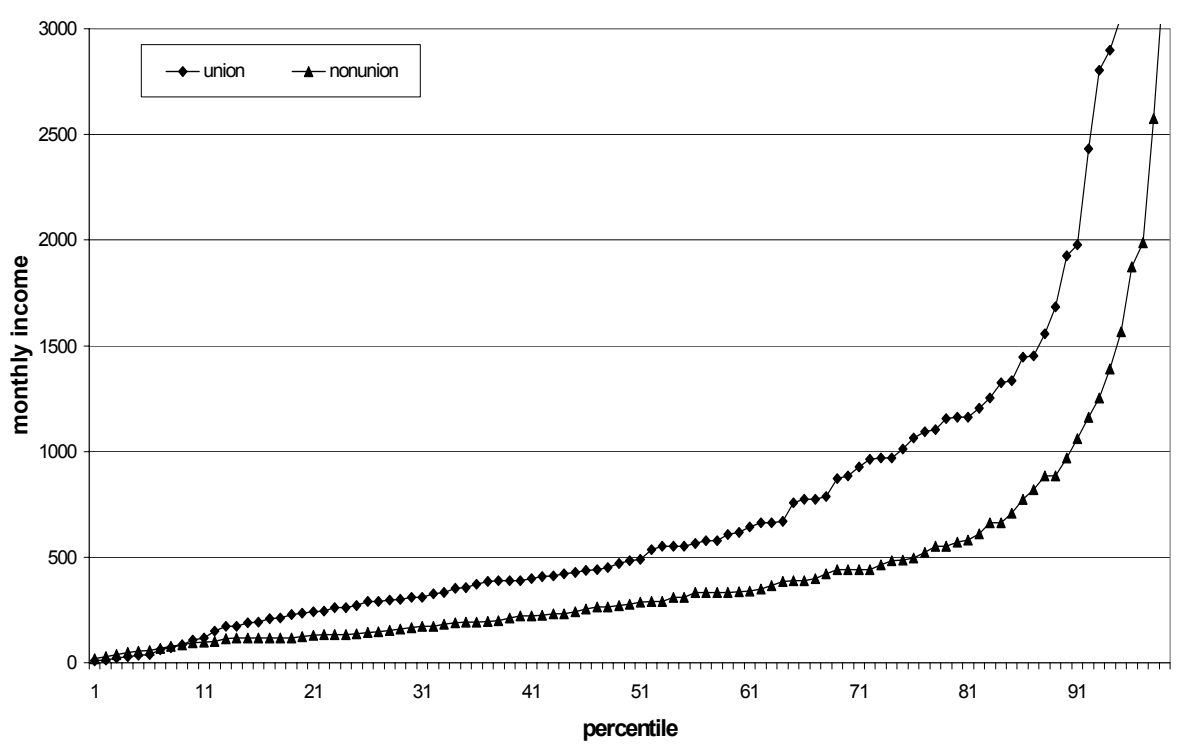


Figure 6A_1 Sectors (detailed)

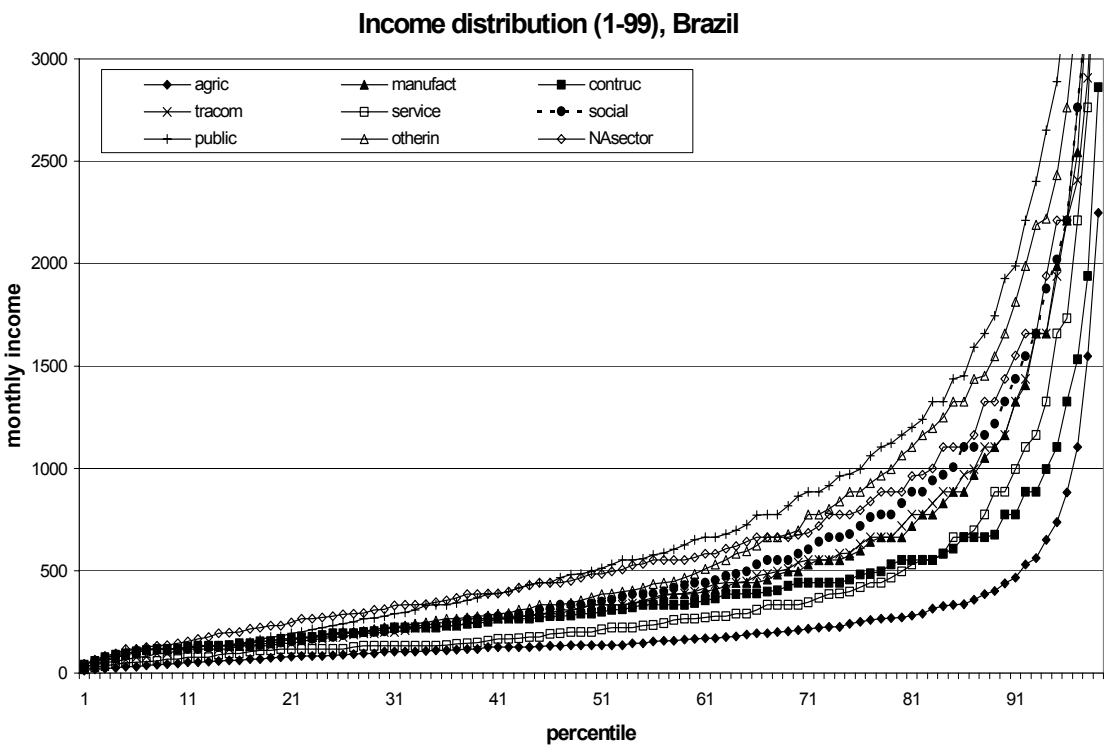

Income distribution (1-99), Bahia

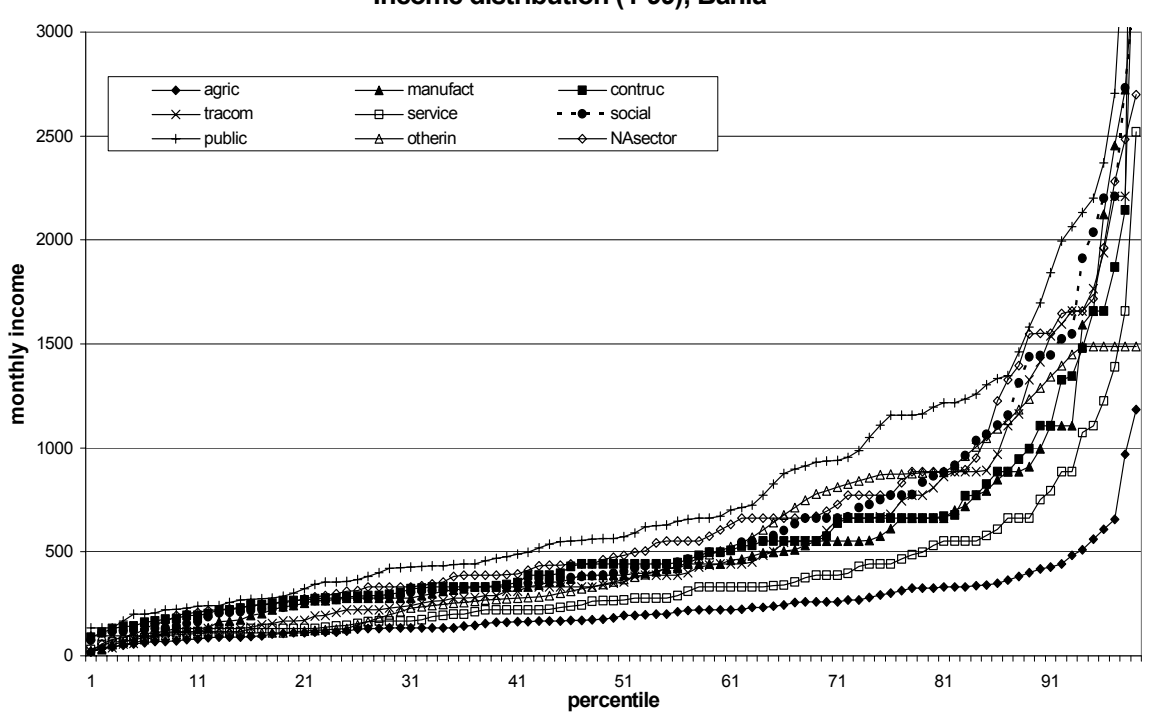

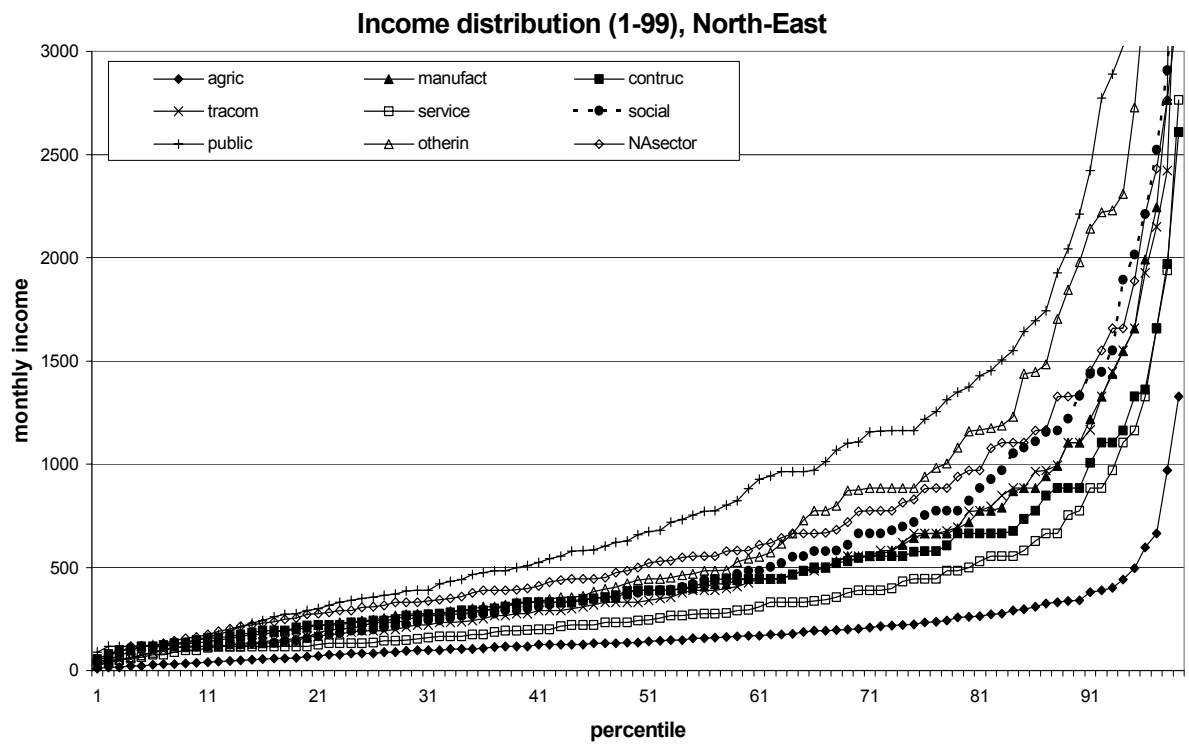

Income distribution (1-99), Pernambuco

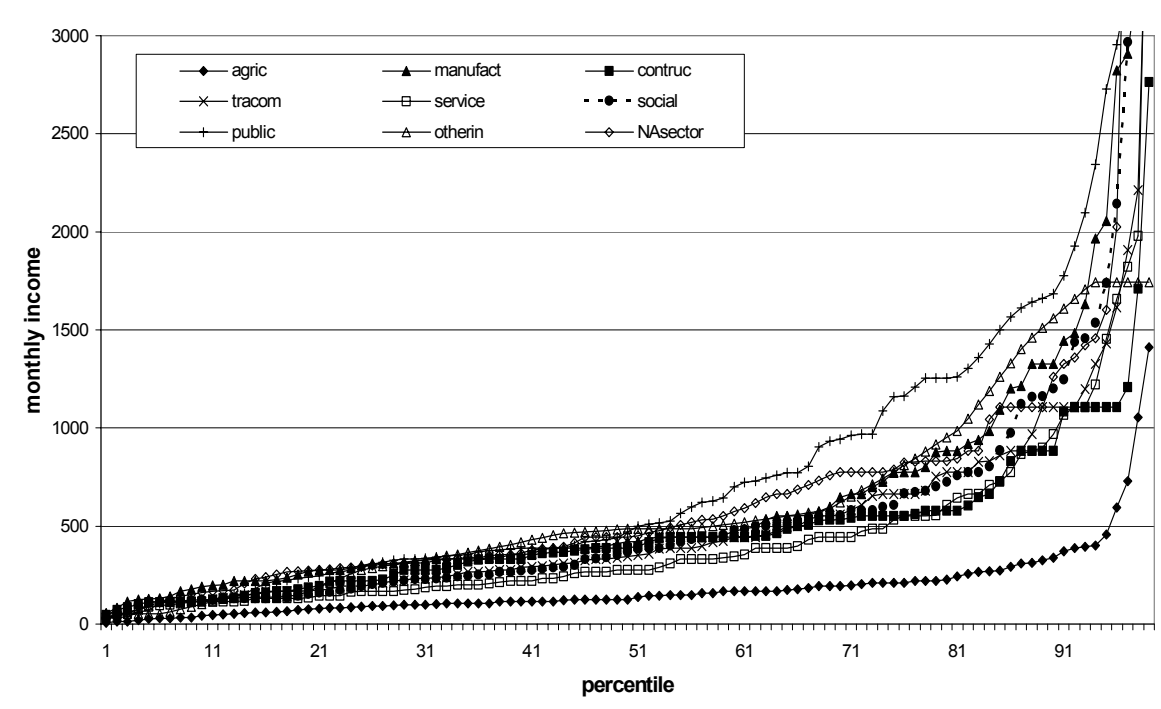


Figure 6A_2. Sectors (aggregated)
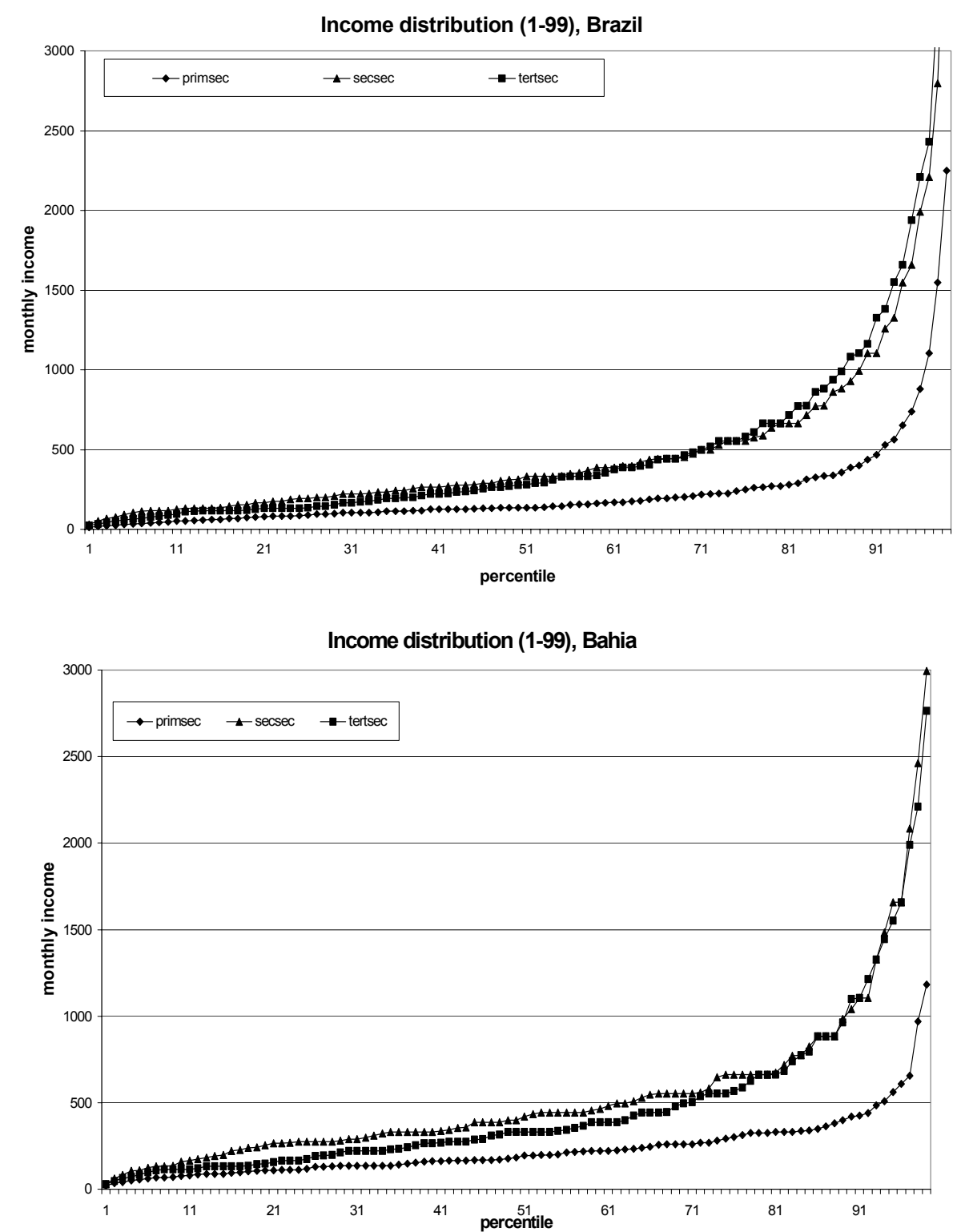

Income distribution (1-99), North-East
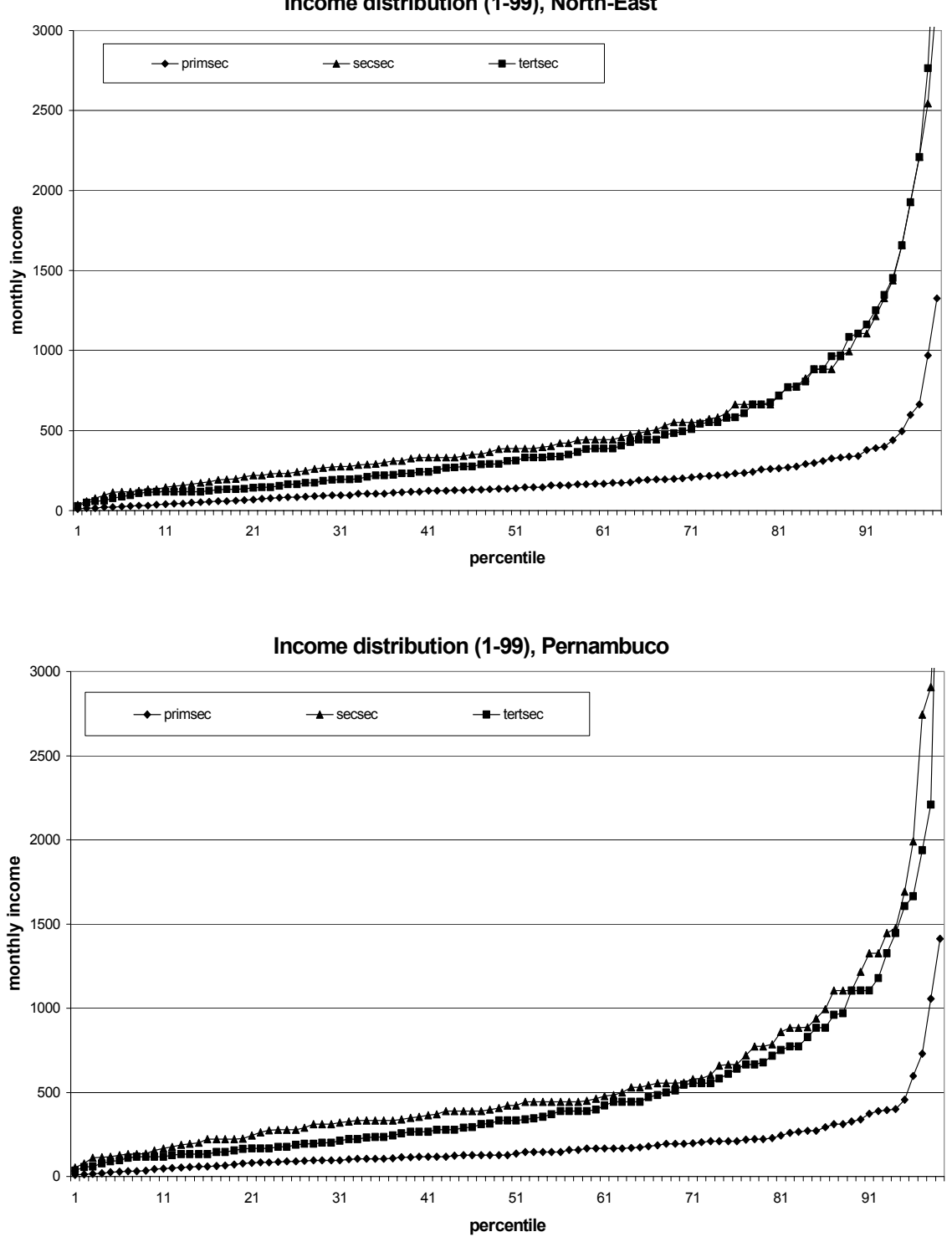
10. FIGURE 7A. INCOME DISTRIBUTION, MARRIED-NONMARRIED GROUPS
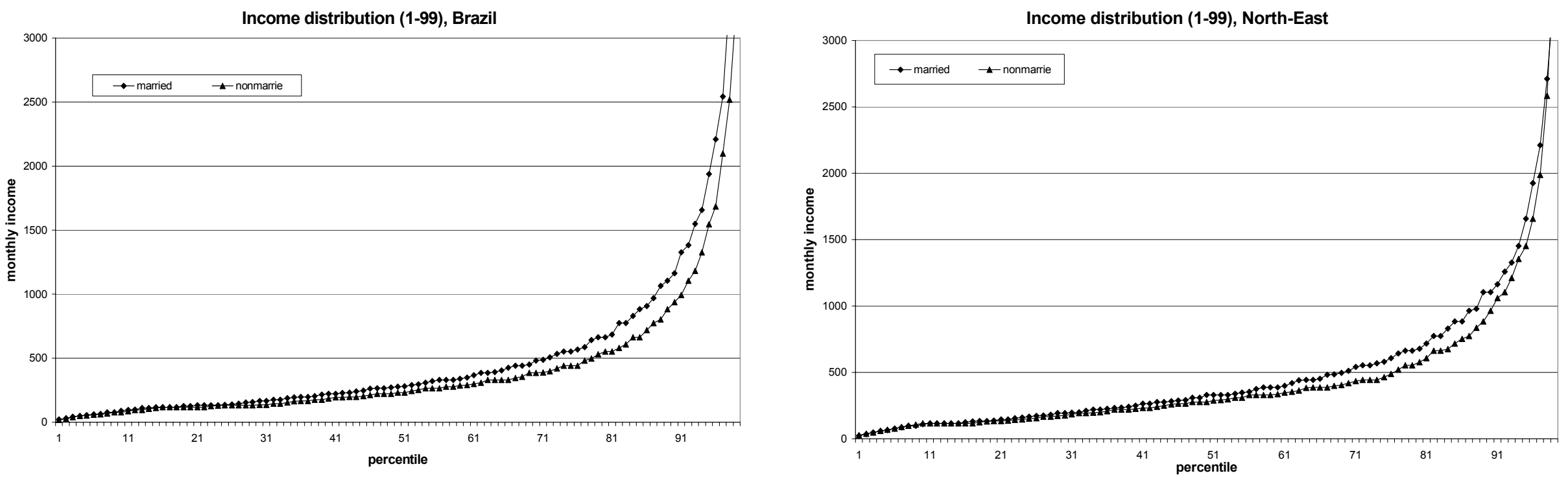

79 

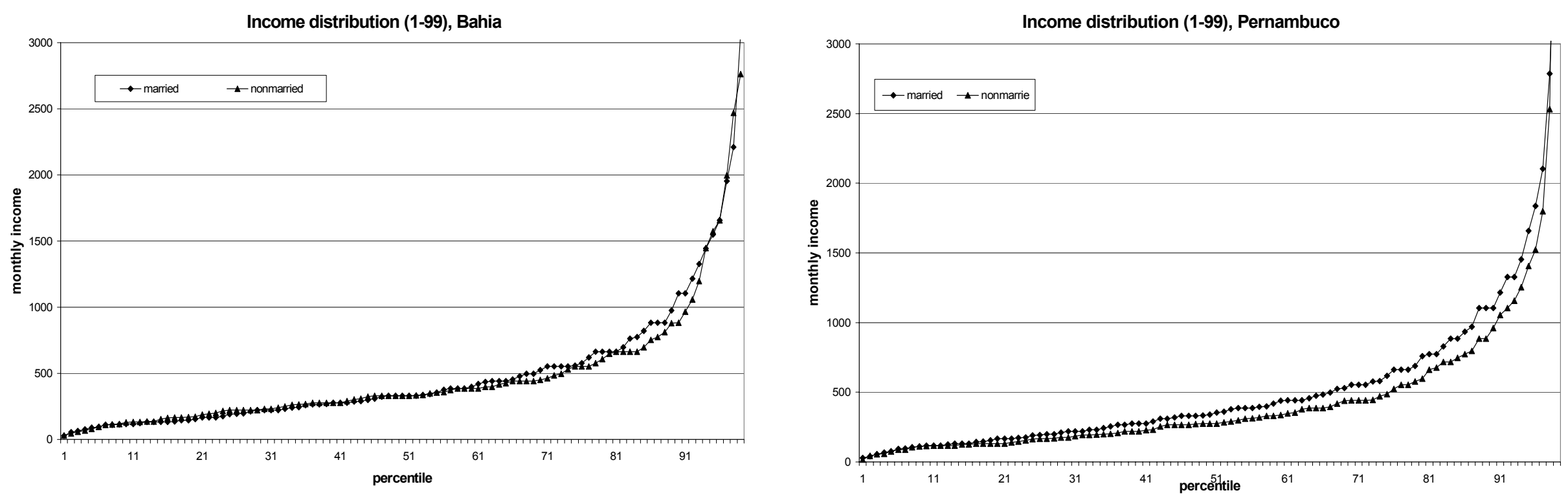
11. FIGURE 7A, CONTINUED

Income distribution (1-99), Ceara

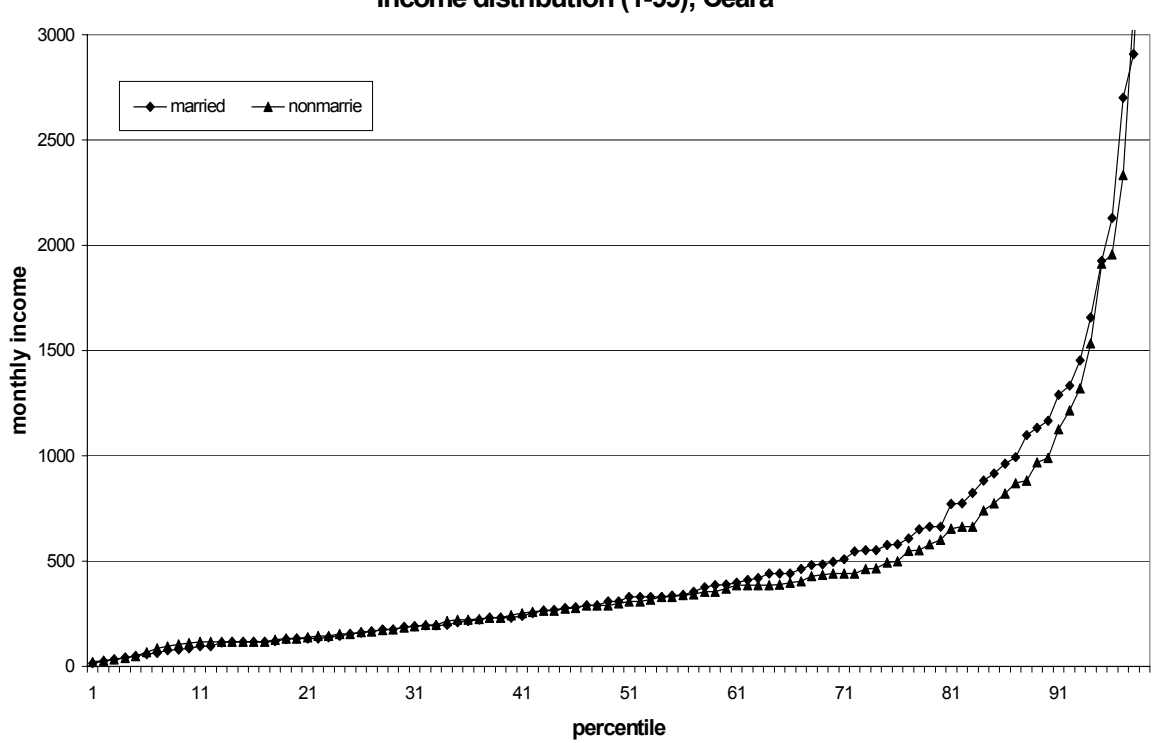


Figure 8A. Income distribution, child-family vs. non-child-family groups
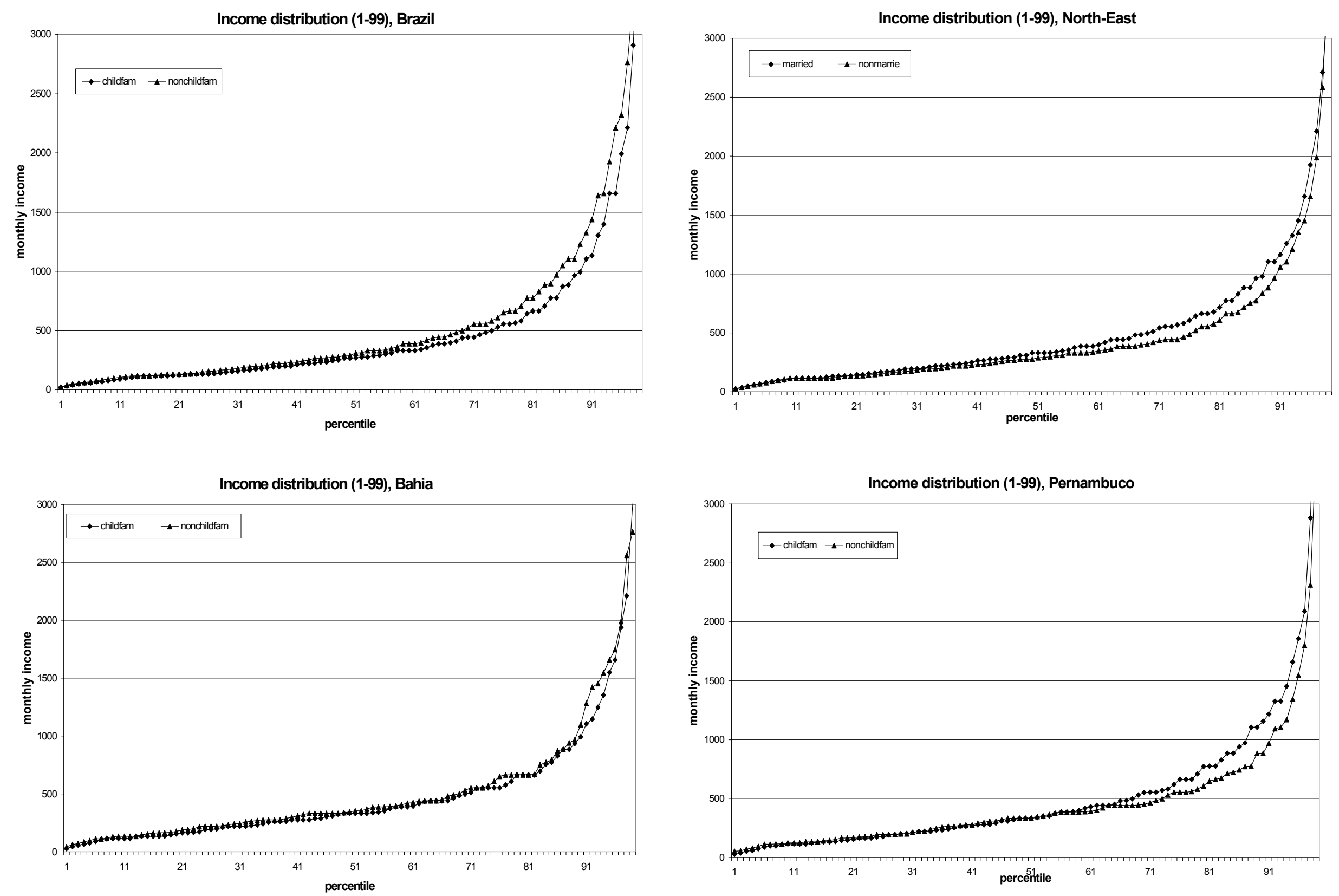


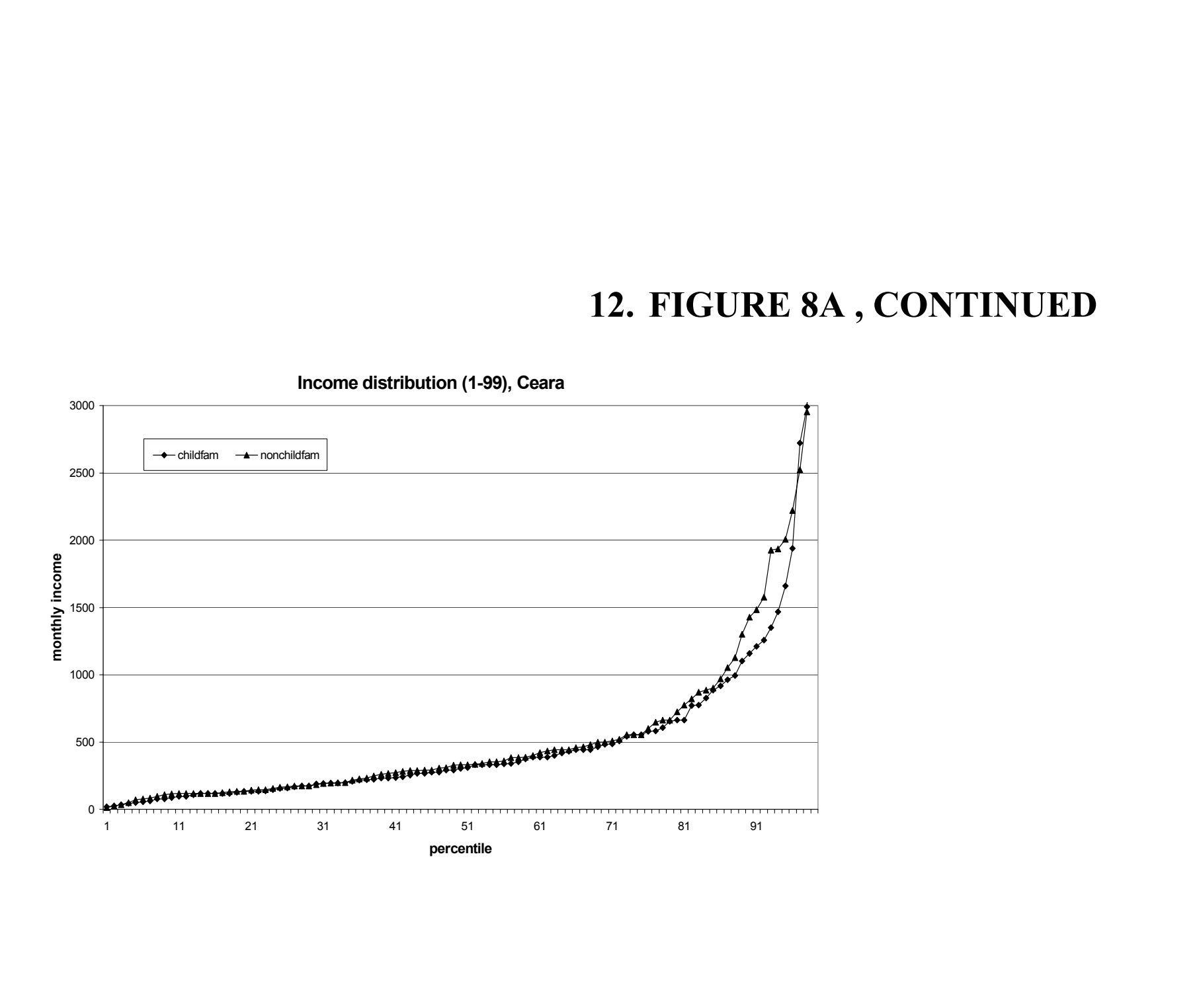




\section{Figure 9A. Income distribution, gender groups}

Income distribution (1-99), Brazil

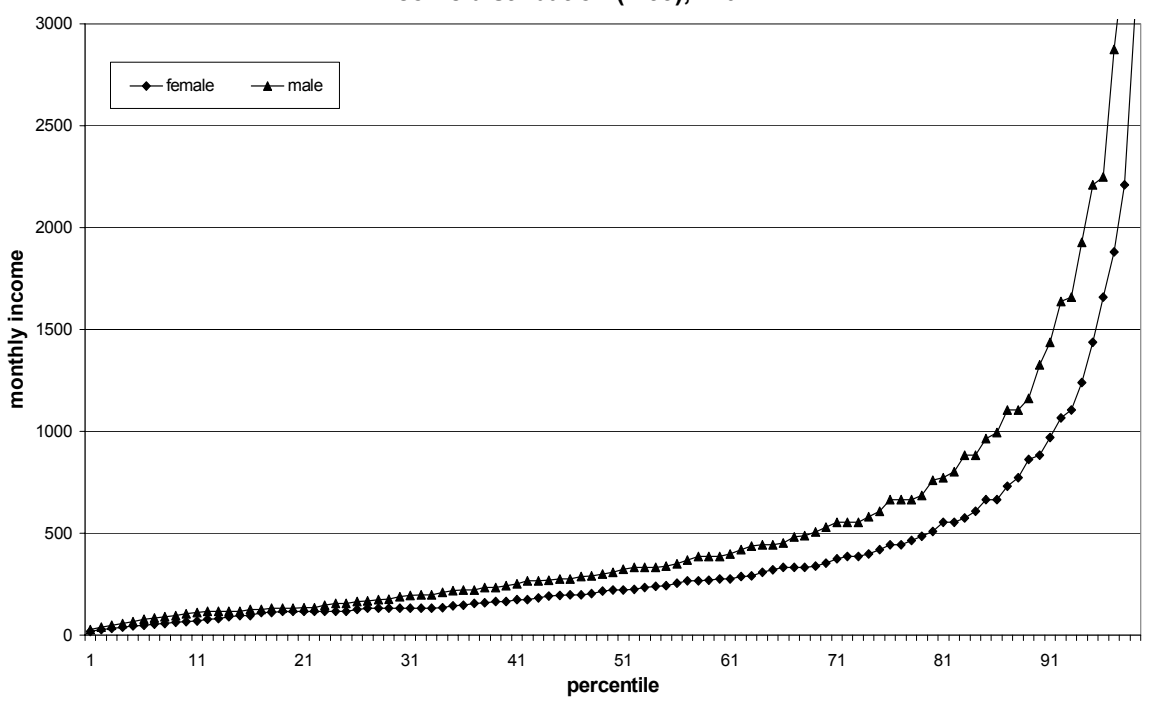

Income distribution (1-99), Bahia

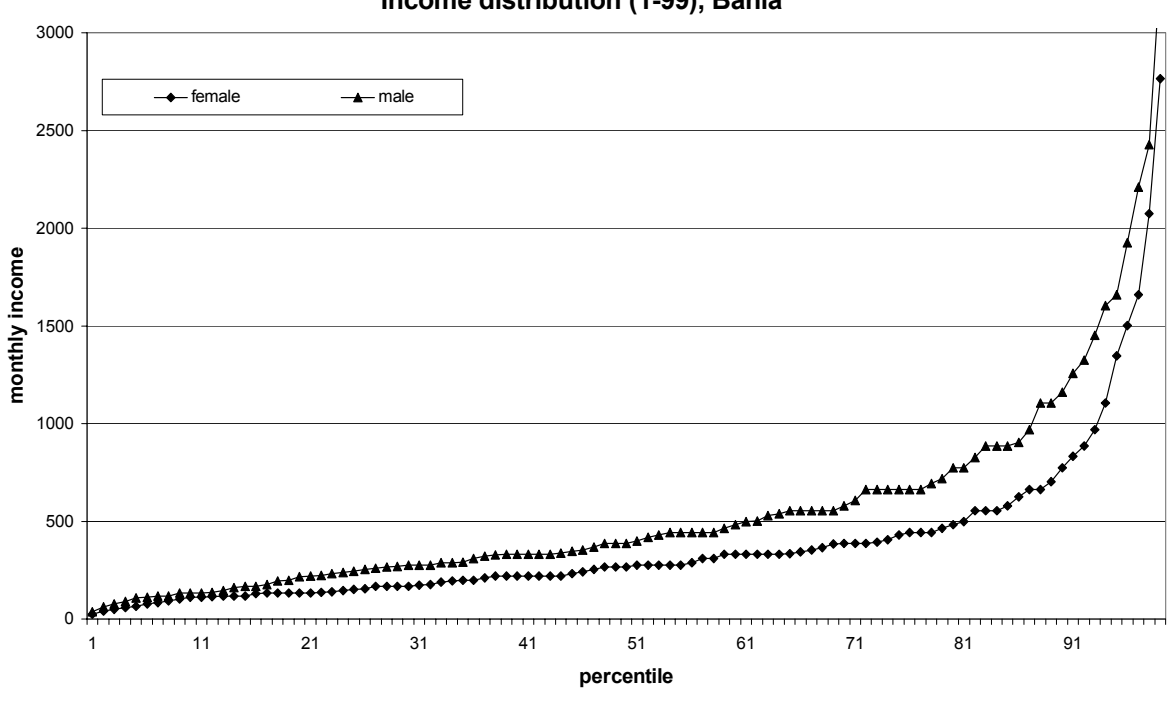

Income distribution (1-99), North-East

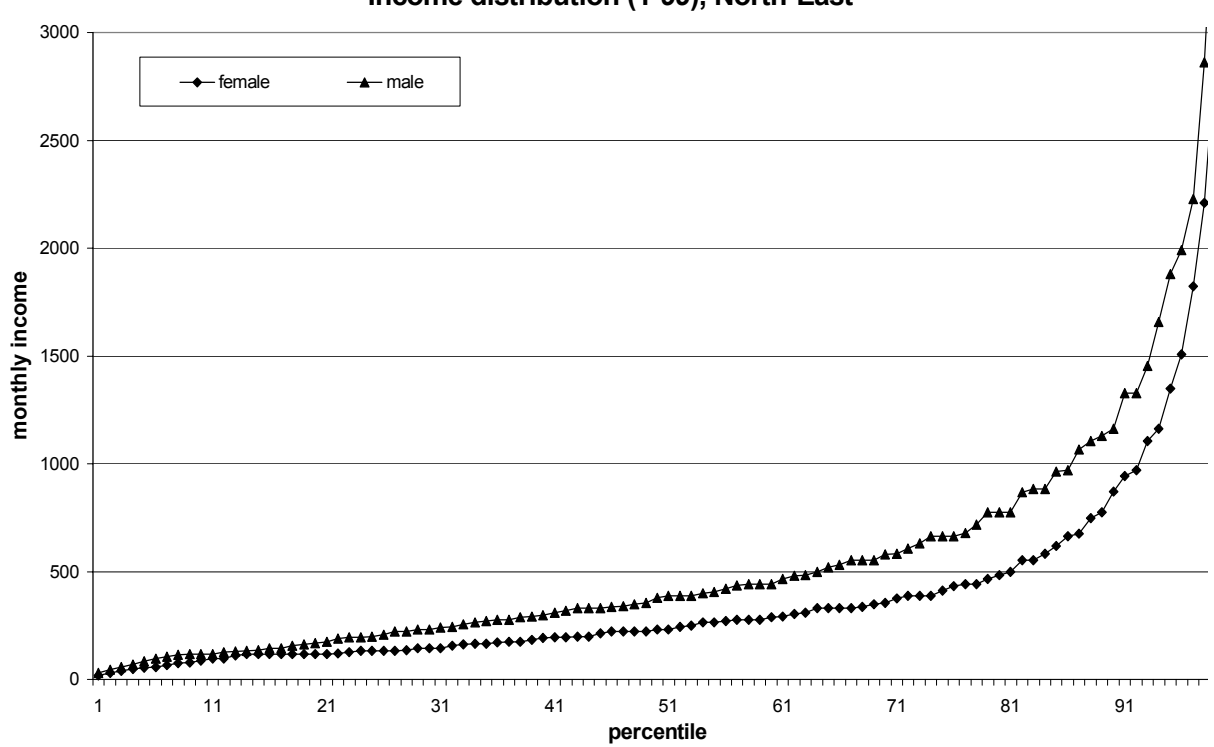

Income distribution (1-99), Pernambuco

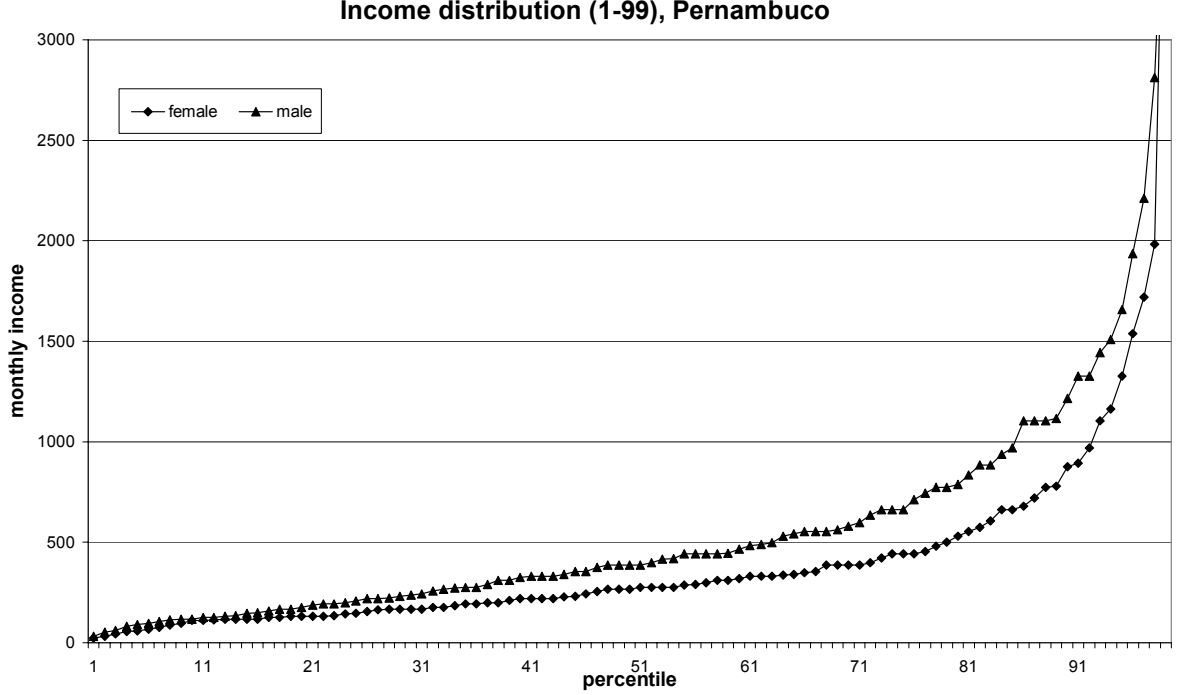




$$
\sigma
$$


Figure 10A. Income distribution, race/ethnicity groups
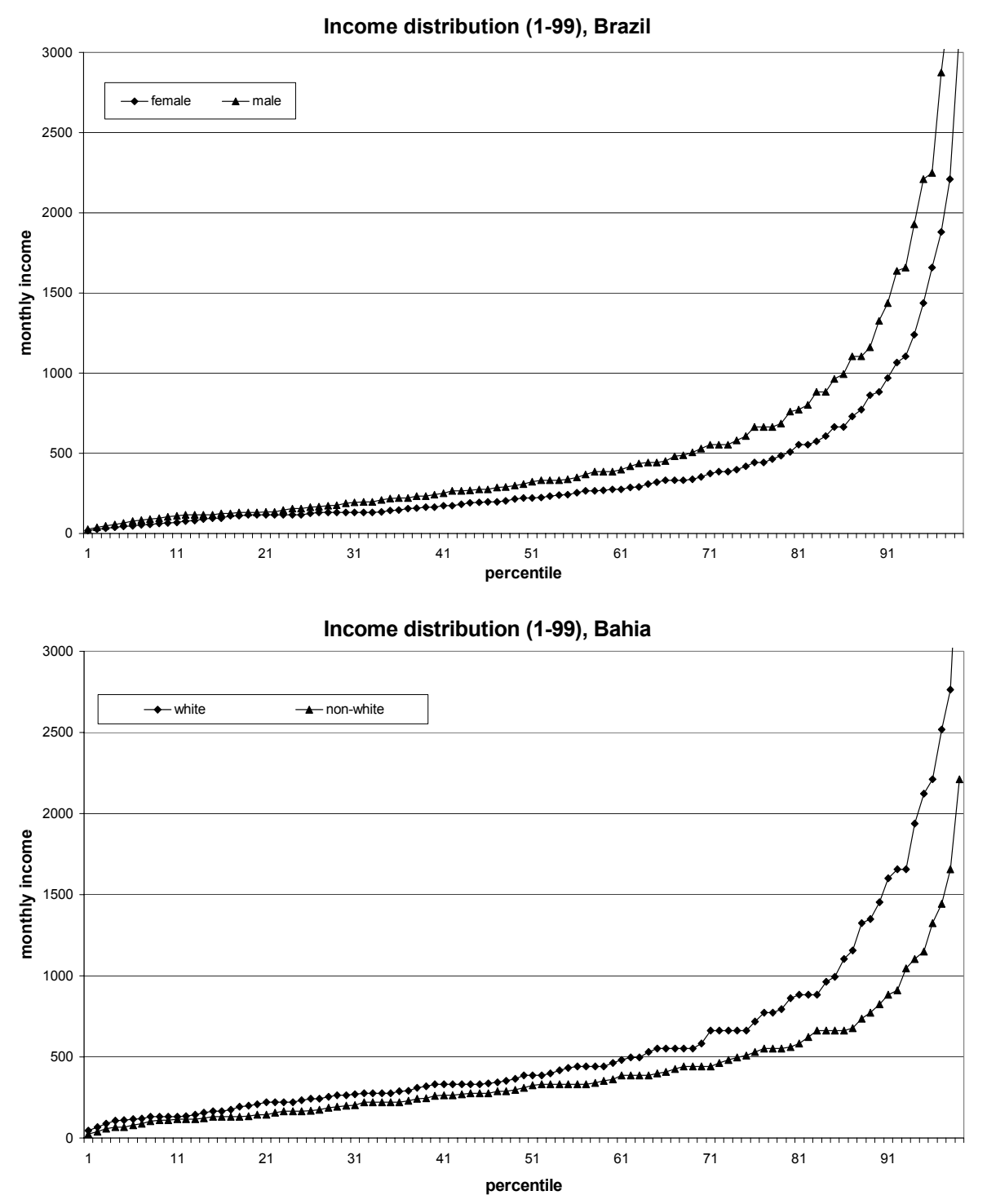

Income distribution (1-99), North-East
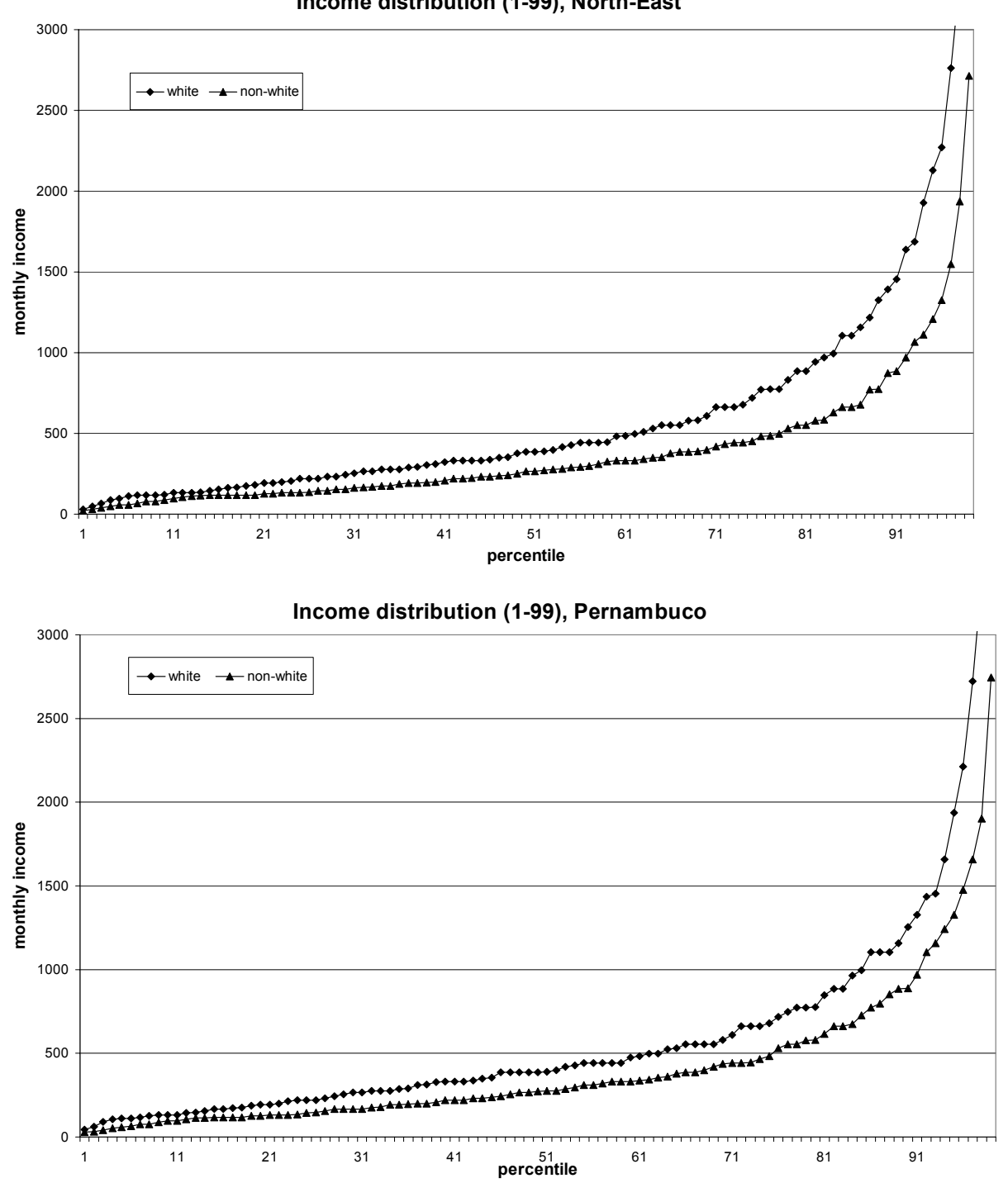
WB105749

C: $\backslash$ a- word $\backslash m y$ papers $\backslash$ Northeast labor markets $\backslash$ Northeast labor markets-WP June 22.doc

June 22, 2004 1:10 PM 